\title{
The Proven Key: Roles and Rules for Dictionaries in the Patent Office and the Courts
}

Joseph Scott Miller

University of Georgia School of Law, getmejoe@uga.edu

James A. Hilsenteger

p bepress SSRN

\section{Repository Citation}

Joseph Scott Miller and James A. Hilsenteger, The Proven Key: Roles and Rules for Dictionaries in the Patent Office and the Courts (2005),

Available at: https://digitalcommons.law.uga.edu/fac_artchop/782

This Article is brought to you for free and open access by the Faculty Scholarship at Digital Commons @ University of Georgia School of Law. It has been accepted for inclusion in Scholarly Works by an authorized administrator of Digital Commons @ University of Georgia School of Law. Please share how you have benefited from this access For more information, please contact tstriepe@uga.edu. 


\title{
ARTICLE
}

\section{THE PROVEN KEY: \\ ROLES AND RULES FOR DICTIONARIES AT THE PATENT OFFICE AND THE COURTS}

\author{
JOSEPH SCOTT MILLER* \\ JAMES A. HILSENTEGER ${ }^{* *}$
}

\section{TABLE OF CONTENTS}

Introduction

I. The Rise and Rise of Dictionaries at the Federal Circuit ........838

A. The Top-Level View of Dictionary Citation Rates in

Patent Cases

1. Comparing the pre- and post-Markman eras...............845

2. Annual dictionary citation rates from 1993 to $2003 \ldots .847$

B. "Unbiased Reflections of Common Understanding" .......851

1. Markman $v$. Westview Instruments

2. Vitronics Corp. v. Conceptronic, Inc.

3. Texas Digital Systems, Inc. v. Telegenix, Inc

C. The Federal Circuit's Use of Dictionaries for Claim Construction

Assistant Professor, Lewis $\mathcal{F}^{2}$ Clark Law School. We wrote this Article with the support of a Summer Research Grant from Lewis $\mathcal{E}$ Clark Law School, as well as the benefit of comments at the Lewis $\mathcal{F}^{2}$ Clark Law School Faculty Colloquium, the Spring 2004 Intellectual Property Workshop Series at George Washington University Law School, the Spring 2004 meeting of the Oregon Patent Law Association, and the 4th Annual Intellectual Property Scholars Conference at DePaul. Comments from Bob Brauneis, Dean Dunlavey, John Duffy, Ben Hattenbach, Laura Heymann, Clarissa Long, Lydia Loren, Kimberly Moore, Lisa Schneider, and Polk Wagner were especially helpful. Jermaine Grubbs and Alex Ortiz provided able research assistance in the early stages of this project. The authors would welcome comments on this Article at jsmiller@lclark.edu. P.C.

J.D. 2004, Lewis $\mathcal{F}^{\circ}$ Clark Law School. Associate, Marger Johnson \& McCollom,

The views expressed herein are those of the authors, not their employers or clients. Not yet, anyway. 
1. Methodology

2. Results

II. Bias Through the Back Door? Dictionary Selection at Court

A. Dictionary Choice Unchained-The Dark Side of

Telegenix....

B. The Difference a Different Dictionary Can Make

1. The usage note case

2. The high frequency and wood board cases:

Making one from many

III. Moving Dictionary Choice to the Patent Office

A. Patent Office Power Over Dictionary Choice

B. There's No Time Like the Filing Date

C. Changing Patent Office Rules to Regularize Dictionary

Choice

1. Changing the application content rule to require dictionary selection

2. Changing examiner practice to require dictionary identification.

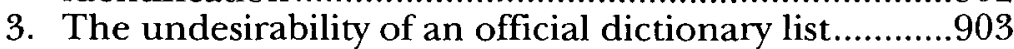

Conclusion .904

Postscript: The Decision in Phillips v. AWH Corp................................905

Appendix A

Appendix B

.913

Appendix C

\section{INTRODUCTION}

New law students often experience a kind of culture shock. A bit of this shock comes from the flurry of unfamiliar words and phrases that students confront in most every class-assumpsit, bill of attainder, demurrer, easement, ex post facto law, seisin, trover. Another share comes from seeing more familiar words used in new ways-bond, consideration, covenant, release, servitude. Law professors tell students, especially in those rocky first few weeks of first year classes, to "look it up!" Look it up in Black's Law Dictionary, or Bouvier's Law Dictionary... just look it up.'

Law professors thus follow the tradition of teachers generally, who help students fully join a language community by urging them to consult an exhaustively researched, carefully constructed repository of the range of ordinary meanings of words in that community-in other words, a dictionary. And in this exchange both teachers and students reflect and reinforce the "reverence for dictionaries" that is

1. For an engaging account of Bouvier's decline and Black's ubiquity, see Mary Whisner, Bouvier's, Black's, and Tinkerbell, 92 LAw LIBR.J. 99 (2000). 
"deeply embedded in our culture." Indeed, dictionaries can be powerful symbols of cultural accomplishment and belonging. Consider, for example, the ad copy that accompanied the 1961 launch of Webster's Third New International Dictionary, still one of the leading unabridged dictionaries of the English language: "Hold the English language in your two hands," embodied by a copy of Webster's Third, "and you possess the proven key to knowledge, enjoyment, and success!"

If judicial behavior is any indication, dictionary formulations of ordinary meanings not only mark common ground in a language community, they also play a prominent role in officially stated justifications for legal judgments. The U.S. Supreme Court, setting the tone for the national judiciary, continues to quote extensively from both law dictionaries and general purpose English language dictionaries in its opinions. In the October $2003 \mathrm{Term}$, for example, seven majority opinions $(9.6 \%)$ from among the Court's seventythree cases with full opinions ${ }^{4}$ use one or more dictionaries to justify the chosen construction of a disputed statute, ${ }^{5}$ constitutional provision, ${ }^{6}$ or other binding legal text. ${ }^{7}$ Nor is the October 2003

2. Lawrence Solan, When Judges Use the Dictionary, 68 AM. SPEEcH 50, 50 (1993). Professor Solan, a law professor with a $\mathrm{Ph} . \mathrm{D}$. in linguistics and the author of The Language of Judges (1993), is currently the Director of the Center for the Study of Law, Language and Cognition at Brooklyn Law School. See also SiDNEY I. LANDAU, DICTIONARIES: THE ART \& CRAFT OF LEXICOGRAPHY 6 (2d ed. 2001). "Dictionary is a powerful word. Authors and publishers have found that if they call a reference book a dictionary it tends to sell better than it would if called by another name because the word suggests authority, scholarship, and precision." Id.

3. Herbert C. Morton, THE StORy OF Webster's Third: Philip Gove's CONTROVERSIAL DictionARY AND ITS CRITICS 215 (1994) (facing page). The ad itself is reproduced infra in App. A.

4. Linda Greenhouse, The Year Rehnquist May Have Lost His Court, N.Y. TIMES, July 5, 2004, at Al ("The court decided 73 cases with full opinions during the term.").

5. See Hibbs v. Winn, 124 S. Ct. 2276, 2285 n.3 (2004) (citing Black's LAW DicTIONARY ( 7 th ed. 1999) in support of its construction of the term "assessment" in the Tax Injunction Act, 28 U.S.C. \$ 1341); Jones v. R.R. Donnelley \& Sons Co., 124 S. Ct. 1836, 1845 \& nn.15-16 (2004) (citing AMERICAN HERITAGE DICTIONARY (4th ed. 2000), BLACK's LAW DICTIONARY (4th ed. 1968), and OXFORD ENGLISH DICTIONARY (2d ed. 1989) in support of its construction of "arising under" in the federal catchall statute of limitations, 28 U.S.C. \$ 1658); Engine Mfrs. Ass'n v. S. Coast Air Quality Mgmt. Dist., 124 S. Ct. 1756, 1761 (2004) (citing WEBSTER'S SECOND NEW INTERNATIONAL DICTIONARY (1945) in support of its construction of the term "standard" in the Clean Air Act's pre-emption provision, 42 U.S.C. $\$ 7543(\mathrm{a})$ ); United States v. Galletti, 124 S. Ct. 1548, 1553 (2004) (citing BLACK's LAW DicTIONARY (7th ed. 1999) in support of its construction of the term "assessment" in $\$ 6502$ of the Internal Revenue Code, 26 U.S.C. $\$ 6502$ ).

6. See Crawford v. Washington, 124 S. Ct. 1354, 1364 (2004) (citing NoAH WEBSTER, AN AMERICAN DICTIONARY OF THE ENGLISH LANGUAGE (1828), in support of its construction of "witnesses" in the Sixth Amendment's Confrontation Clause, U.S. CoNST. amend. VI).

7. See Olympic Airways v. Husain, 124 S. Ct. 1221, 1226 \& n.6 (2004) (citing 
Term unusual on this score. Over the past twenty years, the Supreme Court has increasingly relied on dictionaries to explain its constructions of legal text. ${ }^{8}$ The federal judiciary, as a whole, has also cited both general purpose and law dictionaries more frequently in recent years. ${ }^{9}$

It should come as little surprise, then, that the U.S. Court of Appeals for the Federal Circuit ("Federal Circuit"), which hears all

American Heritage Dictionary (4th ed. 2000), Black's LaW Dictionary (6th ed. 1990), and WEBSTER'S NEW WORLD COLLEGE DICTIONARY (4th ed. 1999) in support of its construction of "accident" in the Warsaw Convention on injuries sustained during international air travel); Virginia v. Maryland, 124 S. Ct. 598, 603 \& n.2 (2003) (using BLACK'S LAW DICTIONARY (7th ed. 1999) to define "low-water mark" in applying an 1877 arbitrators' decision to a present-day riparian rights dispute between Virginia and Maryland).

8. The first two empirical studies of the phenomenon are Solan, supra note 2, at 51 (reporting data on Supreme Court citations to dictionaries from 1986 to 1991), and Note, Looking It Up: Dictionaries in Statutory Interpretation, 107 HARV. L. REV. 1437, 1438-40 (1994) (reporting data on Supreme Court citations to dictionaries from 1958 to 1992). The most comprehensive study of the Supreme Court's reliance on dictionaries, which covers the entire body of the Court's opinions through the 199798 term, is the magisterial Samuel A. Thumma \& Jeffrey L. Kirchmeier, The Lexicon Has Become a Fortress: The United States Supreme Court's Use of Dictionaries, 47 BuFF. L. REV. 227 (1999) [hereinafter Lexicon Fortress]. In this study, Thumma \& Kirchmeier observed that, "at the Court's present rate, the decade of the 1990 s will give rise to nearly half of all the opinions in the Court's two-century history where a Justice has relied on a dictionary." Id. at 260 (emphasis in original). In an update to their study, they report that their "predictions [in 1999] were correct: the 1990s alone accounted for nearly half of all the opinions in Supreme Court history in which the Court relied on a dictionary." Samuel A. Thumma \& Jeffrey Kirchmeier, The Lexicon Remains a Fortress: An Update, 5 GREEN BAG 2D 51, 52 (2001) (emphasis in original).

9. For example, using the search term (dictionary /6 ("webster's" or "american heritage" or "random house" or college or collegiate or concise or unabridged or oxford)) in Westlaw's allfeds database, one observes the following total number of "hits" annually over the last decade (reflecting a 37.2\% increase from 1994 to 2003):

\begin{tabular}{|c|c||c|c|}
\hline YEAR & NUMBER OF "HITS" & YEAR & NUMBER OF "HITS" \\
\hline 1994 & 537 & 1999 & 638 \\
\hline 1995 & 519 & 2000 & 610 \\
\hline 1996 & 565 & 2001 & 662 \\
\hline 1997 & 636 & 2002 & 718 \\
\hline 1998 & 628 & 2003 & 737 \\
\hline
\end{tabular}

In addition, using the search term ("black's law dictionary" or "bouvier's law dictionary" or "ballentine's law dictionary") in Westlaw's allfeds database, one observes the following total number of "hits" annually over the last decade (reflecting a $32.2 \%$ increase from 1994 to 2003 ):

\begin{tabular}{|c|c||c|c|}
\hline YEAR & NUMBER OF “HITS" & YEAR & NUMBER OF “HITS" \\
\hline 1994 & 515 & 1999 & 603 \\
\hline 1995 & 559 & 2000 & 643 \\
\hline 1996 & 517 & 2001 & 694 \\
\hline 1997 & 602 & 2002 & 691 \\
\hline 1998 & 549 & 2003 & 681 \\
\hline
\end{tabular}


appeals arising under the U.S. patent laws, ${ }^{10}$ has also turned increasingly to dictionaries when explaining its constructions of disputed terms in patent claims. Court reliance on dictionaries to construe disputed patent claim terms is, to be sure, nothing new. The regional circuit courts of appeal heard patent infringement appeals until the Federal Circuit's creation in 1982." The Court of Customs \& Patent Appeals heard appeals from Patent Office ${ }^{12}$ proceedings on patent applications until the Federal Circuit's creation in $1982 .{ }^{13}$ These courts, from time to time, expressly used dictionaries and similar reference sources to construe disputed claim terms. ${ }^{14}$ And the Federal Circuit itself, before a key turning point in

10. 28 U.S.C. $\$ 1295$ (a) (2002).

11. See Federal Courts Improvement Act of 1982, Pub. L. No. 97-164, 96 Stat. 25 (1982) (codified as amended in Title 28, U.S.C.) (establishing a United States Court of Appeals for the Federal Circuit). For a definitive study of the Federal Circuit's early years, see Rochelle Cooper Dreyfuss, The Federal Circuit: A Case Study in Specialized Courts, 64 N.Y.U. L. REV. 1 (1989).

12. The agency is formally called the "United States Patent and Trademark Office." 35 U.S.C. $\$ 1$ (a) (2002). This Article focuses on patent law questions and thus, as is common in the literature, refers to the agency simply as the "Patent Office." See, e.g., Jay P. Kesan, Carrots and Sticks to Create a Better Patent System, 17 BERKELEY TECH. L.J. 763, $765 \&$ n.l (2002) (using the term "Patent Office" instead of other acronyms to refer to patent activities of the United States Patent and Trademark Office); Robert P. Merges, One Hundred Years of Solicitude: Intellectual Property Law, 19002000, 88 CAL. L. REv. 2187, 2216-17 (2000) (describing the rise of Patent Office operations in the twentieth century).

13. See Dreyfuss, supra note 11 , at $3-5 \& \mathrm{n} .9$ (commentating on the creation of the Federal Circuit to allow for specialization and to reduce incoherence and differentiation between the circuits).

14. We found twelve such regional circuit cases spanning the period from 1900 to 1982: Saunders v. Air-Flo Co., 646 F.2d 1201, 1206, 1209, 210 U.S.P.Q. (BNA) 337, 341, 344, (7th Cir. 1981); Dickstein v. Seventy Corp., 522 F.2d 1294, 1297, 187 U.S.P.Q. (BNA) 138, 141 (6th Cir. 1975): Gen. Tire \& Rubber Co. v. Firestone Tire \& Rubber Co., 489 F.2d 1105, 1110 , 180 U.S.P.Q. (BNA) 98, 101 (6th Cir. 1973); Agrashell, Inc. v. Hammons Prods. Co., 413 F.2d 89, 92, 162 U.S.P.Q. (BNA) 449. 451 (8th Cir. 1969); Schmidinger v. Welsh, 383 F.2d 455, 463, 155 U.S.P.Q. (BNA) 289. 296 (3d Cir. 1967); Gomez v. Granat Bros., 177 F.2d 266, 268, 83 U.S.P.Q. (BNA) 197, 198 (9th Cir. 1949); Universal Oil Prods. v. Globe Oil \& Ref. Co., 137 F.2d 3, 6, 58 U.S.P.Q. (BNA) 504. 508 (7th Cir. 1943); Cabot v. J.M. Huber Corp., 127 F.2d 805, 807, 53 U.S.P.Q. (BNA) 442, 443 (5th Cir. 1942); Dernell Potato Prods. v. Snelling, 38 F.2d 788, 789, 4 U.S.P.Q. (BNA) 193, 194 (2d Cir. 1930); I.T.S. Rubber Co. v. Panther Rubber Mfg. Co., 260 F. 934, 938, 171 C.C.A. 576 (1st Cir. 1919); Frey v. Marvel Auto Supply Co., 236 F. 916, 920, 150 C.C.A. 178 (6th Cir. 1916); Am. Can Co. v. Hickmott Asparagus Canning Co., 142 F. 141, 145, 73 C.C.A. 359 (9th Cir. 1905).

We found eleven such cases from the Court of Customs \& Patent Appeals before 1982. See In re Gaubert, 524 F.2d 1222, 1226, 187 U.S.P.Q. (BNA) 664, 667 (C.C.P.A. 1975); In re Skoll, 523 F.2d 1392, 1395-96, 187 U.S.P.Q. (BNA) 481, 483 (C.C.P.A. 1975); In re Altenpohl, 500 F.2d 1151, 1157 \& n.7, 183 U.S.P.Q. (BNA) 38, 45 (C.C.P.A. 1974); In re McCue, 475 F.2d 1200, 1203, 177 U.S.P.Q. (BNA) 393, 395 (C.C.P.A. 1973); In re Wakefield, 422 F.2d 897, 902-03, 164 U.S.P.Q. (BNA) 636, 640 (C.C.P.A. 1970); In $r e$ Markert, 396 F.2d 477, 480, 158 U.S.P.Q. (BNA) 39, 41-42 (C.C.P.A. 1968); Liebscher v. Boothroyd, 258 F.2d 948, 951 \& n.2, 119 U.S.P.Q. (BNA) 133, 136 \& n.2 (C.C.P.A. 1958); In re Gabrielsen, 213 F.2d 545, 546, 102 
1995, expressly relied on dictionaries in explaining some of its claim construction rulings. ${ }^{15}$ As the data presented in this study show, however, the last nine years have seen more than a ten-fold increase in the number of times per year that the Federal Circuit, in its majority opinions, expressly relies on publicly available reference sources such as dictionaries, encyclopedias, and learned treatises ${ }^{16}$ compressed, for the remainder of this Article, to the more handy tag "dictionaries." The Federal Circuit, recognizing some of the questions raised by its increasing reliance on dictionaries, granted en banc review in a claim construction case in late July $2004 .{ }^{17}$ The court requested briefing on, among other things, the question whether "the public notice function of patent claims [is] better served by refer[r]ing primarily to technical and general purpose dictionaries and similar sources to interpret a claim term," or rather "by looking primarily to the patentee's use of the term in the specification" of the patent.

The Federal Circuit's turn to dictionaries is a key part of the court's ongoing effort to set out a predictable method for establishing the scope of a patent owner's right to exclude others from making, using, selling, or importing the invention established in the patent-the right that is the heart of every patent. ${ }^{19}$ This effort began in 1995 with

U.S.P.Q. (BNA) 120, 121 (C.C.P.A. 1954); In re Tamarin, 187 F.2d 160, 162, 88 U.S.P.Q. (BNA) 490, 492 (C.C.P.A. 1951); In re Ripper, 171 F.2d 297, 299, 80 U.S.P.Q. (BNA) 96, 98 (C.C.P.A. 1948); In re Curley, 158 F.2d 300, 304, 72 U.S.P.Q. (BNA) 116, 118-19 (C.C.P.A. 1946). In addition, we found two such cases in appeals from Patent Office proceedings that were taken to what is now the U.S. Court of Appeals for the D.C. Circuit. See Chapman v. Beede, 296 F. 956, 959-60 (D.C. Cir. 1924); Swain v. Booth, 295 F. 236, 237-38 (D.C. Cir. 1924).

To put in context the total number of such pre-Federal Circuit cases that we have found-twenty-five, or about one every three and one quarter years-consider that the Federal Circuit has issued twenty-three or more such opinions every year since 2000. See infra Tbl. 4.

15. See, e.g., Nike Inc. v. Wolverine World Wide, Inc., 43 F.3d 644, 647, 33 U.S.P.Q.2d (BNA) 1038, 1040 (Fed. Cir. 1994); Conopco, Inc. v. May Dep't. Stores Co., 46 F.3d 1556, 1561 \& n.2, 32 U.S.P.Q.2d (BNA) 1225, 1227 \& n.2 (Fed. Cir. 1994); Lantech, Inc. v. Keip Mach. Co., 32 F.3d 542, 547 \& n.5, 31 U.S.P.Q.2d (BNA) 1666,1670 \& n.5 (Fed. Cir. 1994); Hoganas AB v. Dresser Indus., 9 F.3d 948, 951 \& n.8, 28 U.S.P.Q.2d (BNA) 1936, 1938 \& n.8 (Fed. Cir. 1993); In re Wright, 999 F.2d 1557, 1562 \& n.6, 27 U.S.P.Q.2d (BNA) 1510, 1513 \& n.6 (Fed. Cir. 1993); Miles Labs., Inc. v. Shandon Inc., 997 F.2d 870, 876, 27 U.S.P.Q.2d (BNA) 1123, 1127 (Fed. Cir. 1993); Charles Greiner \& Co. v. Mari-Med Mfg., 962 F.2d 1031, 1035, 22 U.S.P.Q.2d (BNA) 1526, 1528 (Fed. Cir. 1992); Fromson v. Advance Offset Plate, Inc., 720 F.2d 1565, 1571, 219 U.S.P.Q. (BNA) 1137, 1141 (Fed. Cir. 1983).

16. See infra Tbl. 4.

17. Phillips v. AWH Corp., 376 F.3d 1382, 71 U.S.P.Q.2d (BNA) 1765 (Fed. Cir. 2004) (en banc order).

18. Id. at 1383, 71 U.S.P.Q.2d (BNA) at 1766. The court posed a total of seven questions, many of them compound, for additional briefing. $I d ., 71$ U.S.P.Q.2d (BNA) at 1766 .

19. See 35 U.S.C. $\$ 271$ (a) (2002) (providing that one who "without authority 
the court's decision in Markman v. Westview Instruments, ${ }^{20}$ where the court, en banc, held that it is for judges-not juries-to construe disputed terms in patents and thereby define patent rights. ${ }^{21}$ Because claim construction disputes frame nearly every issue in a patent infringement dispute, from the question whether the accused infringer has practiced the claimed invention to whether the patent was validly issued to begin with, ${ }^{22}$ most post-Markman Federal Circuit opinions in patent cases contribute to the court's claim construction jurisprudence. Systematic empirical study of the substance of this jurisprudence-of the public explanations that the Federal Circuit provides for the claim construction decisions it makes-is necessary to understand fully the scope, and thus the value, that patents generally possess. There is, however, almost no such systematic empirical study of the Federal Circuit's substantive claim construction case law. ${ }^{23}$

This Article helps to close that gap, presenting the first systematic empirical study of the Federal Circuit's use of dictionaries to help construe the scope of disputed patent rights. Specifically, we present both (a) top-level counts of yearly total dictionary citations in Federal

makes, uses, offers to sell, or sells any patented invention, within the United States or imports into the United States any patented invention during the term of the patent therefore, infringes the patent"); 35 U.S.C. \$ 281 ("A patentee shall have remedy by civil action for infringement of his patent."). As Chief Justice Taney long ago observed, "The franchise which the patent grants, consists altogether in the right to exclude every one from making, using, or vending the thing patented, without the permission of the patentee. This is all that he obtains by the patent." Bloomer $\mathrm{v}$. McQuewan, 55 U.S. 539, 549 (1852).

20. 52 F.3d 967, 34 U.S.P.Q.2d (BNA) 1321 (Fed. Cir. I995) (en banc).

21. Id. at 979, 34 U.S.P.Q.2d (BNA) at 1329. A year later, the Supreme Court affirmed the Federal Circuit's allocation of claim construction authority to judges. Markman v. Westview Instruments, 517 U.S. 370, 372 (1996) ("We hold that the construction of a patent, including terms of art within its claim, is exclusively within the province of the court.").

22. See Rockwell Int'l Corp. v. United States, 147 F.3d 1358, 1362, 47 U.S.P.Q.2d (BNA) 1027, 1029 (Fed. Cir. 1998) ("The first step in any invalidity or infringement analysis is claim construction."). As Professor Wagner and Mr. Petherbridge note in their recent empirical study of Federal Circuit claim construction methodology, "Though the precise magnitude of its role is a matter of considerable debate, it is clear that claim construction plays a major-and perhaps the major-role in patent infringement litigation." R. Polk Wagner \& Lee Petherbridge, Is the Federal Circuit Succeeding? An Empirical Assessment of Judicial Performance, 152 U. PA. L. Rev. 1105, 1119 (2004) (footnote omitted); see also JANICE M. MUELlER, AN INTRODUCTION TO PATENT LAW 8 (2003) ("The interpretation and scope of the claims will be the focal point of any litigation involving the patent. The language of the claims is scrutinized intensely in analyzing both the validity of the patent and whether it has been infringed.").

23. Wagner \& Petherbridge, supra note 22, at 1110-11 \& n.16, 1127 \& n.83 (discussing the outcome-based methodology used in nearly all empirical studies of the Federal Circuit). Indeed, the Wagner \& Petherbridge study is the first systematic empirical study of the substance of the Federal Circuit's claim construction methodology. See id. at 1110-11. 
Circuit and district court patent cases for the last decade, and (b) detailed data from a review of all Federal Circuit opinions, precedential and nonprecedential, from April 5, 1995 (the date of the court's Markman decision) to June 30, 2004, in which the majority opinion for the court expressly relied on one or more dictionaries to help construe a word in a disputed patent claim. The dataset from this detailed review, a copy of which we provide as Appendix $\mathrm{C}$ to this Article, identifies all the cases reporting such dictionary use, the specific sources the court used, the words it defined, and the judges who authored each of the opinions in the study.

This Article also takes the next step that the data suggest, presenting the normative case for integrating the choice of preferred reference sources into the patent application and examination process at the Patent Office. Starting from the Federal Circuit's stated reasons for relying on dictionaries, which focus on the need for neutral reference materials that can ground predictable claim scope analysis, we show that the court's desiderata cannot likely be achieved so long as courts remain effectively free, as they are now, to choose whatever dictionaries they favor after litigation has already begun. ${ }^{24}$ We further show that the Patent Office can and should use its power to regulate patent examination proceedings ${ }^{25}$ to mandate that all patent applicants identify the general purpose and technical dictionaries to which parties should refer when construing the words in their patent claims, and that the dictionaries so identified be listed on the face of any resulting issued patent. Indeed, only the Patent Office, a key player in the multi-institutional framework that is our

24. Our normative goal is not to show that the Federal Circuit's reliance on dictionaries to establish ordinary meaning is sound, but is rather to show how, given the commitment to rely on dictionaries for this purpose, one can make the use of dictionaries more neutral and predictable for all parties. The existing literature on the deeper normative question-is it sound to use dictionaries to help establish a word's ordinary meaning?-is substantial. The interested reader should consult, in addition to the works cited already, supra note 8, the following sources: Ellen P. Aprill, The Law of the Word: Dictionary Shopping in the Supreme Court, 30 ARIz. ST. L.J. 275 (1998); Clark D. Cunningham et al., Plain Meaning and Hard Cases, 103 Yale L.J. 1561 (1994); Craig Hoffman, Parse the Sentence First: Curbing the Urge to Resort to the Dictionary When Interpreting Legal Texts, 6 N.Y.U. J. Legis. \& PUB. POL'Y 401 (20022003); Gary L. McDowell, The Politics of Meaning: Law Dictionaries and the Liberal Tradition of Interpretation, 44 AM. J. LEGAL HIST. 257 (2000); Aaron J. Rynd, Dictionaries and the Interpretation of Words: A Summary of Difficulties, 29 ALBERTA L. REV. 712 (1991); and Lawrence M. Solan, Leaming Our Limits: The Decline of Textualism in Statutory Cases, 1997 WIS. L. REv. 235.

25. 35 U.S.C. $\$ 2$ (b) (2) (A) (2002) (giving the Patent Office the power to "establish regulations, not inconsistent with law, which ... shall govern the conduct of proceedings in the Office"). 
patent system, ${ }^{26}$ is well-placed to bring about the predictable and neutral deployment of dictionaries that the Federal Circuit envisions.

Part I begins with the top-level data about the rate at which the Federal Circuit and the district courts cite dictionaries when construing patent claim terms. Then, as a bridge to the data resulting from detailed case review, Part I examines the Federal Circuit's evolving rationale for using dictionaries in the claim construction process-a rationale reflected in a small number of milestone decisions in the post-Markman era. In these cases, the Federal Circuit moves from a largely expertise-based rationale for dictionaries (according to which one might predict more frequent reliance on technical or specialized sources than on general purpose English language dictionaries) to a neutrality-based rationale (according to which one might predict no greater reliance on specialized than on general purpose sources). Finally, Part I provides a detailed assessment of every occasion, from its April 1995 decision in Markman to the end of June 2004, that the Federal Circuit has reported relying on a dictionary or similar source to construe the meaning of a word in a patent claim. The data show, among other things, that the neutrality-based rationale more accurately reflects the court's actual dictionary citation behavior.

Part II explores existing constraints on a court's choice of dictionary for use in claim construction. At present, the constraints are minimal. Indeed, in the milestone Telegenix case, the Federal Circuit emphasizes the absence of such constraints as an apparent boon for the courts. ${ }^{27}$ Our discussion reveals, however, that the courts' unfettered discretion to choose whatever dictionaries they may favor during the litigation process threatens to undermine the Federal Circuit's professed goals of greater neutrality and predictability in claim construction. Part II closes with a demonstration that this unfettered discretion presents a real jurisprudential and institutional problem. It analyzes three recent cases where dictionary selection had a palpable effect on the claim construction outcome.

26. See generally Arti K. Rai, Engaging Facts and Policy: A Multi-Institutional Approach to Patent System Reform, 103 CoLUM. L. REV. 1035, 1036-40 (2003) (discussing the need for patent reforms that consider all patent system actors, including the Federal Circuit, the Patent Office, the federal trial courts, and the Supreme Court).

27. See Tex. Digital Sys., Inc. v. Telegenix, Inc., 308 F.3d 1193, 1202-04, 64 U.S.P.Q.2d (BNA) 1812, 1818-20 (Fed. Cir. 2002) ("As resources and references to inform and aid courts and judges in the understanding of technology and terminology, it is entirely appropriate for both trial and appellate judges to consult these materials at any stage of a litigation, regardless of whether they have been offered by a party in evidence or not.") (emphasis added). 
Part III proposes a new approach to choosing dictionaries for claim construction-an approach that preserves the neutrality of these sources by eliminating the apparent arbitrariness that now attends their selection by the courts. The key to this approach is to place dictionary selection squarely in the patent applicant's hands and push it back in time to the patent's examination phase at the Patent Office, i.e., before a concrete infringement dispute skews one's preferred construction. Indeed, it is precisely when a would-be patentee files for patent protection that the applicant can most readily match the background reference sources for claim word meaning-whether ordinary or specialized-to the intended scope of the claim. Thereafter, third parties and the courts would know which reference sources to consult when construing words in the resulting patent, whether for licensing, design-around, or litigation purposes. The enhanced predictability and reduced cost of assessing the scope of the resulting patent, which would benefit every member of the interested public for the entire multi-year term of the patent, should more than offset the increased cost to the applicant of determining which dictionaries he prefers.

\section{THE RISE AND Rise OF Dictionaries AT THE FEDERAL CiRCUIT}

Before discussing our empirical results, it is useful to review briefly the basic way that patent claims define patent rights, as well as some of the fixed stars that guide patent claim construction.

Every utility patent-the most common kind of patent, ${ }^{28}$ and the subject of this study-ends with one or more separately numbered paragraphs, known as "claims."

28. U.S. law provides for three separate types of patents: utility patents, design patents, and plant patents. See MUELLER, supra note 22, at 169 \& n.1,194-96. Utility patents cover useful, new, and nonobvious products and processes. 35 U.S.C. $\$ \$ 101$ 103. This is the sort of patent most people think of as, simply, a patent. Design patents cover new, original, and ornamental designs for "article[s] of manufacture." 35 U.S.C. $\$ \$ 171-173$. Plant patents cover distinct and new varieties of plants that are asexually reproduced. 35 U.S.C. $\$ \S 161-164$. The Patent Office grants many more utility patents than design or plant patents. For example, during the eight years from 1994 to 2001 inclusive, the Patent Office granted 1,049,260 utility patents (or about 131,158 per year); 109,414 design patents (or about 13,677 per year); and 3,755 plant patents (or about 470 per year). See U.S. PATENT AND TRADEMARK OfFICE, U.S. PATENT STATISTICS, CALENDAR YEARS 1963-2001 (2004) (reporting annual grant totals), available at http://www.uspto.gov/web/offices/ac/ido/oeip/taf/us_stat.pdf.

29. As Professor Mueller puts it, "A patent claim is a precision-drafted, singlesentence definition of the patent owner's right to exclude others." MUELLER, supra note 22, at 37. For example, U.S. Patent No. 6,263,732 (issued July 24, 2001), entitled "Measuring Cup," has a single claim. One of us used this patent as the basis for a semester-long writing project in his basic Patent Law class. The sole claim of the patent provides as follows:

1. A measuring device, comprising: 
the patentee to provide these numbered claim paragraphs, the prescribed function of which is to "particularly point[] out and distinctly claim[] the subject matter which the applicant regards as his invention." ${ }^{30}$ Each of the claims gives the patentee a separate right to exclude others, ${ }^{31}$ the scope of which is determined by the words in that claim. As the Federal Circuit put it in a recent case, "the claims define the scope of the right to exclude; the claim construction inquiry, therefore, begins and ends in all cases with the actual words of the claims."

Patents are, of course, legal instruments. The rights they create, however, involve varied, and sometimes quite complex, technologies. Of necessity, then, patent claims often use a range of specialized technical terms. ${ }^{33}$ When a generalist federal judge ${ }^{34}$ confronts a claim

a bottom wall and a generally vertical and encircling side wall having a lower edge and an upper edge, said sidewall defining an upwardly opening cup with an upper end;

a spout attached integrally to said side wall; and

a pair of continuously sloping ramps formed integrally with and radially inward in relief from said sidewall, said ramps extending from about said bottom wall generally opposite said spout toward said open upper end generally adjacent said spout, wherein said ramp is coextensive with said spout, said ramp having an upwardly directed surface and indicia located on said upwardly directed surface being at least one of standard and metric units of measurement providing a readily observable indication of the volume of the contents contained within said cup.

Id. at col. 4,1.59-col. $6,1.3$. As Figures 4 through 6 in the ' 732 patent suggest, and the matching patent number molded into its plastic bottom confirms, the OXObrand "Angled Measuring Cup" (a picture of which you can call up in the Kitchen \& Housewares section of http://www.amazon.com) embodies the invention in this claim.

30. 35 U.S.C. $\$ 112$. The Patent Act has contained this claiming requirement since 1870. See Act of July 8, 1870, ch. 230, § 26, 16 Stat. 198, 201 (1870); see also William R. Woodward, Definiteness and Particularity in Patent Claims, $46 \mathrm{MICH}$. L. REv. $755,757-60$ (1948) (tracing the history of the modern patent claim in U.S. patent law).

31. See 35 U.S.C. $\$ 282$ (providing that "[e]ach claim of a patent ... shall be presumed valid independently of the validity of other claims"); Leeds \& Catlin Co. v. Victor Talking Mach. Co., 213 U.S. 301, 319 (1909) (discussing the legal separateness and viability of individual patent claims); MUELLER, supra note 22, at 37-39.

32. Renishaw PLC v. Marposs Societa' Par Azioni, 158 F.3d 1243, 1248, 48 U.S.P.Q.2d (BNA) 1117, 1120 (Fed. Cir. 1998); see also AbTox, Inc. v. Exitron Corp., 122 F.3d 1019, 1023, 43 U.S.P.Q.2d (BNA) 1545, 1548 (Fed. Cir. 1997) ("the language of the claim frames and ultimately resolves all issues of claim interpretation," and "throughout the interpretation process, the focus remains on the meaning of claim language"). In this respect, the Federal Circuit is simply following a path cleared more than a century ago by the Supreme Court. See also Yale Lock Mfg. v. Greenleaf, 117 U.S. 554, 559 (1886) ("The scope of letters patent must be limited to the invention covered by the claim, and while the claim may be illustrated it cannot be enlarged by language used in other parts of the specification.”); Keystone Bridge Co. v. Phoenix Iron Co., 95 U.S. 274, 278 (1877) "When the terms of a claim in a patent are clear and distinct (as they always should be), the patentee, in a suit brought upon the patent, is bound by it.").

33. For example, contrast the largely familiar terminology from the " 732 patent, 
construction dispute, she must both preserve the specialized meaning of claim terms and ensure that her chosen construction preserves the patent's internal coherence as a legal instrument. The Supreme Court, in fact, emphasized the need to ensure a patent's integrity as a legal instrument when it affirmed the Federal Circuit's allocation of claim construction authority to the judiciary. ${ }^{33}$

How, then, do courts structure the claim construction inquiry to best ensure both technological fidelity and documentary coherence? Two overarching principles frame the claim construction process. First, a court must construe claim terms as would a person of ordinary skill in the field of art to which the patent pertains. As the Federal Circuit recently summarized it,

It is the person of ordinary skill in the field of the invention through whose eyes the claims are construed. Such person is deemed to read the words used in the patent documents with an understanding of their meaning in the field, and to have knowledge of any special meaning and usage in the field. ${ }^{36}$

supra note 29 , with the more specialized terminology from claim 1 of U.S. Patent No. 4,736,866 (issued Apr. 12, 1988), entitled "Transgenic Non-Human Mammals":

1. A transgenic non-human mammal all of whose germ cells and somatic cells contain a recombinant activated oncogene sequence introduced into said mammal, or an ancestor of said mammal, at an embryonic stage.

Id. at col. 9, 1. 35-col. 10, 1. 2. This patent is better known as the (in)famous Harvard oncomouse patent. See Janice M. Mueller, No "Dilettante Affair": Rethinking the Experimental Use Exception to Patent Infringement for Biomedical Research Tools, 76 WASH. L. REV. 1, 13 \& nn.58-59 (2001) (discussing the importance of the oncomouse patent in the context of patent-protected biomedical research tools); Dashka Slater, huMouse ${ }^{\text {TM }}$, LEGAL AFFS., Nov.-Dec. 2002, at 20, 25 (discussing the oncomouse patent in the context of debates over the patentability of living, genetically modified organisms); The Harvard Mouse: A Short History, CoRP. LEGAL TIMES, Mar. 2003, at 30 (recounting Harvard's efforts to patent the oncomouse).

34. See John Shepard Wiley, Jr., Taming Patent: Six Steps for Surviving Scary Patent Cases, 50 UCLA L. REv. 1413, 1417 (2003) (

There are no science prerequisites in Article III. Nothing in the process of selecting federal judges screens for technologists. We therefore may fairly picture the average district judge as a smart, accomplished, and legally sophisticated person who is technologically ignorant: an able and successful lawyer before appointment, but a person who might have been a history or English major and who may never have taken a course in calculus or in any basic science at all.

).

35. See Markman v. Westview Instruments, Inc., 517 U.S. 370, 389-90 (1996) ("In the main ... any credibility determinations [regarding expert witnesses] will be subsumed within the necessarily sophisticated analysis of the whole [patent] document, required by the standard construction rule that a term can be defined only in a way that comports with the instrument as a whole. . . The decisionmaker [now] vested with the task of construing the patent [i.e., the judge(s)] is in the better position to ascertain whether an expert's proposed definition fully comports with the specification and claims and so will preserve the patent's internal coherence.") (citations omitted).

36. Multiform Desiccants, Inc. v. Medzam, Ltd., 133 F.3d 1473, 1477, 45 
Taking on this perspective requires a judge to dip into the substance of the pertinent art; litigation parties must thus find ways to deliver this substance effectively.

Second, a court must start with a baseline, a default meaning for the words in a patent claim; the party who contends the default meaning is inappropriate must carry the burden of proving that contention. The default rule is, according to the Federal Circuit, a word's "ordinary meaning": "As a starting point, we give claim terms their ordinary and accustomed meaning as understood by one of ordinary skill in the art." ${ }^{38}$ This "ordinary meaning" default for patent claim terms is a longstanding one: it originates in regional circuit law, ${ }^{39}$ and the Federal Circuit has long observed it. ${ }^{40}$

U.S.P.Q.2d (BNA) 1429, 1432 (Fed. Cir. 1998); see also K-2 Corp. v. Salomon S.A., 191 F.3d 1356, 1362, 1365, 52 U.S.P.Q.2d (BNA) 1001, 1006 (Fed. Cir. 1999) (“[C] laim construction is firmly anchored in reality by the understanding of those of ordinary skill in the art."); Cole v. Kimberly-Clark Corp., 102 F.3d 524, 531, 41 U.S.P.Q.2d (BNA) 1001, 1006 (Fed. Cir. 1996) ("The district court correctly recognized that words in a patent claim are construed as they would be understood by a reader skilled in the relevant art unless it appears that the inventor used the words differently.").

There are, as experienced patent practitioners know, some words that have become terms of patent law art. The court construes these not as a technically trained person would but rather as a trained patent lawyer would. Thus, for example, the court construes the transition word "comprising" to mean "including, but not limited to" and construes the transition phrase "consisting of" to mean "including only." See, e.g., Medichem, S.A. v. Rolabo, S.L., 353 F.3d 928, 933, 69 U.S.P.Q.2d (BNA) 1283, 1287 (Fed. Cir. 2003); PPG Indus. v. Guardian Indus., 156 F.3d 1351, 1354-55, 48 U.S.P.Q.2d (BNA) 1351, 1353-54 (Fed. Cir. 1998).

37. See Wiley, Jr., supra note 34, at 1420 ("If judges do not begin with specialized knowledge but must make difficult scientific and technical decisions, what is to be done? Plainly they must gain a scientific and technical education if they are to perform their work with competence.").

38. Bell Atl. Network Servs., Inc. v. Covad Communications Group, Inc., 262 F.3d 1258, 1267, 59 U.S.P.Q.2d (BNA) 1865, 1870 (Fed. Cir. 2001); see also ResQNet.com, Inc. v. Lansa, Inc., 346 F.3d 1374, 1378, 68 U.S.P.Q.2d (BNA) 1619, 1622 (Fed. Cir. 2003). "A fundamental principle for discerning the usage of claim language is the ordinary and accustomed meaning of the words amongst artisans of ordinary skill in the relevant art at the time of invention." ResQNet.com, 346 F.3d at 1378, 68 U.S.P.Q.2d (BNA) at 1622 .

39. See Universal Oil Prods. Co. v. Globe Oil \& Ref. Co., 137 F.2d 3, 6, 58 U.S.P.Q. (BNA) 504, 508 (7th Cir. 1943) ("[W]ords will be given their ordinary and accustomed meaning unless it appears that the inventor used them differently.").

40. See Renishaw PLC v. Marposs Societa' Per Azioni, 158 F.3d 1243, 1249-50, 48 U.S.P.Q.2d (BNA) 1117, 1121-22 (Fed. Cir. 1998); Kegel Co. v. AMF Bowling, Inc., 127 F.3d 1420, 1427, 44 U.S.P.Q.2d (BNA) 1123, 1127 (Fed. Cir. 1997); Bell Communications Research, Inc. v. Vitalink Communications Corp., 55 F.3d 615, 620, 34 U.S.P.Q.2d (BNA) 1816, 1819-20 (Fed. Cir. 1995); In re Paulsen, 30 F.3d 1475, 1480, 31 U.S.P.Q.2d (BNA) 1671, 1674 (Fed. Cir. 1994); Nike Inc. v. Wolverine World Wide, Inc., 43 F.3d 644, 646, 33 U.S.P.Q.2d (BNA) 1038, 1039 (Fed. Cir. 1994); Carroll Touch, Inc. v. Electro Mech. Sys., 15 F.3d 1573, 1577, 27 U.S.P.Q.2d (BNA) 1836, 1840 (Fed. Cir. 1993); Intellicall, Inc. v. Phonometrics, Inc., 952 F.2d 1384, 1387, 21 U.S.P.Q.2d (BNA) 1383, 1386 (Fed. Cir. 1992); Envirotech Corp. v. Al George, Inc., 730 F.2d 753, 759, 221 U.S.P.Q. (BNA) 473, 477 (Fed. Cir. 1984).

40. Johnson Worldwide Assocs. v. Zebco Corp., 175 F.3d 985, 989, 50 U.S.P.Q.2d 
In recent years, however, the Federal Circuit has strengthened this principle by underscoring the way that it structures the process of proving the meaning of a disputed claim term. Specifically, beginning in 1999 with Johnson Worldwide Associates v. Zebco Corp., ${ }^{41}$ the court has linked the "ordinary meaning" default to that familiar proof-structuring device, the presumption: ${ }^{42}$

The general rule is, of course, that terms in the claim are to be given their ordinary and accustomed meaning. General descriptive terms will ordinarily be given their full meaning; modifiers will not be added to broad terms standing alone. In short, a court must presume that the terms in the claim mean what they say, and, unless otherwise compelled, give full effect to the ordinary and accustomed meaning of claim terms.

In order to overcome this heavy presumption in favor of the ordinary meaning of claim language, it is clear that "a party wishing to use statements in the written description to confine or otherwise affect a patent's scope must, at the very least, point to a term or terms in the claim with which to draw in those statements." ${ }^{43}$

The Johnson Worldwide shift to a "heavy presumption" has stuck. Indeed, the Federal Circuit has invoked this "heavy presumption" in at least twenty-two of its precedential claim construction decisions in the past two and one-half years. ${ }^{44}$

(BNA) 1607, 1610 (Fed. Cir. 1999).

41. Id. at 989,50 U.S.P.Q.2d (BNA) at 1610.

42. See Ronald J. Allen, The Explanatory Value of Analyzing Codifications by Reference to Organizing Principles Other Than Those Employed in the Codification, 79 Nw. U. L. REV. 1080 , 1090 (1984-1985) ("Once the label is pierced, it becomes obvious that the word 'presumption' is the label applied to the various methods of structuring the processof-proof at trial, in particular (but not limited to) allocations of burdens of production and persuasion and judicial summary and comment on the evidence."). It may seem strange, in the context of a discussion about how one establishes a proposition of law (i.e., the meaning of a disputed claim term), to invoke constructs familiar from the process of proving facts. Standards of proof and presumptions, however, are just as useful-indeed, necessary-in adjudicating law disputes as they are in adjudicating fact disputes. See generally Gary Lawson, Proving the Law, 86 Nw. U. L. REv. 859 (1992) (discussing the need for an appropriate standard of proof in legal interpretive theory). See also James R. Barney, In Search of "Ordinary Meaning", $85 \mathrm{~J}$. PAT. \& TRADEMARK OFF. SOC'Y 101, 109 (2003) ("By imposing a 'heavy presumption' ... courts essentially impose a burden of proof on whichever party opposes th [e] ordinary and accustomed meaning.").

43. Johnson Worldwide, 175 F.3d at 989, 50 U.S.P.Q.2d (BNA) at 1610 (citations omitted) (quoting Renishaw, 158 F.3d at 1248, 48 U.S.P.Q.2d (BNA) at 1121).

44. See Goldenberg v. Cytogen, Inc., 373 F.3d 1158, 1164, 71 U.S.P.Q.2d (BNA) 1255, 1259 (Fed. Cir. 2004); Metabolite Labs., Inc. v. Lab. Corp. of Am. Holdings, 370 F.3d 1354, 1360, 71 U.S.P.Q.2d (BNA) 1081, 1085 (Fed. Cir. 2004); W.E. Hall Co. v. Atlanta Corrugating, LLC, 370 F.3d 1343, 1350, 71 U.S.P.Q.2d (BNA) 1135, 1140 (Fed. Cir. 2004); Housey Pharms., Inc. v. AstraZeneca UK Ltd., 366 F.3d 1348, 1352, 70 U.S.P.Q.2d (BNA) 1641, 1643 (Fed. Cir. 2004); Norian Corp. v. Stryker Corp., 363 F.3d 1321, 1334, 70 U.S.P.Q.2d (BNA) 1508, 1518 (Fed. Cir. 2004); Golight, Inc. v. WalMart Stores, Inc., 355 F.3d 1327, 1332, 69 U.S.P.Q.2d (BNA) 
The heavy presumption of ordinary meaning for patent claim terms puts a premium on identifying that ordinary meaning. How is a court to do so? One key way appears to be by looking up the disputed claim word in a dictionary: "Standard dictionary definitions indicate ordinary meaning." In fact, it is hardly surprising that, in the midst of a decade of Supreme Court statutory interpretation cases equating ordinary meaning with the content of general purpose English language and law dictionaries, ${ }^{46}$ the Federal Circuit would

1481, 1485 (Fed. Cir. 2004); ResQNet.com, Inc. v. Lansa, Inc., 346 F.3d 1374, 1378, 68 U.S.P.Q.2d (BNA) 1619, 1622 (Fed. Cir. 2003); Genzyme Corp. v. Transkaryotic Therapies, Inc., 346 F.3d 1094, 1098, 68 U.S.P.Q.2d (BNA) 1596, 1599 (Fed. Cir. 2003); E-Pass Techs., Inc. v. 3Com Corp., 343 F.3d 1364, 1368, 67 U.S.P.Q.2d (BNA) 1947, 1950 (Fed. Cir. 2003); Sunrace Roots Enter. Co. v. SRAM Corp., 336 F.3d 1298, 1302, 67 U.S.P.Q.2d (BNA) 1438, 1441 (Fed. Cir. 2003); Omega Eng'g, Inc. v. Raytech Corp., 334 F.3d 1314, 1323, 67 U.S.P.Q.2d (BNA) 1321, 1327 (Fed. Cir. 2003); Apex Inc. v. Raritan Computers, Inc., 325 F.3d 1364, 1371, 66 U.S.P.Q.2d (BNA) 1444, 1449 (Fed. Cir. 2003); Northrup Grumman Corp. v. Intel Corp., 325 F.3d 1346, 1355, 66 U.S.P.Q.2d (BNA) 1341, 1347 (Fed. Cir. 2003); Riverwood Int'l Corp. v. R.A. Jones \& Co., 324 F.3d 1346, 1357, 66 U.S.P.Q.2d (BNA) 1331, 1339 (Fed. Cir. 2003); Altiris, Inc. v. Symantec Corp., 318 F.3d 1363, 1369, 65 U.S.P.Q.2d (BNA) 1865,1869 (Fed. Cir. 2003); Prima Tek II, L.L.C. v. Polypap, S.A.R.L., 318 F.3d 1143, 1148, 65 U.S.P.Q.2d (BNA) 1818, 1821 (Fed. Cir. 2003); Amgen Inc. v. Hoechst Marion Roussel, Inc., 314 F.3d 1313, 1327, 65 U.S.P.Q.2d (BNA) 1385, 1394 (Fed. Cir. 2003); Tex. Digital Sys., Inc. v. Telegenix, Inc., 308 F.3d 1193, 1202, 64 U.S.P.Q.2d (BNA) 1812, 1817-18 (Fed. Cir. 2002); Union Carbide Chems. \& Plastics Tech. Corp. v. Shell Oil Co., 308 F.3d 1167, 1177, 64 U.S.P.Q.2d (BNA) 1545, 1551 (Fed. Cir. 2002); Teleflex, Inc. v. Ficosa N. Am. Corp., 299 F.3d 1313, 1325, 63 U.S.P.Q.2d (BNA) 1374, 1380 (Fed. Cir. 2002); CCS Fitness, Inc. v. Brunswick Corp., 288 F.3d 1359, 1366, 62 U.S.P.Q.2d (BNA) 1658, 1662 (Fed. Cir. 2002); Leggett \& Platt, Inc. v. Hickory Springs Mfg., 285 F.3d 1353, 1357, 62 U.S.P.Q.2d (BNA) 1266, 1269 (Fed. Cir. 2002).

45. MSM Invs. Co. v. Carolwood Corp., 259 F.3d 1335, 1339 n.*, 59 U.S.P.Q.2d (BNA) 1856, 1859 \& n.* (Fed. Cir, 2001) (relying on Webster's II New Riverside University Dictionary for ordinary meaning of "feed"); see also Apex, 325 F.3d at 1371, 66 U.S.P.Q.2d (BNA) at 1449 (“[D]ictionary definitions may be consulted in establishing a claim term's ordinary meaning."); CCS Fitness, 288 F.3d at 1366, 62 U.S.P.Q.2d (BNA) at 1662 ("Sensibly enough, our precedents show that dictionary definitions may establish a claim term's ordinary meaning.").

46. The Supreme Court used one or more dictionaries to provide an "ordinary meaning" for a disputed statutory term at least thirteen times between 1991 and June 2004. See Engine Mfrs. Ass'n v. S. Coast Air Quality Mgmt. Dist., 124 S. Ct. 1756, 1761 (2004); Nat'l R.R. Passenger Corp. v. Morgan, 536 U.S. 101, 109 \& n.5 (2002); Williams v. Taylor, 529 U.S. 420, 431-32 (2000); United States v. LaBonte, 520 U.S. 751, 757-58 (1997); Ingalls Shipbuilding Inc. v. United States Dep't of Labor, 519 U.S. 248, 255-56 (1997); Walters v. Metro. Educ. Enters., Inc., 519 U.S. 202, 207-08 (1997); Bailey v. United States, 516 U.S. 137, 144-45 (1995); Asgrow Seed v. Winterboer, 513 U.S. 179, 187 (1995); United States v. Alvarez-Sanchez, 511 U.S. 350, 357-58 (1994); F.D.I.C. v. Meyer, 510 U.S. 471,476 (1994); Smith v. United States, 508 U.S. 223, 228-29 (1993); Pioneer Inv. Servs. Co. v. Brunswick Assocs. Ltd. P'ship, 507 U.S. 380, 388 (1993); Chapman v. United States, 500 U.S. 453, 461-62 (1991).

The Federal Circuit, for its part, has used the same ordinary meaning/dictionary methodology in many of its statutory interpretation decisions since 1985. See Bayer AG v. Housey Pharms., Inc., 340 F.3d 1367, 1371, 68 U.S.P.Q.2d (BNA) 1001, 1004 (Fed. Cir. 2003); Nippon Steel Corp. v. United States, 337 F.3d 1373, 1382 (Fed. Cir. 2003); Alloy Piping Prods., Inc. v. Kanzen Tetsu Sdn. Bhd., 334 F.3d 1284, 1289 (Fed. 
turn to dictionaries to establish the ordinary meanings of disputed claim terms. So comfortable is it with equating ordinary meaning to dictionary content that the Federal Circuit, in its milestone Telegenix case endorsing dictionaries as claim construction tools, slips in the space of two pages from a "heavy presumption" of "ordinary meaning" to "the presumption in favor of a dictionary definition." Telegenix also expressly supports the use of dictionaries to provide the ordinary meanings of claim terms by analogizing such use to relianće on dictionaries for ordinary meanings in statutory construction cases. $^{49}$ Importantly, as Telegenix itself takes pains to emphasize, consulting a dictionary is simply the first step in a properly conducted claim construction analysis, and it can never be the last step. ${ }^{50}$

Cir. 2003); Info. Tech. \& Applications Corp. v. United States, 316 F.3d 1312, 1320 (Fed. Cir. 2003); Liesegang v. Sec'y of Veterans Affairs, 312 F.3d 1368, 1374-75 (Fed. Cir. 2002); Mudge v. United States, 308 F.3d 1220, 1227-28 (Fed. Cir. 2002); Am. Express Co. v. United States, 262 F.3d 1376, 1381 \& n.5 (Fed. Cir. 2001); AK Steel Corp. v. United States, 226 F.3d 1361, 1371 (Fed. Cir. 2000); Int'l Bus. Machs. Corp. v. United States, 201 F.3d 1367, 1372 (Fed. Cir. 2000); Aimcor v. United States, 141 F.3d 1098, 1109 (Fed. Cir. 1998); NSK Ltd. v. United States, 115 F.3d 965, 975 (Fed. Cir. 1997); Cook v. Brown, 68 F.3d 447, 451 (Fed. Cir. 1995); Jones v. Brown, 41 F.3d 634, 638 (Fed. Cir. 1994); Koyo Seiko Co., Ltd. v. United States, 36 F.3d 1565, 1571 \& n.9 (Fed. Cir. 1994); Sharp v. United States, 14 F.3d 583, 587-88 (Fed. Cir. 1993); Best Power Tech. Sales Corp. v. Austin, 984 F.2d 1172, 1177 (Fed. Cir. 1993); In re Canadian Pac. Ltd., 754 F.2d 992, 994, 224 U.S.P.Q. (BNA) 971, 973 (Fed. Cir. 1985).

47. Tex. Digital Sys., Inc. v. Telegenix, Inc., 308 F.3d 1193, 1202, 64 U.S.P.Q.2d (BNA) 1812,1818 (Fed. Cir. 2002).

48. Id. at 1204, 64 U.S.P.Q.2d (BNA) at 1819.

49. See id. at 1203, 64 U.S.P.Q.2d (BNA) at 1818 (providing examples of courts using dictionaries to "aid in the interpretation of statutes and regulations" in cases involving tariff terms and Internal Revenue Service regulations).

50. See id., 64 U.S.P.Q.2d at 1819 (stressing that "[b]ecause words often have multiple dictionary definitions, some having no relation to the claimed invention, the intrinsic record must always be consulted to identify which of the different possible dictionary meanings of the claim terms in issue is most consistent with the use of the words by the inventor"); id. at 1204, 64 U.S.P.Q.2d at 1819 (insisting that "the intrinsic record also must be examined in every case to determine whether the presumption of ordinary and customary meaning is rebutted"). In one post-Telegenix case, the Federal Circuit further emphasized this fundamental point:

While dictionaries and treatises are useful resources in determining the ordinary and customary meaning or meanings of disputed claim terms, the correct meaning of a word or phrase is informed only by considering the surrounding text. This is why consulting dictionary definitions is simply a first step in the claim construction analysis and is another reason why resort must always be made to the surrounding text of the claims in question, the other claims, the written description, and the prosecution history. Our precedent referencing the use of dictionaries should not be read to suggest that abstract dictionary definitions are alone determinative. In construing claim terms, the general meanings gleaned from reference sources, such as dictionaries, must always be compared against the use of the terms in context, and the intrinsic record must always be consulted to identify which of the different possible dictionary meanings is most consistent with the use of the words by the inventor.

Brookhill-Wilk 1, LLC v. Intuitive Surgical, Inc., 326 F.3d 1215, 1221-22, 66 U.S.P.Q.2d (BNA) 1517, 1521 (Fed. Cir. 2003) (emphasis added). 
With this backdrop in mind, we are well-placed to appreciate the stunning rise in the Federal Circuit's reliance on dictionaries and similar sources as claim construction tools. We begin with data that give a bird's eye view.

\section{A. The Top-Level View of Dictionary Citation Rates in Patent Cases}

It is not difficult, when surveying the post-Markman claim construction case law, to sense the growing centrality of dictionaries as a claim construction resource. At the same time, one might wonder whether the apparent increase in courts' reliance on dictionaries is simply an artifact of an increase in the overall number of patent decisions or the overall number of claim construction decisions. It is possible, by casting a broad net with text-based searches in electronic case law databases, to approximate some rough-but nevertheless informative-answers to these questions.

We used both broad and a narrow Boolean search strings in Westlaw's district court $(d c t)$ and Federal Circuit court (ctaf) databases to flag both precedential and non-precedential opinions wherein the court likely used a dictionary or similar source to construe a claim term, whether for an infringement or a validity analysis. The search strings are as follows:

Narrow Search-patent! /s claim! /s (constru! or interpret!) /s (dictionar! or encyclopedia! or treatise! or handbook!) and date([restrictor])

Broad Search-patent! / p claim! /p (constru! or interpret!) /p (dictionar! or encyclopedia! or treatise! or handbook!) and date([restrictor])

The Narrow Search string looks for key words that occur within a sentence and the Broad Search string looks for the same key words that occur within a paragraph. We also used an even broader Baseline Search string in the same two databases to flag both precedential and non-precedential opinions where the court likely decided a claim construction question. That search string is thus:

Baseline Search-patent! /p claim! /p (constru! or interpret!) and date([restrictor])

In each of these searches, we adjusted the date restrictor term to reflect the time period of interest, whether a given year or a larger interval.

\section{Comparing the pre- and post-Markman eras}

Before the Federal Circuit's Markman decision, parties could opt to give claim construction questions to the jury. Both district courts and 
the Federal Circuit could review the resulting jury verdicts without elaborate analysis. After Markman, detailed opinions on claim construction questions cannot be avoided, except in the case of summary affirmances on appeal. ${ }^{51}$

Our counts of the baseline number of apparent claim construction opinions issuing from the U.S. district courts (considered as a group) and the Federal Circuit show a sharp increase in claim construction opinions in the nine years since the April 5, 1995 Markman decision, when compared to the number of such opinions issued from 1983 (the first full year of the Federal Circuit's operation) to the day before Markman came down. This increase is all the more notable when one considers that the pre-Markman interval is twenty-five percent larger, measured in months, than the post-Markman interval. Table 1 presents the claim construction opinion counts.

TABLE 1

Number of opinions flagged by the Baseline Search

\begin{tabular}{|l|c|l|}
\cline { 2 - 3 } \multicolumn{1}{c|}{} & 1983 TO Markman & Markman TO 2003 \\
\hline DISTRICT COURTS & 1,284 & 2,478 \\
\hline FEDERAL CIRCUIT & 541 & 1,032 \\
\hline
\end{tabular}

Our counts also show an increase in the share of all claim construction opinions that likely involved use of a dictionary or similar source to construe a claim term. Table 2 presents the counts of district court opinions using both the Narrow Search and Broad Search, expressed both in absolute numbers and as proportions of the Baseline Search results for the same time interval. The proportional data effectively allow comparisons that control for the increase in the overall number of claim construction opinions. Additionally, they show a greater rate of dictionary citation in the post-Markman period. Specifically, the (Narrow Search/Baseline Search) proportion increased more than 27-fold from the pre- to the post-Markman period. The (Broad Search/Baseline Search) proportion increased more than sixfold.

51. See Fed. R. App. P. 36 (mandating that the court must provide a copy of its opinion to all parties to the litigation or a copy of the judgment where no such opinion was written). 
TABLE 2

Number of district court opinions flagged by the Narrow and Broad searches in total and as a percentage of Baseline Search cases

\begin{tabular}{|l|c|c|}
\cline { 2 - 3 } \multicolumn{1}{c|}{} & 1983 TO Markman (\%) & Markman TO 2003(\%) \\
\hline $\begin{array}{l}\text { NARROW } \\
\text { SEARCH }\end{array}$ & $4(0.3 \%)$ & $206(8.3 \%)$ \\
\hline BROAD & & $492(19.9 \%)$ \\
SEARCH & $43(3.3 \%)$ & \\
\hline
\end{tabular}

Table 3 presents analogous counts of Federal Circuit opinions, again expressed in absolute numbers and as proportions of the Baseline Search results. As was true for the district court opinions, the Federal Circuit opinions show a greater rate of dictionary citations in the post-Markman period. Specifically, the (Narrow Search/Baseline Search) proportion increased more than five-fold from the pre- to the post-Markman period. The (Broad Search/Baseline Search) proportion increased more than three-fold.

\section{TABLE 3}

Number of Federal Circuit opinions flagged by the Narrow and Broad searches in total and as a percentage of Baseline Search cases

\begin{tabular}{|l|c|c|}
\cline { 2 - 3 } \multicolumn{1}{c|}{} & 1983 TO Markman $(\%)$ & Markman TO 2003(\%) \\
\hline $\begin{array}{l}\text { NARROW } \\
\text { SEARCH }\end{array}$ & $4(0.7 \%)$ & $39(3.8 \%)$ \\
\hline BROAD & & $130(12.6 \%)$ \\
SEARCH & $18(3.3 \%)$ & \\
\hline
\end{tabular}

In sum, to the extent that our chosen search strings do a good job of capturing actual claim construction output and actual dictionary use within claim construction opinions, the first nine years after Markman (Apr. 1995-Dec. 2003) have witnessed a marked increase in the rate at which the U.S. district courts and the Federal Circuit use dictionaries as claim construction tools.

2. Annual dictionary citation rates from 1993 to 2003

We augmented the aggregated pre- and post-Markman data with annual counts for the U.S. district courts (again considered as a 
group) and the Federal Circuit using the same three search stringsBaseline Search, Narrow Search, and Broad Search-for each year from 1993 to 2003 , inclusive.

Figure 1 presents the results of the Baseline Search for both the district courts and the Federal Circuit. From 1993 to 2003, annual Federal Circuit claim construction opinion output tripled from 49 to 151 cases, while district court opinion output more than tripled from 125 to 406 cases. Not surprisingly, the raw number of opinions from the district courts was greater than the raw number of opinions from the Federal Circuit throughout this period.

\section{FigURE 1}

Annual number of opinions flagged by the Baseline Search from 1993 to 2003

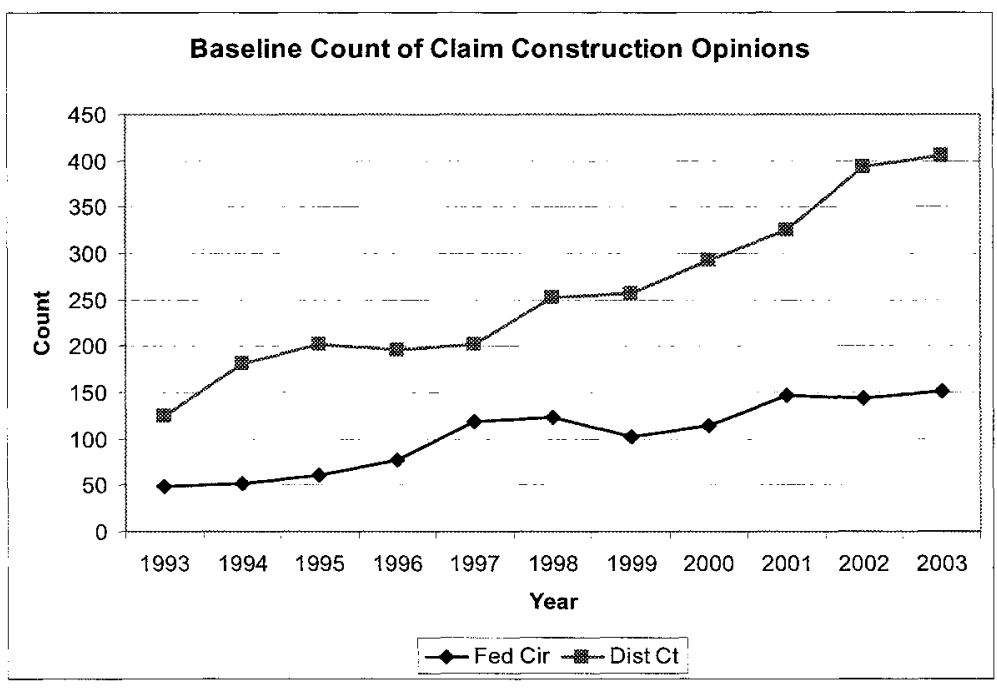

Figure 2 focuses on the results of the Narrow and Broad searches in the district court opinion database. The datapoints in this figure reflect the proportions (Narrow Search/Baseline Search) and (Broad Search/Baseline Search) for each year in the decade. As with the aggregated data discussed above, the use of proportions effectively allows us to control for the rise in dictionary use that is attributable simply to the general rise in claim construction opinion output. Figure 2 shows that the rate of dictionary citation in claim construction opinions in the district courts increased markedly from 1995 to 1999, in both the Narrow Search (from $0.8 \%$ to $11.3 \%$ ) and Broad Search (from $4.8 \%$ to $25.3 \%$ ) categories. After dips in 2000 and 
2001, the 2002 and 2003 levels for both the Narrow Search (10.4\%, $9.1 \%)$ and Broad Search $(22.6 \%, 23.2 \%)$ categories are close to the 1999 level.

FIGURE 2

Annual number of district court opinions flagged by the Narrow and Broad searches, expressed as percentages of Baseline Search cases

\section{District Courts - \% Claim Construction Cases Citing Dictionaries}

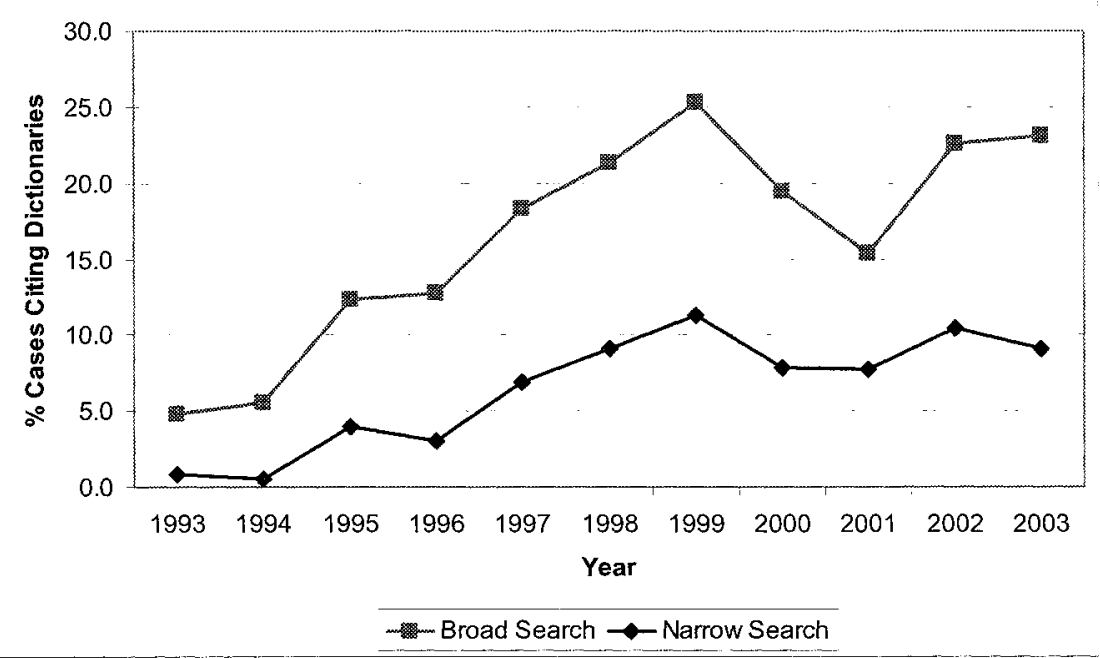

Figure 3, like Figure 2, focuses on annual proportions, but this time in the Federal Circuit. Specifically, Figure 3 shows the dictionary citation rates reflected by the Narrow Search and Broad Search. The Narrow Search proportions show a nearly steady rise, from zero percent in 1993 to $9.3 \%$ in 2003 . In addition, the rise in citation rates from $2.6 \%$ in 2000 to $9.3 \%$ in 2003 represents an increase of over $350 \%$. The Broad Search proportions show two periods of marked increase, the first from $3.3 \%$ in 1995 to $11.3 \%$ in 1998 and the second from $8.7 \%$ in 2000 to $26.5 \%$ in 2003 . The second burst in citation rates is especially sharp, with a one-year jump from $14.6 \%$ in 2002 to $26.5 \%$ in 2003 . It is interesting to note, in connection with this tripling in annual dictionary citation rates from 2000 to 2003 in the Broad Search and the more-than-tripling in the Narrow Search, that two of the six most active claim construction dictionary citers on the 
Federal Circuit revealed by our data, Judges Dyk and Linn, began their active service on the court in the first half of $2000 .^{52}$

FIGURE 3

Annual number of Federal Circuit opinions flagged by the Narrow and Broad searches, expressed as a percentage of Baseline Search cases

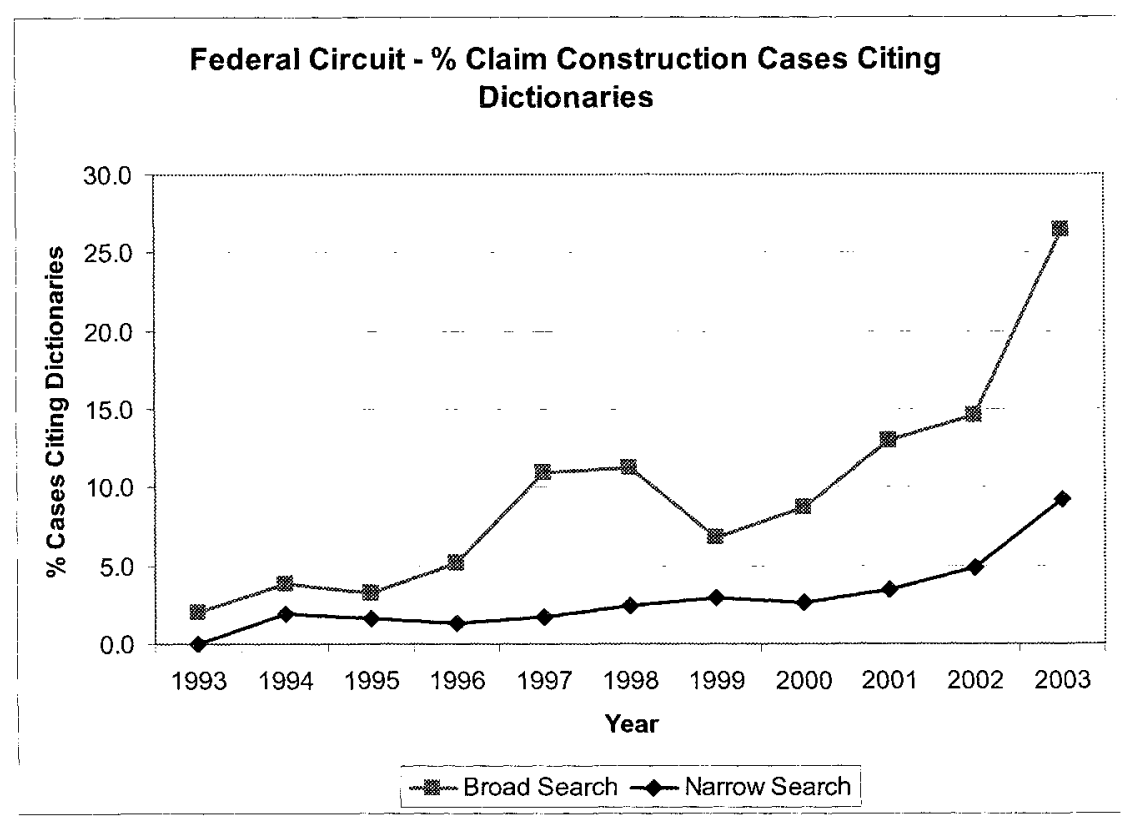

In sum, to the extent that our chosen search strings provide good measures of claim construction and dictionary reliance activity (an important qualification on the data presented in this section of the paper), the period from 1993 to 2003 witnessed marked increases in the annual rates at which the U.S. district courts and the Federal Circuit used dictionaries as claim construction tools. Indeed, at the Federal Circuit, the 2000 to 2003 time period saw a dramatic increase in dictionary citation rates, tripling from $8.7 \%$ to $26.5 \%$ in the (Broad Search/Baseline Search) proportions and more than tripling from $2.6 \%$ to $9.3 \%$ in the (Narrow Search/Baseline Search) proportions. The impression of more frequent reliance on dictionaries in claim

52. Infra Tbl. 7, App. B. Judge Linn began active service on January 1, 2000 and Judge Dyk began active service on June 9,2000. U.S. COURT OF APPEALS FOR THE FEDERAL CIRCUIT, JUDICIAL BIOGRAPIIIES, at www.fedcir.gov/judgbios.html (last modified Jan. 25, 2005) (on file with the American University Law Review). 
construction opinions should not be dismissed as an artifact of the general increase in claim construction opinions.

To achieve a deeper understanding of dictionary citation rate growth, one must examine in detail the Federal Circuit cases wherein the court used one or more dictionaries to help determine the meaning of a word in a contested patent claim. After touching briefly on three milestones in the Federal Circuit's claim construction jurisprudence-Markman, Vitronics, and Telegenix-we present data from just such a detailed examination.

\section{B. "Unbiased Reflections of Common Understanding"}

We know that one factor driving the Federal Circuit to use dictionaries in claim construction more often is the heavy presumption in favor of giving a claim term its ordinary meaning to those of skill in the pertinent art, combined with the identification of ordinary meaning with dictionary content. ${ }^{53}$ As an additional backdrop against which to assess the data from our detailed review of all dictionary-citing Federal Circuit cases from April 1995 to June 2004 , it is helpful to explore the Federal Circuit's avowed rationale for relying on dictionaries. The rationale has evolved, shifting from a stance rooted in the need generalist judges have to learn background information about the disputed technology, to one rooted in the greater neutrality of publicly available reference sources that predate a given dispute. The shifts in rationale are readily apparent upon close review of a small number of milestone claim construction cases, beginning with the Markman case.

\section{Markman v. Westview Instruments}

The Federal Circuit's en banc decision in Markman v. Westview Instruments, Inc. ${ }^{54}$ is best known for its holding that "the court"-that is, the judge, not the jury-"has the power and obligation to construe as a matter of law the meaning of language used in the patent claim." However, just as important as this bare holding is the Federal Circuit's assessment in that case of the sources on which judges should rely when construing disputed patent claim terms.

In keeping with many of its prior cases, the court began with a focus on sources internal to the patent document itself, including the claims in the patent, the specification that supports those claims (also

53. See supra notes $38-50$ and accompanying text.

54. 52 F.3d 967, 34 U.S.P.Q.2d (BNA) 1321 (Fed. Cir. 1995) (en banc), affd, 517 U.S. 370 (1996).

55. Id. at 979, 34 U.S.P.Q.2d (BNA) at 1329. 
called the written description of the patent), and the patent's prosecution history before the Patent Office. ${ }^{56}$ The court then discussed sources aimed specially at helping a generalist judge learn enough about the pertinent technological field to construe the disputed claim language properly, grouping the materials under the rubric "extrinsic evidence." According to the court,

[e]xtrinsic evidence consists of all evidence external to the patent and prosecution history, including expert and inventor testimony, dictionaries, and learned treatises. This evidence may be helpful to explain scientific principles, the meaning of technical terms, and terms of art that appear in the patent and prosecution history. Extrinsic evidence may demonstrate the state of the prior art at the time of the invention. It is useful to show what was then old, to distinguish what was new, and to aid the court in the construction of the patent. $^{58}$

The court thus approved extrinsic evidence, including dictionaries and treatises, as claim construction resources while at the same time tethering use of such materials to the need for specialized technological information.

Time has weakened this link between reliance on dictionaries and the need for specialized information. The next case was the first step in the attenuation process.

2. Vitronics Corp. v. Conceptronic, Inc.

A little over a year after its own Markman decision, and shortly after the Supreme Court's affirmance of Markman, the Federal Circuit handed down an opinion that drew special attention to the utility of dictionaries in claim construction. The case is Vitronics Corp. $v$. Conceptronic, Inc., ${ }^{59}$ and it "place[s] technical treatises and dictionaries near the top of the extrinsic evidence hierarchy." 60

In Vitronics, the Federal Circuit reversed a trial court's erroneous construction of the phrase "solder reflow temperature" in a patent claim directed to a method for mounting chips on circuit boards. ${ }^{61}$ The undermining vice in the trial court's approach to claim

56. Id., 34 U.S.P.Q.2d (BNA) at 1329.

57. Id. at 979-81, 34 U.S.P.Q.2d (BNA) at 1329-31.

58. Markman, 52 F.3d at 980,34 U.S.P.Q.2d (BNA) at 1330 (emphasis added) (internal quotations and citations omitted).

59. 90 F.3d 1576, 39 U.S.P.Q.2d (BNA) 1573 (Fed. Cir. 1996).

60. Ben Hattenbach, Chickens, Eggs and Other Impediments to Escalating Reliance on Dictionaries in Patent Claim Construction, 85 J. PAT. \& TRADEMARK OFF. SOC'Y 181, 183 (2003); see also Edward G. Poplawski, Selection and Use of Experts in Patent Cases, 27 AIPLA Q.J. 1, 29 (1999) (opining that "Vitronics established a hierarchy for types of extrinsic evidence").

61. Vitronics, 90 F.3d at 1578-79, 39 U.S.P.Q.2d (BNA) at 1573-74. 
construction was undue reliance on the testimony of the accused infringers' expert witness. ${ }^{62}$ In explaining the trial court's error, the Federal Circuit rehearsed the list of permissible extrinsic sources"expert testimony, inventor testimony, dictionaries, and technical treatises and articles." ${ }^{, 3}$ It then passed beyond mere rehearsal in a footnote-footnote 6 -that has changed the face of claim construction: ${ }^{64}$

Although technical treatises and dictionaries fall within the category of extrinsic evidence, as they do not form a part of an integrated patent document, they are worthy of special note. Judges are free to consult such resources at any time in order to better understand the underlying technology and may also rely on dictionary definitions when construing claim terms, so long as the dictionary definition does not contradict any definition found in or ascertained by a reading of the patent documents. ${ }^{65}$

Two important things happened here. First, the court directly encouraged judges to consult dictionaries and similar sources to learn about the technology at issue in a dispute, stating they are available "at any time." ${ }^{66}$ Second, and quite apart from the 'technology backgrounder' point, the court approved "rel[iance] on dictionary definitions when construing claim terms," ${ }^{, 67}$ foreshadowing

62. See id. at 1581, 39 U.S.P.Q.2d (BNA) at 1575 (describing testimony from defense expert, Dr. Rothe); $i d$. at 1585, 39 U.S.P.Q.2d (BNA) at 1578 ("Unfortunately, here the trial judge did use the extrinsic evidence to vary or contradict the manifest meaning of the claims.").

63. Id. at 1584, 39 U.S.P.Q.2d (BNA) at 1578 .

64. The Federal Circuit, in the time between the Vitronics case and the Telegenix case (the next milestone case in this line of development), has at least nine times squarely relied on footnote 6 in Vitronics to support its use of dictionaries as claim construction tools, including in Telegenix itself. See, e.g., Tex. Digital Sys., Inc. v. Telegenix, Inc., 308 F.3d 1193, 1202, 64 U.S.P.Q.2d (BNA) 1812, 1818 (Fed. Cir. 2002); Union Carbide Chems. \& Plastics Tech. Corp. v. Shell Oil Co., 308 F.3d 1167, 1177 \& n.4, 64 U.S.P.Q.2d (BNA) 1545, 1552 n.4 (Fed. Cir. 2002); CCS Fitness, Inc. v. Brunswick Corp., 288 F.3d 1359, 1366, 62 U.S.P.Q.2d (BNA) 1658, 1662 (Fed. Cir. 2002); Bell Atl. Network Servs., Inc. v. Covad Communications Group, Inc., 262 F.3d 1258, 1267, 59 U.S.P.Q.2d (BNA) 1865, 1870 (Fed. Cir. 2001); Dow Chem. Co. v. Sumitomo Chem. Co., Ltd., 257 F.3d 1364, 1373, 59 U.S.P.Q.2d (BNA) 1609, 1614 (Fed. Cir. 2001); Optical Disc Corp. v. Del Mar Avionics, 208 F.3d 1324, 1334-35, 54 U.S.P.Q.2d (BNA) 1289, 1295 (Fed. Cir. 2000); Cybor Corp. v. FAS Techs., Inc., 138 F.3d 1448, 1459, 46 U.S.P.Q.2d (BNA) 1169, 1177 (Fed. Cir. 1998) (en banc); Circle R, Inc. v. Trail King Indus., Inc., 21 Fed. Appx. 894, 898 \& n.3 (Fed. Cir. 2001); Rival Co. v. Sunbeam Corp., Nos. 98-1198, 98-1199, 1999 WL 96416, at *5 (Fed. Cir. Feb. $23,1999)$.

65. Vitronics, 90 F.3d at 1584 n.6, 39 U.S.P.Q.2d (BNA) at 1578 n.6 (emphasis added).

66. Id., 39 U.S.P.Q.2d. (BNA) at 1578.

67. Id., 39 U.S.P.Q.2d. (BNA) at 1578. 
the identification of dictionary definition with ordinary meaning that has since become so pronounced in the court's cases. ${ }^{68}$

Why this special solicitude for dictionaries in Vitronics? The court highlighted the utility of such sources by contrasting them with the partisan slant that expert witnesses provide-and remember, the root of the trial court's error in this case was over-reliance on inapposite expert testimony. ${ }^{69} \quad$ Specifically, after distinguishing "expert testimony ... on the proper construction of a disputed claim term" from background "testimony on the technology," the court urged that

prior ant documents and dictionaries, although to a lesser extent, are more objective and reliable guides [than expert testimony]. Unlike expert testimony, these sources are accessible to the public in advance of litigation. They are to be preferred over opinion testimony, whether by an attorney or artisan in the field of technology to which the patent is directed. Indeed, opinion testimony on claim construction should be treated with the utmost caution, for it is no better than opinion testimony on the meaning of statutory terms. ${ }^{71}$

Opinion testimony on the meaning of a disputed claim term is thus inherently disfavored, relative to publicly available "objective" documents, such as prior art references and dictionaries that predate the litigation. It warrants a judge's "utmost caution." "72 The court's

68. See supra notes 45-49 and accompanying text.

69. Vitronics, 90 F.3d at 1581,39 U.S.P.Q.2d (BNA) at 1575.

70. Id. at 1585, 39 U.S.P.Q.2d (BNA) at 1579 . The court continues to approve the use of expert testimony to teach trial judges background information about the pertinent technology. See, e.g., Key Pharms. v. Hercon Labs. Corp., 161 F.3d 709, 716, 48 U.S.P.Q.2d (BNA) 1911, 1917 (Fed. Cir. 1998) (stating that "trial courts generally can hear expert testimony for background and education on the technology implicated by the presented claim construction issues, and trial courts have broad discretion in this regard"). The court also approved a district court's decision, in a case involving highly complex microprocessor technology, to appoint a "technical advisor" to help the court better cope with the scientific and technical information in the case. TechSearch, L.L.C. v. Intel Corp., 286 F.3d 1360, 1377-79, 62 U.S.P.Q.2d (BNA) 1449, 1460-63 (Fed. Cir. 2002).

71. Vitronics, 90 F.3d at 1585, 39 U.S.P.Q.2d (BNA) at 1579 (emphasis added).

72. Id., 39 U.S.P.Q.2d (BNA) at 1579 . The court has recently commented on this need for objectivity in claim construction:

The inquiry into the meaning that claim terms would have to a person of skill in the art at the time of the invention is an objective one. This being the case, $a$ court looks to those sources available to the public that show what a person of skill in the art would have understood disputed claim language to mean. Those sources include the words of the claims themselves, the remainder of the specification, the prosecution history, and extrinsic evidence concerning relevant scientific principles, the meaning of technical terms, and the state of the art.

Innova/Pure Water, Inc. v. Safari Water Filtration Sys., Inc., 381 F.3d 1111, 1116, 72 U.S.P.Q.2d (BNA) 1001, 1005 (Fed. Cir. 2004) (emphasis added); see also Bell \& Howell Document Mgmt. Prods. Co. v. Altek Sys., 132 F.3d 701, 706, 45 U.S.P.Q.2d (BNA) 1033, 1038 (Fed. Cir. 1997) ("Once a dispute over claim construction arises, 'experts' should also not be heard to inject a new meaning into terms that is 
central message here, in combination with footnote 6 , is unmistakable: dictionaries are better than expert testimony.

Vitronics, like Markman, links the use of dictionaries to the need for specialized technological information. Unlike Markman, however, Vitronics also approves the use of dictionaries to define claim terms, praising these sources as superior to expert witnesses because they are "more objective and reliable guides." This theme-that dictionaries are preferred because they are not avowedly partisan in content-took center stage in the next milestone case.

\section{Texas Digital Systems, Inc. v. Telegenix, Inc.}

A little over six years after Vitronics, the Federal Circuit handed down its decision in Texas Digital Systems, Inc. v. Telegenix, Inc., ${ }^{73}$ which reframed its rationale for using dictionaries in claim construction. The court had, of course, continued to use dictionaries after Vitronics to help construe claims. ${ }^{74}$ In Telegenix, however, the court discussed the benefits of recourse to dictionaries more elaborately than in any other case. One commentator has called it "a momentary high water mark" in the line of dictionary cases. ${ }^{75}$

Before plunging into detailed analyses of the eleven separate claim construction disputes requiring resolution, ${ }^{76}$ of which only three used

inconsistent with what the inventor set forth in his or her patent and communicated, first to the patent examiner and ultimately to the public. Patents should be interpreted on the basis of their intrinsic record, not on the testimony of such afterthe-fact 'experts' that played no part in the creation and prosecution of the patent.").

73. 308 F.3d 1193, 64 U.S.P.Q.2d (BNA) 1812 (Fed. Cir. 2002).

74. In two cases that Hattenbach highlights, see supra note 60 , at 186 , the Federal Circuit emphasized the vital role dictionaries can play in providing evidence of a word's ordinary meaning. See Union Carbide Chems. \& Plastics Tech. Corp., 308 F.3d 1167, 1177 n.4, 64 U.S.P.Q.2d (BNA) 1545, 1552 n.4 (Fed. Cir. 2002) ("Although technically a form of extrinsic evidence, dictionaries hold a special place in claim construction, and judges 'may... rely on dictionary definitions when construing claim terms, so long as the dictionary definition does not contradict any definition found in or ascertained by the reading of the patent document..") (quoting Vitronics Corp. v. Conceptronic, Inc., 90 F.3d 1576, 1584 n.6 (Fed. Cir. 1996)); Dow Chem. Co. v. Sumitomo Chem. Co., 257 F.3d 1364, 1373, 59 U.S.P.Q.2d (BNA) 1609, 1614 (Fed. Cir. 2001) ("[T]echnical terms often have an "ordinary meaning' as understood by one of ordinary skill in the art, although these same terms may not be readily familiar to a judge, or may be familiar only in a different context. Thus, in determining the ordinary meaning of a technical term, courts are free to consult scientific dictionaries and technical treatises at any time.").

75. Hattenbach, supra note 60 , at 181 .

76. See Telegenix, 308 F.3d at 1205-16, 64 U.S.P.Q.2d (BNA) at 1820-29 (setting out the eleven disputed claim terms, including "repeatedly substantially simultaneously activating," "selectively controlling the durations of the time intervals of activation," "color control means," "display areas" and "background areas," "display areas arranged in a pattern," "means for selectively activating said display light sources," "converter means," and "control means for selectively coupling said light sources"). 
a dictionary to help construe the term, ${ }^{77}$ the Telegenix court provided a spirited encomium to dictionary use. ${ }^{78}$ Specifically, and with greater emphasis than Vitronics, the court identified the benefit of dictionaries with their freedom from the taint of litigation advocacy masquerading as expertise. According to the court,

[d]ictionaries, encyclopedias, and treatises, publicly available at the time the patent is issued, are objective resources that serve as reliable sources of information on the established meanings that would have been attributed to the terms of the claims by those of skill in the art. Such references are unbiased reflections of common understanding not influenced by expert testimony or events subsequent to the fixing of the intrinsic record by the grant of the patent, not colored by the motives of the parties, and not inspired by litigation. Indeed, these materials may be the most meaningful sources of information to aid judges in better understanding both the technology and the terminology used by those skilled in the art to describe the technology. ${ }^{79}$

77. See id. at 1206, 1209, 64 U.S.P.Q.2d (BNA) at 1821, 1823 (construing claim limitation "repeatedly substantially simultaneously activating" with the aid of MODERN DICTIONARY OF ELECTRONICS (6th ed. 1984) and "display area" and "background area" with the aid of ILLUSTRATED DICTIONARY OF ELECTRONICS (3d ed. 1985)).

78. Id. at 1202-05, 64 U.S.P.Q.2d (BNA) at 1818-20.

79. Id. at 1202-03, 64 U.S.P.Q.2d (BNA) at 1818 (emphasis added). If one were to take "unbiased" in this passage to refer to the complete absence of prejudice or personal interest, the Federal Circuit has stumbled badly here. Dictionary-writing is a decidedly human enterprise; the people who write dictionaries, like the rest of us, bring their individual judgments and points of view to their work. As Sidney Landau, an eminent lexicographer with over forty years' experience, has stated, "[e]very established dictionary reflects, however it may strive to be impartial, the prevailing biases of its times, because the biases often inhere in the very manner of expression used in its definitions." LANDAU, supra note 2, at 421. Landau argues that "[d]ictionaries act as a conservative force on the language because they tend to overrepresent the volume of conservative speech and writing, which is that of the educated classes, and underrepresent the volume of speech and writing by and for people who are relatively uneducated." Id. at 207. For example, Landau discusses the range of approaches, across books and over time, to the inclusion of sexual and scatological taboo words in dictionaries. Id. at 228-31; see also HENRI BÉJOINT, MODERN LEXICOGRAPHY: AN INTRODUCTION 124-36 (2d ed. 2000) (discussing the range of ways in which dictionaries reflect the ideology of the dominant culture); Anne Curzan, The Compass of the Vocahulary, in LEXICOGRAPHY AND THE OED: PIONEERS IN The UnTRODDEN Forest 96, 96 (Lynda Mugglestone ed., 2000) (commenting that "[t]he apparent objectivity of dictionaries rests on a series of subjective judgments" because "dictionaries and dictionary makers define what constitutes 'the language' as much as they do any individual word in the lexicon"). In a similar vein, David Foster Wallace, a successful novelist and astute observer of literary culture, recently observed that "claims to objectivity in language study are now the stuff of jokes and shudders." David Foster Wallace, Tense Present: Democracy, English, and the Wars Over Usage, HARPER'S MAG., Apr. 1, 2001, at 39, 46. He continues that " $[\mathrm{t}]$ o presume that dictionary-making can somehow avoid or transcend ideology is simply to subscribe to a particular ideology, one that might aptly be called Unbelievably Naive Positivism." Id.

If, however, one takes "unbiased" in the narrower sense of "disinterested" that the passage as a whole suggests-namely, not reflecting any stake in the outcome of the case at hand-then the Federal Circuit is on solid ground. An expert witness, 
And gone is the careful parsing of extrinsic from intrinsic evidence. The court rejected categorizing dictionaries as "extrinsic evidence" or even a "special form of extrinsic evidence." dictionaries are, quite literally, in a category by themselves.

The court also quite openly equates a word's ordinary meaning with its dictionary definition, moving from mention of "a 'heavy presumption' that" claim words "have the ordinary meaning that would be attributed to those words by persons skilled in the relevant art," ${ }^{81}$ at the outset of the discussion, to "the presumption in favor of a dictionary definition" not surprising that, at the conclusion of its general discussion of dictionary use, the court suggests a standard claim construction procedure in which using relevant dictionaries to obtain possible meanings that would have been attributed to the words of the claims by those skilled in the art is effectively a universal first step. ${ }^{83}$ Markman's more narrowly drawn link between resort to dictionaries and the occasional need for specialized technological information has far receded.

The road from Markman to Telegenix, then, is one from the occasional reference to a specialized dictionary of technological arcana to routine reliance upon numerous definitions from neutral reference sources. Dictionaries admittedly have not assumed this central role without some controversy. ${ }^{84}$ The court's decision in

retained by a party in a particular dispute, surely has a stake in the success with which she persuades the decisionmaker in the case and crafts her testimony accordingly; hence the common knock on expert witnesses is that too often they are biased mouthpieces for the parties who hire them. See, e.g., Richard A. Epstein, Judicial Control Over Expert Testimony: Of Deference and Education, 87 Nw. U. L. REv. 1156, $1162-$ 65 (1993). By contrast, a team of professional dictionary writers, who toiled at their work before the patent in dispute (much less the lawsuit about it) ever existed, almost certainly cannot have had any stake in the scope of a later-issued patent or the outcome of a later-filed infringement case as they wrote the definitions that a dictionary contains. Dictionaries are, for the most part, published in the hopes of turning a profit, and they cannot do so unless they attract as wide a range of consumers as possible; writing skewed definitions to curry favor with a single individual or firm would, in these circumstances, be self-defeating.

80. Telegenix, 308 F.3d at 1203 , 64 U.S.P.Q.2d (BNA) at 1819.

81. Id. at 1202,64 U.S.P.Q.2d (BNA) at 1817.

82. Id. at 1204, 64 U.S.P.Q.2d (BNA) at 1819.

83. Id. at 1205,64 U.S.P.Q.2d (BNA) at 1820. However valuable a first step in claim construction, consulting a dictionary can never be the final step. See supra note 50 and accompanying text.

84. For example, the court occasionally expresses some skepticism about reliance on dictionaries. See Kinik Co. v. Int'l Trade Comm'n, 362 F.3d 1359, 1365, 70 U.S.P.Q.2d (BNA) 1300, 1304-05 (Fed. Cir. 2004) (Newman, J.) (indicating that a court should not rely on a dictionary to provide the meaning of a common word where the working definition of that word within a patent document is peculiar to the context of that document); AFG Indus., Inc. v. Cardinal IG Co., 239 F.3d 1239, 1248, 57 U.S.P.Q.2d (BNA) 1776, 1783 (Fed. Cir. 2001) (Michel, J.) (emphasizing 
Telegenix, however, hails dictionaries as the primary tools for identifying ordinary meanings of disputed claim terms as they would be understood by those skilled in the art-a step that must be taken to resolve any claim construction dispute, given the heavy presumption in favor of ordinary meaning for the words in a claim.

The change in rhetoric from dictionary as occasional reference (Markman) to basic tool (Telegenix) accompanies a correlative change in the court's avowed rationale for using dictionaries, from one rooted in the need to educate the court about technology to one rooted in the need to establish a word's ordinary meaning with a neutral resource. Which rationale, one might query, better comports with the Federal Circuit's actual use of dictionaries? Does the court, as the Markman rationale might lead one to predict, use specialized dictionaries more often than general purpose English language sources? Or rather does the court, as the Telegenix rationale might lead one to predict, use general purpose English language sources just as often-or perhaps even more often than-specialized sources, for the simple reason that the quality that makes reference sources attractive is their neutrality rather than any specialized content? Only detailed data on the Federal Circuit's actual use of dictionaries can answer these questions.

\section{The Federal Circuit's Use of Dictionaries for Claim Construction}

Our top-level data show that, while the number of written Federal Circuit claim construction decisions roughly tripled from 1993 to

that courts should turn to dictionaries only when patent documents fail to define terms of art, particularly since standard dictionaries can fail to distinguish two words treated as distinct within the patent documents); Toro Co. v. White Consol. Indus., Inc., 199 F.3d 1295, 1299-1300, 53 U.S.P.Q.2d (BNA) 1065, 1067-68 (Fed. Cir. 1999) (Newman, J.) (suggesting that the general nature of dictionary definitions renders dictionaries unable to settle disputes over the specific scientific meanings of words in patent documents); Anderson v. Int'l Eng'g \& Mfg., Inc., 160 F.3d 1345, 1348-49, 48 U.S.P.Q.2d (BNA) 1631, 1633-34 (Fed. Cir. 1998) (Newman, J.) (noting that where dictionaries provide more than one meaning for the same word, the technical meaning of the word must be taken from the context of the patent documents at issue); Multiform Desiccants, Inc. v. Medzam, Ltd., 133 F.3d 1473, 1478, 45 U.S.P.Q.2d (BNA) 1429, 1433 (Fed. Cir. 1998) (Newman, J.) (cautioning courts against using dictionaries to provide "legal, not linguistic, significance" to patent document terms); see also Housey Pharms., Inc. v. AstraZeneca UK Ltd., 366 F.3d 1348, 1356-60, 70 U.S.P.Q.2d (BNA) 1641, 1647-50 (Fed. Cir. 2004) (Newman, J., dissenting) (criticizing both the heavy presumption in favor of ordinary meaning and the use of dictionaries as claim construction tools). Judge Newman authored all but one of the court's opinions expressing skepticism about dictionary use, and, as our detailed data show, Judge Newman used dictionaries as claim construction tools only twice from April 1995 to June 2004. See infra Tbl. 7, App. B. Among the judges still in active service on the court, only Chief Judge Mayer used dictionaries on fewer occasions. Id. 
2003, the rate at which the Federal Circuit appeared to cite dictionaries in aid of its claim construction analysis increased about nine-fold in the same period. ${ }^{85}$ And a close reading of the Federal Circuit's post-Markman caselaw shows that the court's rationale for using reference sources such as dictionaries shifted from a focus on gaining helpful background information about disputed technology (in Markman and, to a lesser extent, in Vitronics), to a focus on the greater neutrality offered by such reference works (in Telegenix). ${ }^{86}$ Which rationale, then, better comports with the Federal Circuit's use of dictionaries? Our data show that the Telegenix rationale explains the court's actual use of dictionaries far better than does the Markman rationale.

\section{Methodology}

We created a dataset describing all occasions from April 5, 1995 to June 30, 2004, where the Federal Circuit used one or more dictionaries or similar sources to help define a word or phrase in a contested patent claim. ${ }^{87}$ The unit of analysis in this dataset is not an individual case; rather, it is the use of a reference source to define a word or phrase in a claim. Thus, for example, the case captioned Yamaha Corp. v. ESS Technology, Inc., ${ }^{88}$ involving a dispute over the claim limitation "a stored waveshape table," yielded three entries for our dataset-one for each word that the court defined with the aid of a dictionary (i.e., "stored," "waveshape," and "table"). Similarly, the case captioned Zygo Corp. v. Wyko Corp.," involving a dispute over the claim limitation "coherence length of the beam," yielded one entry for our dataset-an entry reflecting the phrase that the court defined by consulting a reference source (i.e., "coherence length"). ${ }^{91}$ It is also important to note that we counted only majority opinions for the court; individual judges' citations to dictionaries in concurring or dissenting opinions are not counted here.

To create this dataset, we first used broad searches to flag all arguable candidates in Westlaw's database of Federal Circuit opinions

85. See supra Figure 1 (showing a three-fold increase in claim construction decisions), Figure 3 and accompanying text (showing that Broad Search proportion increased from $3.3 \%$ in 1993 to $26.5 \%$ in 2003 ).

86. See supra Part I.B.

87. See infra App. C (providing the dataset).

88. No. 95-1362, 1996 WL 146499 (Fed. Cir. Mar. 29, 1996).

89. See infra App. C, at rows 12-14.

90. 79 F.3d 1563, 38 U.S.P.Q.2d (BNA) 1281 (Fed. Cir. 1996).

91. Id. at 1565 \& n.1, 38 U.S.P.Q.2d (BNA) at 1282 \& n.1; see infra App. C, at row 17. 
(ctaf). ${ }^{92}$ With the help of research assistants, we read the cases to winnow the group to those that arguably involved use of at least one dictionary or similar source to help define a word in a disputed patent claim. At that stage, we read the smaller group of cases in close detail, collecting the relevant information about each occasion where the Federal Circuit did, in fact, use a dictionary to help define a contested claim term. The dataset in Appendix $C$ describes each of these occasions. We identified only four cases (two precedential and two nonprecedential) in which the Federal Circuit first identified dictionary definitions for claim words with specificity and then expressly rejected any reliance on the dictionaries. ${ }^{93}$ We excluded these cases from our dataset. We also identified, and excluded from the dataset, ten cases in which the Federal Circuit used a dictionary to define a word from the written description portion of the patent, rather than from a claim. ${ }^{94}$

\section{Results}

From April 5, 1995 to June 30, 2004, the Federal Circuit used one or more dictionaries to help construe a disputed claim term 209 times. $^{95}$ Table 4 presents annual totals, separating precedential from

92. We used search terms such as (patent! and (infringe! or valid!) and (dictionar! or treatise! or encyclopedia! or handbook!)) and (patent! and claim! and dictionar!). Because we are analyzing the reasons the court provides in its written decisions, our data do not include-and we know nothing about the role of dictionaries in-cases in which the Federal Circuit summarily affirmed the trial court's claim construction without writing its own opinion.

93. See Kumar v. Ovonic Battery Co., 351 F.3d 1364, 1367-68, 1372 \& nn.3-5, 69 U.S.P.Q.2d (BNA) 1220, 1222-23, 1226 \& nn.3-5 (Fed. Cir. 2003); AFG Indus., Inc. v. Cardinal IG Co., 239 F.3d 1239, 1247-49, 57 U.S.P.Q.2d (BNA) 1776, 1782-84 (Fed. Cir. 2001), vacated by 375 F.3d 1367, 71 U.S.P.Q.2d (BNA) 1678 (Fed. Cir. 2004); Ultratech Stepper, Inc. v. ASM Lithography, Inc., 97 Fed. Appx. 914, 919-20 (Fed. Cir. 2004); Lizardtech, Inc. v. Earth Resource Mapping, Inc., 35 Fed. Appx. 918, 924 (Fed. Cir. 2002).

94. See Novartis Pharms. Corp. v. Abbott Labs., 375 F.3d 1328, 1335-36, 71 U.S.P.Q.2d (BNA) 1650, 1656-57 (Fed. Cir. 2004); 3M Innovative Props. Co. v. Avery Dennison Corp., 350 F.3d 1365, 1371, 69 U.S.P.Q.2d (BNA) 1050, 1054-55 (Fed. Cir. 2003); Genzyme Corp. v. Transkaryotic Therapies, Inc., 346 F.3d 1094, 1099, 68 U.S.P.Q.2d (BNA) 1596, 1600 (Fed. Cir. 2003); Amgen Inc. v. Hoechst Marion Roussel, Inc., 314 F.3d 1313, 1345, 65 U.S.P.Q.2d (BNA) 1385, 1408-09 (Fed. Cir. 2003); Electro Scientific Indus., Inc. y. Dynamic Details, Inc., 307 F.3d 1343, 1350, 64 U.S.P.Q.2d (BNA) 1781, 1785 (Fed. Cir. 2002); Kopykake Enters., Inc. v. Lucks Co., 264 F.3d 1377, 1382, 60 U.S.P.Q.2d (BNA) 1124, 1126-27 (Fed. Cir. 2001); In re Baker Hughes Inc., 215 F.3d 1297, 1303, 55 U.S.P.Q.2d (BNA) 1149, 1153 (Fed. Cir. 2000); Lizardtech, 35 Fed. Appx. at 924; G\&S Metal Prods. Co. v. Ekco Housewares, Inc., 152 F.3d 944, Nos. 97-1188, 97-1210, 1998 WL 121472, at *4 (Fed. Cir. Mar. 17, 1998); Storz Instrument Co. v. Alcon Labs., Inc., 135 F.3d 777, No. 97-1149, $1998 \mathrm{WL}$ 50947 , at $* 7$ (Fed. Cir. Jan. 26, 1998). The Novartis case, decided in July 2004, is also outside the temporal scope of this study.

95. See infra App. C. 
nonprecedential decisions. Annual dictionary use increased by a factor of fourteen from 1995 to 2003.

\section{TABLE 4}

Number of times the Federal Circuit relied on at least one dictionary definition of a patent claim word to help construe an element of that claim

\begin{tabular}{|l|l|l||l|}
\hline YEAR & $\begin{array}{l}\text { Published } \\
\text { Decision }\end{array}$ & $\begin{array}{l}\text { Unpublished } \\
\text { Decision }\end{array}$ & TOTAL \\
\hline $1995^{*}$ & 2 & 1 & 3 \\
\hline 1996 & 9 & 5 & 14 \\
\hline 1997 & 8 & 6 & 14 \\
\hline 1998 & 4 & 5 & 9 \\
\hline 1999 & 4 & 6 & 10 \\
\hline 2000 & 13 & 10 & 23 \\
\hline 2001 & 19 & 9 & 28 \\
\hline 2002 & 22 & 10 & 32 \\
\hline 2003 & 34 & 8 & 42 \\
\hline $2004^{*}$ & 25 & 9 & 34 \\
\hline TOTAL & 139 & 69 & 209 \\
\hline
\end{tabular}

* Partial year

In using dictionaries to help construe claim words 209 times, the Federal Circuit used 268 individually identified sources, i.e., 1.28 sources per term. ${ }^{96}$ Specifically, the Federal Circuit relied on one, and only one, source 167 times $(79.9 \%)$, on two sources thirty-three times $(15.8 \%)$, on three sources four times $(1.9 \%)$, on four sources three times $(1.4 \%)$, and on five sources and six sources one time each $(0.5 \%)$.

General purpose English language sources dominate the dataset. ${ }^{97}$ Specifically, out of the 268 sources used, the court used $189(70.5 \%)$ general purpose English language sources and seventy-nine (29.5\%) specialized sources. Tables 5 and 6, contained in Appendix B, list all the general purpose English language sources cited and all the specialized sources cited, respectively, including the number of times the court cited each source. Of the six most-often cited sources, ${ }^{98}$ the top five are general purpose sources.

96. See infra App. C.

97. See infra Tbls. 5-6, App. B.

98. These are Webster's Third New International Dictionary (cited sixty-eight times); 
Several facts stand out immediately upon review of Tables 5 and 6. First, citations to Webster's Third New International Dictionary (Webster's Third) dominate the dataset. The court cited various printings of Webster's Third sixty-eight times; ${ }^{99}$ Webster's Third was originally published in 1961 and is still Merriam-Webster's flagship dictionary. This represents $25.4 \%$ of all citations to any source (general or specialized), and $36.0 \%$ of all citations to a general purpose English language source. The Federal Circuit is, in this respect, like the Supreme Court, where Webster's Third New International Dictionary and its predecessor, Webster's New International Dictionary, Second Edition, are the two most frequently cited dictionaries. ${ }^{100}$

Second, the Merriam-Webster family of dictionaries-comprising Webster's Third, its two immediate predecessors, and four different editions of its New Collegiate series (all of which share a common editorial core with the New International series) ${ }^{101}$-accounts for $38.4 \%$ of the citations to any source, and $54.5 \%$ of the citations to any general purpose source. Considering families of editorially related dictionaries, Houghton Mifflin's American Heritage Dictionary family takes second place with twenty four citations ( $9.0 \%$ of all citations). ${ }^{102}$

Webster's Ninth New Collegiate Dictionary (cited eighteen times); Webster's New World Dictionary (cited fifteen times); American Heritage Dictionary (cited twelve times); Webster's II New Riverside University Dictionary (cited ten times); McGraw-Hill Dictionary of Scientific and Technical Terms (cited nine times). See infra Tbls. 5-6, App. B.

99. See infra App. C.

100. Lexicon Fortress, supra note 8 , at 262-63 (reporting statistics); id. at 533-55 (listing cases); Lexicon Remains, supra note 8, at 52 (summarizing results); id. at 66-68 (listing cases).

101. See Webster's NinTh New COllegiate Dictionary 6 (1985) (describing itself as "the latest in the Collegiate line of Merriam-Webster dictionaries which began in 1898"); WEBSTER's SEVENTH NEW COLLEGIATE DICTIONARY 4a (1972) ("For many years Merriam-Webster dictionaries have formed a series in which the unabridged dictionary is the parent work and the Collegiate Dictionary the largest abridgment. From each successive revision of the unabridged work new abridged books have sprung. ... The definitions [herein] are for the most part based on the most recent available information contained in the parent work, Webster's Third New International Dictionary, with such modifications or adaptations as are required by the smaller scope of the Collegiate."); WEBSTER's NEw COLleGiate DictionaRY iv (6th ed., 1949) (providing the language quoted in the 1972 publication of Webster's Seventh New Collegiate Dictionary, citing the "parent work," however, as "Webster's New International Dictionary, Second Edition"); see also WeBSTER's COLlEgIATE DICTIONARY, FIFTH EDITION (1936) "'The publication in 1934 of Webster's New International Dictionary, Second Edition, another complete revision of the unabridged dictionary, inaugurated a new Merriam-Webster series to which this present work belongs.").

102. See infra Tbl. 5, App. B. The American Heritage family remains in second place, with thirty-five (13.1\%) of the citations to any source, even if one extends it to include two other Houghton Mifflin dictionaries-Webster's II New Riverside University Dictionary and its successor title Webster's II New College Dictionary.

The American Heritage college dictionaries, like the Merriam-Webster college dictionaries, share a common editorial core with the much larger American Heritage Dictionary. See AMERICAN Heritage COllege Dictionary vii (3d ed. 1997) (calling AMERICAN HERITAGE DiCTIONARY (3d ed.) "[t] he immediate predecessor of the College 
Oxford University Press's family of dictionaries, which includes both the Oxford English Dictionary and the Shorter Oxford English Dictionary, comes in third with eighteen citations $(6.7 \%$ of all citations). Random House's family of dictionaries, the last identifiable family among the general purpose sources, takes fourth place with eleven citations $(4.1 \%$ of all citations).

Third, citations to specialized sources are considerably more spread out among different titles than citations to general purpose sources. For example, thirty-three of the forty-four specialized titles (74.4\%) are cited once and only once during the period of the study, and only three of them $(6.7 \%)$ are cited more than five times. By contrast, sixteen of the twenty-six general purpose titles $(61.5 \%)$ are cited more than once, and eight of them $(30.8 \%)$ are cited more than five times.

We also observed an interesting phenomenon not easily captured in any of the data tables. Specifically, in six different cases during the period of the study, all of them precedential, the Federal Circuit both used a dictionary to define a word from a disputed claim and then used a dictionary to define a word from the dictionary definition it had just quoted. ${ }^{103}$ Four of these six cases were issued in just the last two and one-half years. Interestingly, the second-order dictionary is not always the same as, or even the same type as, the first-order dictionary. Perhaps the most vivid instance of the phenomenon is the Novartis case, where the court forged a five-step chain of dictionary definitions of words appearing in other dictionary definitions: "hydrosol" (the claim term), to "sol," to "solution," to "medicinal," to "medicine," to "preparation." 104 The first four words were defined using two different general purpose dictionaries, and

Dictionary," and asserting that the College Dictionary "displays the[] same virtues and assets [as its parent] in a more compact form"); AMERICAN HERITAGE DICTIONARY, SECOND COLLEGE EDITION 6 (1985) (describing itself as "the first complete revision of the American Heritage Dictionary").

103. See Novartis Pharms. Corp. v. Eon Labs Mfg., Inc., 363 F.3d 1306, 1308-10, 70 U.S.P.Q.2d (BNA) 1438, 1440-41 (Fed. Cir. 2004) (tracing a long series of dictionary definitions of words in other dictionary definitions); Int'l Rectifier Corp. v. IXYS Corp., 361 F.3d 1363, 1372-74, 70 U.S.P.Q.2d (BNA) 1209, 1215-17 (Fed. Cir. 2004) (defining "annular," then "ring," then "band"; and defining "adjoining," then "adjacent"); Union Carbide Chems. \& Plastics Tech. Corp. v. Shell Oil Co., 308 F.3d $1167,1177,64$ U.S.P.Q.2d (BNA) 1545, $1551-52$ (Fed. Cir. 2002) (defining "characterizable," then "characterize"); Beckson Marine, Inc. v. NFM, Inc., 292 F.3d 718, 723-24, 63 U.S.P.Q.2d (BNA) 1031, 1033-34 (Fed. Cir. 2002) (defining "groove," then "channel"); Moore U.S.A., Inc. v. Standard Register Co., 229 F.3d 1091, 1114, 56 U.S.P.Q.2d (BNA) 1225, 1241 (Fed. Cir. 2000) (defining "along," then "by"); Great N. Corp. v. Henry Molded Prods., Inc., 94 F.3d 1569, 1574, 39 U.S.P.Q.2d (BNA) 1997, 2001 (Fed. Cir. 1996) (defining "flexural," then "flexure").

104. Novartis, 363 F.3d at 1308-09, 70 U.S.P.Q.2d (BNA) at $1440-41$. 
the last word was defined using three different specialized medical dictionaries. ${ }^{105}$

Who on the Federal Circuit has cited dictionaries when authoring claim construction opinions for the court? Table 7, contained in Appendix B, provides comprehensive data on this question. The Federal Circuit has twelve judges in regular active service and a number of senior judges. During the period studied here, from April 1995 to June 2004, sixteen judges were in regular active service on the Federal Circuit for at least some months; Table 7 notes the different periods of service for each of these sixteen judges. Every one of the judges authored at least one majority opinion for the court in which the court used at least one dictionary to help construe a disputed claim term. ${ }^{106}$ Six of the sixteen judges $(37.5 \%)$ each account for $10 \%$ or more of the 209 occasions on which the Federal Circuit has used one or more dictionaries to help construe a claim term. They are, in descending order of frequency of contribution, as follows:

- Judge Linn, with 27 of 209 (12.9\%)

- Judge Rader, with 26 of 209 (12.4\%)

- Judge Clevenger, with 24 of $209(11.5 \%)$

- Judge Lourie, with 23 of 209 (11.0\%)

- Judge Dyk, with 22 of $209(10.5 \%)$

- Judge Gajarsa, with 21 of $209(10.0 \%)$

Together, they account for $68.4 \%$ of the entries in the dataset. And of the six, three-Judges Dyk, Gajarsa, and Linn-joined the court after both Markman and Vitronics had already been decided.

It also appears from our data that, during the period of the study, the Federal Circuit judges who had patent law or technical backgrounds before joining the court cited a greater proportion of

105. Id., 70 U.S.P.Q.2d (BNA) at 1440-41. The dissenting judge in Novartis, with some justification, calls the majority's reasoning a "chase through the dictionary." Id. at 1315 n.7, 70 U.S.P.Q.2d (BNA) at 1444 n.1 (Clevenger, J., dissenting). Indeed, one could well call it a chase through five dictionaries.

106. Another indication of the pervasiveness of dictionary use is that, from August 1,2003 to June 30,2004 , all twelve judges in active service on the court joined at least one panel opinion in which the court used one or more dictionaries to help construe a disputed claim term. See Goldenberg v. Cytogen, Inc., 373 F.3d 1158, 1165-66, 71 U.S.P.Q.2d (BNA) 1255, 1260-61 (Fed. Cir. 2004) (Schall, Gajarsa, \& Prost, JJ.); Housey Pharms., Inc. v. AstraZeneca UK Ltd., 366 F.3d 1348, 1353, 70 U.S.P.Q.2d (BNA) 1641, 1645 (Fed. Cir. 2004)) (Mayer \& Clevenger, IJ.); Globetrotter Software, Inc. v. Elan Computer Group, Inc., 362 F.3d 1367, 70 U.S.P.Q.2d (BNA) 1161 (Fed. Cir. 2004) (Linn, Dyk, \& Archer, JJ.); Int'l Rectifier, 361 F.3d at 1363, 70 U.S.P.Q.2d (BNA) at 1209 (Newman, Linn, \& Prost, JJ.); Bancorp Servs., L.L.C. v. Hartford Life Ins. Co., 359 F.3d 1367, 69 U.S.P.Q.2d (BNA) 1996 (Fed. Cir. 2004) (Rader, Bryson, \& Prost, JJ.); Microsoft Corp. v. Multi-Tech Sys., Inc., 357 F.3d 134069 U.S.P.Q.2d (BNA) 1815 (Fed. Cir. 2004) (Lourie \& Bryson, JJ.); Abbott Labs. v. Syntron Bioresearch, Inc., 334 F.3d 1343, 67 U.S.P.Q.2d (BNA) 1337 (Fed. Cir. 2003) (Mayer, Michel, \& Dyk, IJ.). 
specialized reference sources than did the judges who did not have such backgrounds. The data are in Table 8. Using information from the judges' biographies, ${ }^{107}$ we separated all the judges who were in active service on the court from April 1995 to June 2004 into two groups: the judges who had a patent law or technical background, ${ }^{108}$ and the judges who did not. ${ }^{109}$ Using the opinion authorship data in Appendix C, we also counted the number of occasions a given judge cited one or more general purpose sources to help define a claim term, and the number of occasions a given judge cited one or more specialized sources to do so. When a given judge cited one or more general sources and one or more specialized sources to help define the same term, we counted the event in both columns of our table. ${ }^{110}$ As Table 8 shows, the judges with a patent law or technical background cited specialized sources $36.1 \%$ of the time, whereas the judges without a patent law or technical background did so $21.7 \%$ of the time. The difference in citation rate to specialized sources is statistically significant using the conventional test for whether two variables are independent. ${ }^{11}$

TABLE 8

Number of citations to one or more general or specialized references, grouped by Federal Circuit judge background

\begin{tabular}{|l|c|c|}
\cline { 2 - 3 } \multicolumn{1}{c|}{} & $\begin{array}{c}\text { GENERAL } \\
\text { SOURCES }\end{array}$ & $\begin{array}{c}\text { SPECIALIZED } \\
\text { SOURCES }\end{array}$ \\
\hline JUDGES WITH PATENT LAW OR & $\begin{array}{c}63.9 \% \\
(53 / 83)\end{array}$ & $\begin{array}{r}36.1 \% \\
(30 / 83)\end{array}$ \\
\hline TECHNICAL BACKGROUND & $78.3 \%$ & $21.7 \%$ \\
JUDGES WITHOUT PATENT & $(101 / 129)$ & $(28 / 129)$ \\
\hline LAW OR TECHNICAL & \multicolumn{2}{|c}{} \\
BACKGROUND &
\end{tabular}

107. See U.S. COURT FOR THE Federal Gircuit Court of APPEAls, JUdiclal BIOGRAPHIES (reporting biographical information for active and senior judges), at http://www.fedcir.gov/judgbios.html (last revised Jan. 25, 2005) (on file with the American University Law Review).

108. Six judges have a patent law or technical background: Judges Gajarsa, Linn, Lourie, Newman, Nies, and Rich.

109. Ten judges do not have a patent law or technical background: Judges Archer, Bryson, Clevenger, Dyk, Mayer, Michel, Plager, Prost, Rader, and Schall.

110. There were ten such instances in the full dataset.

111. Specifically, the likelihood that this different rate is due to chance alone, as measured by the $\chi 2$ statistic, is 0.02 . 
In sum, the data from our detailed review of individual cases show that (a) the Federal Circuit uses dictionaries to construe words in claims more often with each passing year; (b) it most often identifies only one reference source per word; (c) it uses general purpose English language dictionaries more than twice as often as specialized sources, consistent with the "neutral sources"-based Telegenix rationale (and not the "specialized knowledge"-based Markman rationale) for dictionary use; (d) it uses Webster's Third most of all; (e) just over a third of the judges who have served on the Federal Circuit since the Markman decision account for more than two thirds of the occasions where the court has used dictionaries to construe disputed claim terms; and (f) judges with a patent law or technical background cite specialized reference sources at a greater rate than those without such a background. Both general purpose and specialized dictionaries and similar reference sources have become central to the Federal Circuit's claim construction jurisprudence.

\section{BIAS THROUGH THE BACK DOOR? DICTIONARY SELECTION AT COURT}

The Federal Circuit's cases firmly establish both that one should begin the claim construction process by presuming that a term has its ordinary meaning to a person of skill in the art, and that one can use a dictionary or similar objective reference source to help establish this ordinary meaning. The Federal Circuit's actual dictionary citation behavior over the last nine years just as firmly shows that, when the court uses a dictionary to establish the ordinary meaning of a disputed claim term, it most often does so by reference to a single general purpose English language dictionary. And although a full theoretical critique of judicial use of dictionaries to help establish ordinary meaning is beyond the scope of this Article, ${ }^{112}$ common experience suggests both that one interprets a new document by using one's prior understandings of word meanings, and that it is entirely wholesome to augment one's untutored understanding of a word's meaning by consulting a dictionary, professionally prepared at great effort, to remind oneself of the full range of ordinary meanings that a given word possesses. Indeed, the Supreme Court highlighted this very use of dictionaries in the context of legal disputes over a century ago. ${ }^{113}$

112. See supra note 24 (distinguishing the question whether the Federal Circuit should use dictionaries from the question of how the Federal Circuit can best use dictionaries, having chosen to do so).

113. See Nix v. Hedden, 149 U.S. 304, 306-07 (1893) (categorizing tomatoes as 
It is not enough, however, simply to note that dictionaries can be helpful. There is an important middle step between the act of writing a definition for a word (back in the publishing house's lexicography shop) and the act of quoting a definition (in a judicial opinion or a lawyer's brief) -namely, choosing which dictionary (or dictionaries) to use from among the available candidates. The court often uses Webster's Third New International Dictionary, but not always. The Federal Circuit's increasing reliance on dictionaries thus raises an important question: how does the court select the dictionary it uses in any given case? ${ }^{114}$

The selection question is a critical one because the court now justifies its use of dictionaries primarily by reference to the neutrality with which professional lexicographers write dictionary definitions. ${ }^{115}$ This neutrality-based justification for favoring dictionaries rings quite hollow, of course, if the way the court picks the dictionary it uses in a given case is not itself neutral. Put another way, to achieve the full measure of neutrality, and thus predictability, that the Federal Circuit has set as its claim construction goal, one should be able to state in advance some rule or principle that guides dictionary selection without regard to the merits of the case in which the dictionary will be used. Sadly, the cases suggest a large share of judicial caprice in dictionary selection. One cannot, moreover, dismiss the arbitrariness in dictionary selection as inconsequential. We consider, in turn, both the lack of formal constraints on court choice of dictionaries in claim construction, and the demonstrable difference in case outcome that the choice among dictionaries can make.

\section{A. Dictionary Choice Unchained-The Dark Side of Telegenix}

A court confronting a claim construction dispute today can, after the dispute is well under way and the parties' general positions on the merits are clear, effectively pick whatever dictionary it prefers to help

\footnotetext{
"vegetables," rather than as "fruit," for purposes of a tariff schedule). "Of that [ordinary] meaning the [C]ourt is bound to take judicial notice, as it does in regard to all words in our own tongue; and upon such a question dictionaries are admitted, not as evidence, but only as aids to the memory and understanding of the [C] ourt." Id.

114. As one commentator has observed, "[ $\mathrm{t}]$ he first step toward claim interpretation using a dictionary should be selecting an appropriate dictionary, a step that was not addressed by the Telegenix court and which is neither straightforward nor inconsequential." Hattenbach, supra note 60, at 187.

115. See Tex. Digital Sys., Inc. v. Telegenix, Inc., 308 F.3d 1193, 1203, 64 U.S.P.Q.2d (BNA) 1812, 1818 (Fed. Cir. 2002) (praising dictionaries because they are "not influenced by expert testimony or events subsequent to the fixing of the intrinsic record by the grant of the patent, not colored by the motives of the parties, and not inspired by litigation").
} 
construe the words in the claim. The only apparent constraint is a temporal one: the reference source should have been publicly available as of the filing date of the application that matured into the patent in suit. ${ }^{116}$ Importantly, a court is not bound by the parties' evidentiary submissions in the litigation. The Federal Circuit took pains to emphasize the point in the Telegenix case:

As resources and references to inform and aid courts and judges in the understanding of technology and terminology, it is entirely proper for both trial and appellate judges to consult these materials [i.e., dictionaries, encyclopedias, and treatises] at any stage of a litigation, regardless of whether they have been offered by a party in evidence or not. ${ }^{117}$

To the extent one views a publicly available reference work's content as an adjudicative fact, Telegenix is consistent with the Federal Rules of Evidence governing judicial notice of such facts, ${ }^{118}$ which empower courts to take notice on their own initiative ${ }^{119}$ both at trial and on

116. See Kopykake Enters., Inc. v. Lucks Co., 264 F.3d 1377, 1383, 60 U.S.P.Q.2d (BNA) 1124, 1127 (Fed. Cir. 2001) ("[W] hen a claim term understood to have a narrow meaning when the application is filed later acquires a broader definition, the literal scope of the term is limited to what it was understood to mean at the time of filing."); Schering Corp. v. Amgen Inc., 222 F.3d 1347, 1353, 55 U.S.P.Q.2d (BNA) 1650,1654 (Fed. Cir. 2000) ("Rather, the [claim] term 'IFN- $\alpha$ ' in the patent has a specialized meaning limited to the particular leukocyte interferon that Dr. Weissman supported in his original application. In sum, this court must determine what the term meant at the time the patentee filed the " 901 application."). The principle that a claim term forever has the same meaning it had on the date the application was filed is a longstanding one. See Universal Oil Prods. v. Globe Oil \& Ref. Co., 137 F.2d 3, 6, 58 U.S.P.Q. (BNA) 504, 504 (7th Cir. 1943) ("Moreover, the meaning which the inventor gives to his words can not be made to depend upon subsequent events, but should appear when the application is filed.").

The Federal Circuit has, in some recent cases, sown needless confusion on this point. The cases just cited establish that, as a doctrinal matter, the key date for fixing the meaning of a claim term is the application's filing date. Even if this were not already a matter of settled doctrine, the filing date is the only date that makes any sense in view of patent law requirements regarding a given written disclosure's ability to properly support a given set of claims. See infra Part III.B. It is thus quite strange that in the Telegenix case the court speaks of reference sources that are "publicly available at the time the patent is issued." Telegenix, 308 F.3d at 1203,64 U.S.P.Q.2d (BNA) at 1818 (emphasis added). After Telegenix, the Federal Circuit has twice stated that its "decisions have not always been consistent as to whether the pertinent date is the filing date of the application or the issue date of the patent." Inverness Med. Switz. GmbH v. Princeton Biomeditech Corp., 309 F.3d 1365, 1370 n.1, 64 U.S.P.Q.2d (BNA) 1926, 1930 n.1 (Fed. Cir. 2002); Inverness Med. Switz. GmbH v. Warner Lambert Co., 309 F.3d 1373, 1378 n.2, 64 U.S.P.Q.2d (BNA) 1933, 1936 n.2 (Fed. Cir. 2002). There is no cause for the court to be coy: the filing date is the one that matters, and the Telegenix court erred on this point.

117. Telegenix, 308 F.3d at 1203, 64 U.S.P.Q.2d (BNA) at 1819 (emphasis added).

118. See Fed. R. Evid. 201(a)-(b). See generally Christopher B. MUELler \& LAIRD C. KIRKPATRICK, EVIDENCE $\$$ 2.7, at 80-81 \& n.9 (3d ed. 2003) (discussing judicial notice of such "verifiable facts" as "language or word usage").

119. Fed. R. Evid. 201 (c) ("A court may take judicial notice, whether requested or not."). 
appeal. ${ }^{120}$ Historically, judicial notice has been the ground on which the Supreme Court based its own use of dictionaries. ${ }^{121}$ To the extent one views dictionary content as a legislative rather than an adjudicative fact, ${ }^{122}$ the Federal Rules of Evidence do not regulate the situation at all. ${ }^{123}$

The lack of formal constraints does not, of course, mandate that a judge simply indulge her personal preference when choosing a dictionary to help define a word in a patent claim. The Federal Circuit, however, has not stated any rules or principles for how a judge should choose a dictionary in this context-not how to decide between using a general purpose or a specialized reference source, or how to decide precisely which (or how many) reference source(s) to use from among several candidates, or how to distill some core ordinary meaning from multiple definitions in multiple sources. ${ }^{124}$ Judges, both trial and appellate, are thus left with little more to guide them than personal preference-preference for one dictionary over

120. Fed. R. Evid. 201(f) ("Judicial notice may be taken at any stage of the proceeding."); MUELLER \& KIRKPATRICK, supra note $118, \S 2.10$, at 90 . The Federal Circuit has taken judicial notice of facts in reliable documents in a number of cases. See Genentech, Inc. v. Chiron Corp., 112 F.3d 495, 497 n.1, 42 U.S.P.Q.2d (BNA) 1608, 1609 n.1 (Fed. Cir. 1997); Hoganas AB v. Dresser Indus., 9 F.3d 948, 954 n.27, 28 U.S.P.Q.2d (BNA) 1936, 1941 n.27 (Fed. Cir. 1993); Standard Havens Prods., Inc. v. Gencor Indus., Inc., 897 F.2d 511, 514 n.3, 13 U.S.P.Q.2d (BNA) 2029, 2031 n.3 (Fed. Cir. 1990).

121. See Lexicon Fortress, supra note 8 , at $246-48$.

122. On the distinction between legislative and adjudicative facts, see BLACK's LAW DICTIONARY 610-11 (7th ed. 1999) and MUELLER \& KIRKPATRICK, supra note 118, $\$ \S 2.2-2.3$, at $65-72$.

123. MUELLER \& KIRKPATRICK, supra note 118, § 2.3, at 66 ("The Federal Rules of Evidence do not regulate the process of noticing legislative facts.").

124. The Federal Circuit, tacitly acknowledging its failure thus far to provide any guidance on these critical questions, requests, in its en banc order in Phillips, see supra notes 17-18 and accompanying text, additional briefing on, among others, the following two questions: "What use should be made of general as opposed to technical dictionaries? How does the concept of ordinary meaning apply if there are multiple dictionary definitions of the same term?" Phillips v. AWH Corp., 376 F.3d 1382, 1383, 71 U.S.P.Q.2d (BNA) 1765, 1766 (Fed. Cir. 2004) (Question \#2).

In fairness to the Federal Circuit, the court is hardly alone in failing to give meaningful guidance on dictionary selection. The Supreme Court, too, has failed to state any rules or principles governing how courts should choose dictionaries when construing statutes and the like, and scholars have criticized the Court accordingly. See Lexicon Fortress, supra note 8, at 264-76 (providing extended critique of the "confusion" resulting from the fact that, "[a]lthough the Court has relied on dictionaries for nearly 170 years, there are few articulated principles to provide guidance to the Court's use of dictionaries"); Rickie Sonpal, Note, Old Dictionaries and New Textualists, 71 FORDHAM L. REV. 2177, 2197-2201 (2003) (reviewing critiques of the Supreme Court's unpredictable dictionary selection practices); Looking It Up, supra note 8, at 1447-48 ("Yet there has been no apparent pattern to (or discussion of) the Justices' choices of [dictionary] volume or vintage.... If the Court is serious about its quest for ordinary meaning, it should not continue to employ dictionaries in such a chaotic fashion."). 
another, or preference for one internal, unstated guideline over another.

For example, one judge might opt to rely on the dictionary cited by the party he finds more persuasive on other grounds, converting dictionaries from useful tools for reaching sound conclusions into post hoc rationalizations. Another judge might opt consistently for unabridged over collegiate dictionaries. Yet another judge might opt to stick with the dictionary she has at hand in her chambers, or in the courthouse library, when it is time to make a decision. Indeed, given the lack of guidance from the Federal Circuit, one cannot be surprised at the following exchange, involving an experienced federal trial judge, at a three-day patent law conference in September 2003:

Returning to the notion that claim construction should begin with the dictionary meaning of the disputed term, a conference participant suggested that different dictionaries may provide inconsistent definitions, leaving a judge with the need to decide which dictionary to rely upon. [U.S. District] Judge [T.S.] Ellis [E.D. Va.] shot back, "I use the dictionary in my library." 23

Such an approach to dictionary choice is neither neutral nor predictable. Indeed, to the degree that cases are assigned to judges at random, the "it's in my library" method amounts to random dictionary selection. This state of affairs is, from a systemic perspective, highly undesirable.

Dictionary selection by judicial caprice is not merely the stuff of anecdote. Our detailed review of dictionary-citing cases from April 1995 to June 2004 reveals two troubling phenomena that underscore the chaotic way in which the Federal Circuit itself appears to choose dictionaries for claim construction. First, we identified four cases in which the Federal Circuit used a dictionary different from the dictionary it reported the trial court had used in the same case. ${ }^{126}$ In

125. Judge Lourie Defends CAFC Reversals, PTO Chief Rogan Promises Patent Quality, 66 Pat. Trademark \& COPYRICHT J. 580, 581 (Sept. 26, 2003), available at http://pubs.bna.com/ip/BNA/PTC.NSF. It is not clear from the report whether Judge Ellis was referring to a library in his chambers or instead to a general library at the courthouse where he works.

126. Linear Tech. Corp. v. Impala Linear Corp., 379 F.3d 1311, 1324, 72 U.S.P.Q.2d (BNA) 1065, 1073 (Fed. Cir. 2004) (Linn, J.) (shifting from Webster's Ninth New Collegiate Dictionary to Webster's Third New International Dictionary to help define a claim term); Int'l Rectifier Corp. v. IXYS Corp., 361 F.3d 1363, 1370-74, 70 U.S.P.Q.2d (BNA) 1209, 1214-17 (Fed. Cir. 2004) (Linn, J.) (shifting from Webster's Ninth New Collegiate Dictionary to Webster's Third New International Dictionary to help define three separate claim terms); Inverness Med. Switz. GmbH v. Warner Lambert Co., 309 F.3d 1373, 1378, 64 U.S.P.Q.2d (BNA) 1933, 1936 (Fed. Cir. 2002) (Dyk, J.) (shifting from Merriam-Webster's New Collegiate Dictionary to both Webster's Third New International Dictionary and Shorter Oxford English Dictionary to help define two separate claim terms); Johnstown Am. Corp. v. Trinity Indus., Inc., Nos. 97-1070, 97-1071, 
none of these four cases does the Federal Circuit explain, in any way, why it chose a dictionary different from the one the trial court used. The dictionary switches in these cases are made all the more puzzling by the fact that the Federal Circuit has, in other cases, used all the dictionaries it rebuffs from the trial judges in these four cases. Why the inter-court switch? A Federal Circuit preference for unabridged over college dictionaries (which could explain three of the four cases)? The chosen book's ready availability in a chambers or court library? The personal preference of an opinion's authoring judge? Some other reason? The court does not say.

Second, we identified four cases (separate from those just discussed) in which the Federal Circuit uses different dictionaries to define two different words from the very same disputed phrase in the claim. ${ }^{127}$ In the most recent of the cases, for example, the court construes the claim phrase "opening for connecting" by, among other things, looking up the definition of "opening" in the Oxford English Dictionary and the definition of "connect" in Webster's Third New Intermational Dictionary. ${ }^{128}$ In none of these four cases does the Federal Circuit explain, in any way, why the dictionary used to define one word in the phrase is inadequate or inappropriate when defining the other word in the very same phrase. Why the mid-phrase switch? Did the parties themselves cite the dictionaries in this pattern? If so, what about this citation pattern was persuasive? Was one dictionary more comprehensive on the desired term than the other? Some other reason? Again, the court does not say.

It thus appears to the outside observer that the Federal Circuit effectively chooses dictionaries at random. To be sure, both the sweeping mandate of Telegenix (licensing any dictionary at any time) and the freewheeling approach to dictionary selection that its own cases reveal maximize the Federal Circuit's freedom to obtain the objective reference(s) that it finds most helpful-whatever that

1997 WL 291956, at *1-3 (Fed. Cir. 1997) (Archer, J.) (shifting from American Heritage Dictionary to Dictionary of Architecture $\mathcal{E}$ Construction to help define a claim term).

127. TI Group Auto. Sys. (N. Am.), Inc. v. VDO N. Am., L.L.C., 375 F.3d 1126, 1138, 71 U.S.P.Q.2d (BNA) 1328, 1337 (Fed. Cir. 2004) (Linn, J.) (using two different general purpose dictionaries for two different words); Housey Pharms., Inc. v. AstraZeneca UK Ltd., 366 F.3d 1348, 1353, 70 U.S.P.Q.2d (BNA) 1641, 1645 (Fed. Cir. 2004) (Clevenger, J.) (using two different specialized dictionaries for two different words); Anchor Wall Sys. v. Rockwood Retaining Walls, Inc., 340 F.3d 1298, 1311, 67 U.S.P.Q.2d (BNA) 1865, 1869-70 (Fed. Cir. 2003) (Gajarsa, J.) (using two different general purpose dictionaries for two different words); Karlin Tech., Inc. v. Surgical Dynamics, Inc., 177 F.3d 968, 971, 50 U.S.P.Q.2d (BNA) 1465, 1468 (Fed. Cir. 1999) (using a general purpose dictionary for one word and a specialized dictionary for another).

128. TI Group, 375 F.3d at 1138, 71 U.S.P.Q.2d (BNA) at 1337. 
means-at a given moment. When a court chooses a dictionary according to this approach, it knows, of course, its own dictionary predilections, the bottom-line positions of each party offering any other dictionary, and the final conclusion it favors based on the other materials in the case. ${ }^{129}$ This approach, which replaces judicial caprice for party bias, is thus quite at odds with the neutrality that Telegenix praises as the reason to prefer dictionaries over resources such as expert testimony. ${ }^{130}$ The price of the courts' freedom is the costly uncertainty the court imposes on all other actors in the patent system-patentees, potential licensees, accused infringers, the Patent Office-who are simply left to guess, for good or ill, what dictionary a trial court may choose when litigation arises and what dictionary (perhaps a different one) the Federal Circuit may choose on appeal. Nor is the guessing game mere sport. The dictionary that a court chooses to help define a claim term can have a demonstrable effect on the case's outcome.

\section{B. The Difference a Different Dictionary Can Make}

One might posit, in response to the apparent caprice in dictionary selection just discussed, that there is no harm in such caprice because dictionaries do not differ enough in content for the choice among them to materially affect a case's outcome. There is doubtless some common sense appeal to this notion. After all, professional lexicographers, whether writing a general purpose English language dictionary or a specialized dictionary, strive to define the words in a common lexicon, e.g., standard American English, or standard medical terminology. All dictionary writers are under enormous

129. In a thoughtful discussion of the Federal Circuit's "ordinary meaning" cases, Barney posits that judicial selection of a dictionary is preferable to litigant selection of a dictionary. See Barney, supra note 42, at 126. Specifically, Barney argues, "unlike [with] other sources of extrinsic evidence, a judge can pull a dictionary from his or her own shelf and find a definition of a disputed term free from any influence by the litigants." Id. (emphasis in original). First, we disagree that a judge who has heard the parties' arguments on claim construction is "free from any influence by the litigants." Second, even if Barney is right about the absence of litigant influence, a "let the judge choose" strategy provides no guidance to parties who are attempting in good faith to avoid litigation in the first place, either by licensing the patent or designing around the claimed invention. Surely our goal should be to develop a claim construction methodology that helps opposing interests accurately assess their respective likelihoods of success were litigation to occur and thus dispense with the need actually to litigate at all.

130. See Texas Digital Sys., Inc. v. Telegenix, Inc., 308 F.3d 1193, 64 U.S.P.Q.2d (BNA) 1812 (Fed. Cir. 2002) (dictionaries are helpful because they are "not influenced by expert testimony or events subsequent to the fixing of the intrinsic record by the grant of the patent, not colored by the motives of the parties, and not inspired by litigation"). 
pressure to be concise, ${ }^{131}$ and concision leaves less room for differing creative expressions. All reputable dictionary writers use extensive evidence of common usage ${ }^{132}$ and, in the case of specialized terms, copious input from accomplished experts in the relevant field. ${ }^{193}$ Finally, competing lexicographers have, since the birth of the English language dictionary, aggressively monitored (and sometimes avidly borrowed from) one another's published definitions. ${ }^{134}$ The hunch

131. See LANDAU, supra note 2, at 173 ("Almost every defining characteristic common to dictionaries can be traced to the need to conserve space.").

132. The "chief sources of definitions" for modern dictionaries are "the citation file and the electronic corpus." Id. at 189. According to Landau, a "citation file is a selection of potential lexical units in the context of actual usage, drawn from a variety of written sources and often some spoken sources, chiefly because the context illuminates an aspect of meaning." Id. at 190 (emphasis in original). And a "corpus... is a collection of different texts or of recorded speech, nowadays stored electronically on a computer and indexed so that any particular word can be found quickly in the context in which it has been used." Id.; see also id. at 192-93 (contrasting electronic corpora from citation files). Landau provides both exemplar citation slips and sample corpus printouts. See id. at 196-99 (citation slips in Figs. 813); id. at 194 (corpus printout in Fig. 7); see also BÉJOINT, supra note 79, at 97-99 (discussing usage-based evidence for definitions). All lawyers are, of course, familiar with the corpora known as Westlaw and LexisNexis.

133. See LANDAU, supra note 2, at 168 ("Although usage in scientific terminology is given much weight when it is available, in general imposed definitions are determined by a consensus of experts."); $i d$. at 191 (noting that general purpose dictionaries "rely on specialists to define the large percentage of scientific and technical terms."); $i d$. at 213 ("Most scientific and technical terms must be defined by specialists on the basis of their judgments about preferred scientific usage."). Consulting experts (or, at least, claiming to) is as old as Edward Phillips' The New World of English Words (1658), in which the author vouched "for the accuracy of his definitions by naming specialist sources of information, for example 'Dr Sparks' for 'physicks', 'Mr Molins' for 'botanicks', and 'Dr Wybard' for geometry." Michael Rand Hoare \& Vivian Salmon, The Vocabulary of Science in the OED, in LEXICOGRAPHY AND THE OED: PIONEERS IN THE UNTRODDEN FOREST 156, 156, 171 (Lynda Mugglestone ed., 2000).

134. As Landau succinctly states, "[m]odern lexicographers look very carefully at each other's work." Id. at 43. The practice is dictated, in part, by the profit motive: "Few modern commercial publishers have an instinct for scholarship so pure that they will spend millions of dollars to redo what other, better scholars have done before them." Id. at 44. As a result, when a new dictionary project begins, one scrutinizes existing sources. According to Landau,

Dictionary makers acquire every significant new dictionary as soon as it is published. One's direct competitors' works are examined with due care to see what new terms they have included-or failed to include. ... Another dictionary's definition must be considered along with other citations for the word being defined. ... [C] ommercial dictionaries are now loath to admit having relied on a competitor. For marketing reasons, every dictionary is represented as being unaffected by every other. Nothing could be further from the truth.

Id. at 214. Even so, not all dictionaries are equal: "the Merriam-Webster dictionaries in America and the Oxford dictionaries in the UK are less influenced by other dictionaries than other dictionaries are by them." Id. at 402. For an engaging discussion of detailed examples of verbatim definition borrowing, in dictionaries both modern and antique, see Robert Burchfield, The Genealogy of Dictionaries, in UNLOCKING THE ENGLISH LANGUAGE 147 (1989).

Borrowing a competitor's handiwork verbatim is as old as English lexicography. 
that different dictionaries often converge in their definitions is thus consistent with actual lexicography practice.

At the same time, important differences among competing dictionaries exist alongside convergence in some definitions. First, different dictionaries approach crafting the body of a definition differently. Consider the flagship dictionaries of the two groups that the Federal Circuit cites most often, Webster's Third New International Dictionary and American Heritage Dictionary. A definition in Webster's Third, for example, is consciously designed to be "a single coherent and clearly expressed phrase that need[s] no punctuation except where commas [are] essential to separate words or groups of words in a series." 185 In addition, the definitions in Webster's Third carry only minimal status and usage labeling. ${ }^{196} \mathrm{~A}$ definition in American Heritage, by contrast, is not confined to the single-statement defining

Robert Cawdrey's A Table Alphabeticall (1604), "most often accepted as the first [English monolingual] dictionary," copied liberally from two Latin-English works. LANDAU, supra note 2, at 46, 48. Cawdrey's work was in turn copied liberally by " $[t]$ he next English dictionary," John Bullokar's An English Expositor (1616). Id. at 48. In short, "[ $t$ ] he earliest English lexicographers by and large copied the definitions of their predecessors." Id. at 190.

135. MORTON, supra note 3 , at 87 . This defining style, pioneered by Philip Babcock Gove, the Editor-in-Chief of Webster's Third, was "Gove's most distinctive innovation" in the work. Id. The style produced some clunkers and thus had its critics. Id. For example, Webster's Third broadly defines the noun "door" as follows:

1 a: a movable piece of firm material or a structure supported usu. along one side and swinging on pivots or hinges, sliding along a groove, rolling up and down, revolving as one of four leaves, or folding like an accordion by means of which an opening may be closed or kept open for passage into or out of a building, room, or other covered enclosure or a car, airplane, elevator, or other vehicle-see kalamein door, panel door

WEBSTER'S THIRD NEW INTERNATIONAL DICTIONARY 674 (2002).

136. MORTON, supra note 3 , at 135 ("The most striking of Gove's policies on usage was his decision to cut back on the use of the slang label, eliminate the label colloquial entirely, and put greater reliance on illustrative quotations and usage notes to indicate the status of words that were on the borderline of standard English."). As Morton recounts in comprehensive detail, Gove's choice to minimize status and usage labeling in Webster's Third was savaged by many reviewers and hailed by others in the two years following the book's first publication. Id. at 153-214. See also Robert Burchfield, Words and Meanings in the Twentieth Century, in UNLOCKING THE ENGLISH LANGUAGE 61, 76 (1989) ("The publication of Webster's Third New International Dictionary in 1961 was greeted with immense pleasure by most academic reviewers and with implacable hostility by nearly every journalist who reviewed it. University teachers loved its inclusiveness and its up-to-dateness. Journalists spoke of 'sabotage at Springfield': they judged it to be a work of deplorable linguistic permissiveness.").

So spirited were the so-called "prescriptivist/descriptivist" debates attending the publication of Webster's Third, the controversy yielded an anthology of detractors' and supporters' reviews. See Dictionaries and THAT DictionaRY: A CASEbOOK ON THE AIMS OF LEXICOGRAPHERS AND THE TARGETS OF REVIEWERS 50-250 (James Sledd \& Wilma R. Ebbitt eds., 1962). Gove later defended his policy on status and usage labels. See also Philip B. Gove, Usage in the Dictionary, in THE Role Of THE DictionarY 51 (Philip B. Gove ed., 1967). 
style of Webster's Third, ${ }^{137}$ and American Heritage provides both copious status labeling and usage advice from a 200-member "usage panel."138 These differences are, in fact, rooted in the great controversy that erupted with the publication of Webster's Third in 1961: both the American Heritage Dictionary, first published in 1969, and the "usage panel" device it inaugurated, were direct responses to what its publisher viewed as the radical descriptivism of Webster's Third. ${ }^{139}$

Second, when defining a word with multiple senses, different dictionaries order the several senses differently. There are two conventional approaches to ordering these senses: chronologically (or historically), ranging from earliest to most recent sense; and logically, ranging from more to less important or frequent sense. A given dictionary usually states its approach to ordering senses in its "front matter," which most users rarely, if ever, consult. ${ }^{140}$ Funk \& Wagnalls pioneered ordering senses by frequency of usage in its Standard Dictionary (1893) and New Standard Dictionary (1913), ${ }^{141}$ and logical ordering is now the more common way to organize senses. ${ }^{142}$ Both Merriam-Webster and Oxford University dictionaries order senses chronologically. ${ }^{143}$ Both American Heritage and Random

137. For example, American Heritage broadly defines the noun "door" as "[a] movable structure used to close off an entrance, typically consisting of a panel that swings on hinges or that slides or rotates." AMERICAN HERITAGE DICTIONARY 536 (4th ed. 2000).

138. See American Heritage Dictionary viii (4th ed. 2000) ("The Usage Notes are based on periodic surveys of the Usage Panel, a group of some 200 distinguished writers, scholars, scientists, and other respected users and students of the English language."); $i d$. at xiii-xv (listing members of the usage panel); see also LANDAU, supra note 2, at 93 ("The one extraordinary feature of the American Heritage dictionaries apart from their [graphic and color illustration] design has been the introduction of a usage panel of putative 'good writers' whose judgments about disputed usages are supposed to provide guidance for the rest of the benighted English-speaking world.").

139. See LANDAU, supra note 2, at 93-94 (discussing the early history of the American Heritage Dictionary); MORTON, supra note 3, at 223-25, 228-32 (same).

140. See LANDAU, supra note 2, at 148 ("The trend in recent years has been to cut back on front matter because it is widely believed among lexicographers that no one reads it.").

141. See id. at 86.

142. See BÉJOINT, supra note 79 , at 50.

143. See WEBSTER's THIRD NEW INTERNATIONAL Dictionary 17a, I 12.5 (2002) ("The order of senses is historical: the one known to have been first used in English is entered first."); 1 SHORTER OXFORD ENGlish DICTIONARY xvii-xviii, II 4.10 (5th ed. 2002) (explaining chronological ordering of senses); l OXFORD ENGLISH DICTIONARY xxix (2d ed. 1989) ("[T]hat sense is placed first which was actually the earliest in the language: the others follow in the order in which they appear to have arisen."); WEBSTER's NINTH NEW COLLEGIATE DICTIONARY 19 (1985) ("The order of senses within an entry is historical: the sense known to have been first used in English is entered first.... When a numbered sense is further subdivided into lettered subsenses ... their order is likewise historical: subsense la is earlier than $1 \mathrm{~b}, 1 \mathrm{~b}$ is earlier than 1c, and so forth."). For a lucid and detailed account of the way in which James A.H. Murray and his assistants crafted definitions for the first edition of the 
House dictionaries, by contrast, order senses from more to less central usage. ${ }^{144}$

These important differences among different dictionaries can, in turn, generate different claim construction analyses. First, when a court uses only one dictionary in aid of its claim construction, the dictionary's content may differ fromsothers in a way that hits hard at the patentee's core disagreement with the accused infringer. Second, these content-based effects may be compounded by the fact that, when a court uses multiple dictionaries to derive a unified ordinary meaning for a disputed word, it can select from among varied approaches to forging one definition from many sources. A brief review of three Federal Circuit cases from the last year amply demonstrates the substantive difference that selecting different dictionaries can make.

\section{The usage note case}

In International Rectifier Corp. v. IXYS Corp., ${ }^{145}$ the Federal Circuit confronted a claim construction dispute involving a patented semiconductor chip structure. The claimed structure included both a "wafer of semiconductor material having a relatively lightly doped major body portion" and "a further region of opposite conductivity type adjoining [the] lightly doped major body portion." ${ }^{146}$ The accused infringer's liability for infringement of the claims using the word "adjoining" turned entirely on whether or not "adjoining" requires that the major body portion and the further region touch each other. ${ }^{147}$

The district court, quoting defining language from Webster's Ninth New Collegiate Dictionary, concluded that "two objects need not be in physical contact to be "adjoining." "148 IXYS, the accused infringer,

Oxford English Dictionary, see Penny Silva, Time and Meaning: Sense and Definition in the $O E D$, in LEXICOGRAPHY AND THE OED: PIONEERS IN THE UNTRODDEN FOREST 77 (Lynda Muggleston ed., 2000).

144. See American Heritage Dictionary xxxiv (4th ed. 2000) ("Entries containing more than one sense are arranged for the convenience of contemporary dictionary users with the central and often the most commonly sought meaning first. Senses and subsenses are grouped to show their relationships with each other."); AMERICAN Heritage College Dictionary xxv (3d ed. 1997) (same); Random House DICTIONARY OF THE ENGLISH LANGUAGE xxxii (2d ed. 1987) ("In each part of speech group, the most frequently encountered meanings generally come before less common ones."); RANDOM HOUSE WEBSTER'S UNABRIDGED DICTIONARY xviii (2d ed. 1997) (same).

145. 361 F.3d 1363, 70 U.S.P.Q.2d (BNA) 1209 (Fed. Cir. 2004).

146. Id. at 1367,70 U.S.P.Q.2d (BNA) at 1212 (quoting claim 19 of U.S. Patent No. 4,959,699 (issued Sept. 25, 1990)).

147. Id. at 1375, 70 U.S.P.Q.2d (BNA) at 1218.

148. Id., 70 U.S.P.Q.2d (BNA) at 1218. 
conceded that it could not avoid infringement of the claims under the district court's construction of "adjoining." ${ }^{49}$

What does this dictionary actually say? The Ninth New Collegiate defines "adjoin" as "to lie next to or in contact with" and "to be close to or in contact with one another," and defines "adjoining" as "touching or bounding at a point or line." 150 The definition of "adjoining" also directs the reader to the definition of "adjacent," which it labels a synonym. ${ }^{151}$ The Ninth New Collegiate defines "adjacent" as "not distant," "having a common endpoint or border," and "immediately preceding or following." 152 All these definitions suggest that one can, consistent with ordinary usage, use both adjoining and adjacent to describe two items that are close to each other but not touching. Most importantly for our discussion here, the definition of "adjacent" in the Ninth New Collegiate further includes a usage note contrasting adjoining and adjacent, a note to which the district court made no apparent reference:

ADJACENT, ADJOINING, CONTIGUOUS, JUXTAPOSED mean being in close proximity. ADJACENT may or may not imply contact but always implies absence of anything of the same kind in between; ADJOINING definitely implies meeting and touching at some point or line; CONTIGUOUS implies having contact on all or most of one side; JUXTAPOSED means placed side by side esp. so as to permit comparison and contrast. ${ }^{153}$

On appeal, the Federal Circuit reversed the district court's construction of "adjoining," holding that this word in the claims requires physical contact between the major body portion and the further region. ${ }^{154}$ It also held that, as a matter of law, IXYS could not have infringed the claims containing the "adjoining" requirement. ${ }^{155}$ First, and without explaining why, the Federal Circuit switched from the Ninth New Collegiate to the 1966 printing of Webster's Third New International Dictionary. ${ }^{156}$ Second, after quoting the definitions of "adjoining" and "adjacent" from Webster's Third, the court focused on the Webster's Third version of the usage note (appended to the definition of "adjacent") that contrasts these two synonyms.

149. Id., 70 U.S.P.Q.2d (BNA) at 1218.

150. WEBSTER'S NINTH NEW COLLEGIATE DicTIONARY 56 (1985).

151. Id.

152. Id.

153. Id.

154. Int'l Rectifier Corp. v. IXYS Corp., 361 F.3d 1363, 1375, 70 U.S.P.Q.2d (BNA) 1209, 1218 (Fed. Cir. 2004).

155. Id., 70 U.S.P.Q.2d (BNA) at 1218.

156. Id. at 1374, 70 U.S.P.Q.2d (BNA) at 1217.

157. Id., 70 U.S.P.Q.2d (BNA) at 1217. 
The usage note in Webster's Third is quite a bit longer than the corresponding note in the Ninth New Collegiate. It states, in relevant part, as follows:

ADJACENT is sometimes merely a synonym for near or close to. Applied to things of the same type, it indicates either side-by-side proximity or lack of anything of the same nature intervening. ADJOINING is quite similar to ADJACENT in meaning and suggestion but may more strongly indicate existence of common bounding lines or lines or points of junction. ${ }^{158}$

The Federal Circuit, after quoting this usage note, concludes that the district court erred by ignoring its teaching. According to the Federal Circuit,

$[T]$ he district court was not free to disregard this usage note.... [T] he district court's adoption of a definition [for "adjoining"] attributed to "adjacent," a synonym of the claim term, disregards entirely the distinction between the two terms set forth in the usage note. Had the inventor meant "adjacent," he could have used that word. ${ }^{159}$

The court betrays no hint of irony at faulting the district court for "disregarding" a usage note in a dictionary that the district court never consulted.

Putting the unexplained dictionary switch to one side, it seems sensible at first blush to conclude that, having decided to consult a dictionary, one must take all that one finds there-both the bitter and the sweet, as it were. And the Ninth New Collegiate, like Webster's Third, includes a usage note for "adjacent" that tilts decidedly in favor of the Federal Circuit's construction of "adjoining." Then one wonders, do other dictionaries draw precisely the same distinctions between "adjoining" and "adjacent" that the Merriam-Webster sources do? If not, perhaps more weight has been put on these usage notes than they can bear.

As it turns out, the American Heritage dictionaries-which as a group take second place among the Federal Circuit's most commonly cited general purpose dictionaries-distinguish "adjoining" from

158. WEBSTER'S THIRD NEW INTERNATIONAL DICTIONARY 26 (1966) (illustrative quotations omitted). The 2002 printing of Webster's Third contains the very same definitions and usage note. See WEBSTER'S THIRD NEW INTERNATIONAL DICTIONARY 2627 (2002). In addition, the Addenda Section of the 2002 printing, id. at 55a-144a, which contains new words and new senses of words that have entered the lexicon since 1961, does not provide any additional information for "adjacent" or "adjoining." See id. at 55a. We suspect that many who use post-1961 printings of Webster's Third do not know about the existence of, much less the importance of consulting, the Addenda Section. The Federal Circuit appears never to have cited it.

159. Int'l Rectifier, 361 F.3d at 1374, 70 U.S.P.Q.2d (BNA) at 1217. 
"adjacent" far less tidily than do the Merriam-Webster sources. The entire definitions of "adjoining" and "adjacent" from the three American Heritage sources are as follows:

\begin{tabular}{|l|l|l|}
\cline { 2 - 3 } \multicolumn{1}{c|}{} & \multicolumn{1}{c|}{ "ADJOINING" } & \multicolumn{1}{c|}{ "ADJACENT" } \\
\hline $\begin{array}{l}\text { American Heritage } \\
\text { Dictionary 21 (4th } \\
\text { ed. 2000) }\end{array}$ & $\begin{array}{l}\text { Neighboring; } \\
\text { contiguous. }\end{array}$ & $\begin{array}{l}\text { 1. Close to; lying near; } \\
\text { adjacent cities. 2. Next to; } \\
\text { adjoining: adjacent garden } \\
\text { plots. }\end{array}$ \\
\hline $\begin{array}{l}\text { American Heritage } \\
\begin{array}{l}\text { College Dictionary } \\
16 \text { (3d ed. 1997) }\end{array}\end{array}$ & $\begin{array}{l}\text { Neighboring; } \\
\text { contiguous. }\end{array}$ & $\begin{array}{l}\text { 1. Close to; lying near; } \\
\text { adjacent cities. 2. Next to; } \\
\text { adjoining: adjacent garden } \\
\text { plots. }\end{array}$ \\
\hline $\begin{array}{l}\text { American Heritage } \\
\text { Dictionary 79 (2d } \\
\text { college ed. 1985) }\end{array}$ & $\begin{array}{l}\text { Neighboring; } \\
\text { contiguous; } \\
\text { next to. }\end{array}$ & $\begin{array}{l}\text { 1. Close to; lying near. } \\
\text { 2. Next to; adjoining. }\end{array}$ \\
\hline
\end{tabular}

None of these three dictionaries has any usage note for either word. Nor do any of them even point from the word "adjoining" to the word "adjacent." The definition of "adjacent" merely uses the word "adjoining."

It thus appears that, had the Federal Circuit switched to an American Heritage dictionary rather than switching to Webster's Third, it might well have affirmed the district court's construction of "adjoining" and the concomitant infringement liability judgment. Instead, it reversed the claim construction and the liability judgment. Dictionary selection seems to have made the difference between liability and no liability.

\section{The high frequency and wood board cases: Making one from many}

Two recent cases expose an important methodological choice that arises when one tries to use definitions from multiple dictionaries to create a single statement of a word's ordinary meaning. One option is to take as the word's ordinary meaning only the select material that is common to all the definitions; another option is take as the word's ordinary meaning the totality of the material from all the definitions. ${ }^{160}$ The first approach, which extracts material common to all the definitions, has the virtue of identifying the meaning of the target word that is most widely and well-established in the relevant language community. And it is the settled nature of ordinary

160. We owe this point to John Duffy. 
meaning that makes ordinary meaning-and the use of a dictionary to identify it-attractive as a default rule for claim construction. ${ }^{16}$ The second approach, which embraces all material found in any definition, has the virtue of identifying the broadest possible range of ordinary meaning for the target word. And it is the promise of a comprehensive reminder which augments one's untutored understanding that makes consulting a dictionary a helpful exercise. ${ }^{162}$ Both methods, then, are consonant with some of the policy bases for relying on dictionaries. Choosing between the methods, one must note, also interacts with one's choice of dictionaries, given that dictionaries vary in content. Which method should a court use when creating one definition of a disputed claim term from many dictionaries? Interestingly, each of the two Federal Circuit cases to which we now turn uses a different one of these two methodologies.

In Intellectual Property Development, Inc. v. UA-Columbia Cablebvision of Westchester, Inc., ${ }^{163}$ the Federal Circuit construed the phrase "high frequency carrier" in a patent claim covering a wired broadcasting system. $^{164}$ The district court, relying on both the McGraw-Hill

161. Thus, for example, the Federal Circuit recently rejected the efforts of both a patentee and an accused infringer to rely on reference sources that reflected changing, rather than settled, meanings of the claim term under dispute. In the case, captioned ACTV, Inc. v. Walt Disney Co., 346 F.3d 1082, 68 U.S.P.Q.2d (BNA) 1516 (Fed. Cir. 2003), the parties disputed the scope of the claim term "uniform resource locator." Each party urged the court to rely on one of two dueling reference documents, called Requests for Comments or RFCs, from the internet standard setting body known as the World Wide Web Consortium. Id. at 1088-89, 68 U.S.P.Q.2d (BNA) at 1520-21. The Federal Circuit rejected both reference documents on the ground that they did not reflect a settled meaning for the target term:

The purpose of the RFCs is ... to collect commentary and to select language to facilitate a common understanding, or to select a standard, from a variety of competing technologies and vocabularies and from a variety of potentially competing interests.... This purpose is in sharp contrast to the role of dictionaries and treatises, which aim not to select or give meaning to a word or phrase, but to report the meaning already established and commonly understood by those skilled in the art.... Because the RFCs were not designed to reflect common usage, but rather to assign language to facilitate further conversation, and because of the seeming contradictions between RFC 1738 and RFC 1808, we conclude that both documents are extrinsic evidence... [and] we decline to rely on them in our claim construction analysis.

Id., 68 U.S.P.Q.2d (BNA) at 1522.

The reader interested in learning more about the role of RFCs in developing internet standards should consult Scott Bradner, The Internet Engineering Task Force, in OPEN SOURCES: VOICES FROM THE OPEN SOURCE REVOLUTION 47, 50 (Chris DeBona et al. eds., 1999).

162. See supra note 113 and accompanying text.

163. 336 F.3d 1308, 67 U.S.P.Q.2d (BNA) 1385 (Fed. Cir. 2003).

164. Id. at 1310-12, 67 U.S.P.Q.2d (BNA) at 1388. 
Dictionary of Scientific and Technical Terms and Webster's Seventh New Collegiate Dictionary, construed "high frequency" to mean between three and thirty MHz. ${ }^{165}$ The Federal Circuit, for its part, affirmed this construction of "high frequency," relying on the same dictionaries as the district court. ${ }^{166}$

In reaching this conclusion, the Federal Circuit rejected the patentee's contention that it was improper to define "high frequency" so narrowly given the existence of dictionaries that define the phrase more broadly. Specifically, the patentee presented broader definitions from both the Oxford English Dictionary and the Dictionary of Electronics. ${ }^{167}$ The Federal Circuit resolved the apparent problem with the broader definitions by pointing out, with the help of extended quotations from them, that they also included the narrower equation of "high frequency" with " 3 to 30 megahertz." 168 In other words, without expressly stating it, the court used the first of the two methodologies described above: take as the ordinary meaning only that which is common to multiple dictionary definitions. The narrower construction of "high frequency" precluded infringement liability. ${ }^{169}$ Less than a year later the court shifted ground to the other methodology.

In Nystrom v. TREX Co., ${ }^{170}$ the Federal Circuit construed the noun "board" in a patent claim covering a flooring board with a top surface designed to slope gradually off to either side of the center. ${ }^{171}$ The patentee contended that the word "board" covered both wood boards and synthetic boards; the accused infringer, who made synthetic boards that otherwise fell within the scope of the patent claims, contended that "board" covered only wood boards. ${ }^{172}$ The district court, agreeing with the accused infringer, construed "board" to mean "a piece of elongated construction material made from wood cut from a $\log . " 173$ The Federal Circuit reversed this construction, defining "board" as "an elongated, flat piece of wood or other rigid material."

165. Id. at $1314-15,67$ U.S.P.Q.2d (BNA) at 1389.

166. Id. at 1315-16, 67 U.S.P.Q.2d (BNA) at 1389-90.

167. Id. at 1315, 67 U.S.P.Q.2d (BNA) at 1390.

168. Id. at 1316 n.7, 67 U.S.P.Q.2d (BNA) at 1390 (quoting from Oxford English Dictionary and Dictionary of Electronics).

169. Id. at 1317, 67 U.S.P.Q.2d (BNA) at 1391.

170. 374 F.3d 1105, 71 U.S.P.Q.2d (BNA) 1241 (Fed. Cir. 2004).

171. Id. at $1107-08,71$ U.S.P.Q.2d (BNA) at 1243.

172. Id. at $1110-11,71$ U.S.P.Q.2d (BNA) at 1245.

173. Id. at 1110,71 U.S.P.Q.2d (BNA) at 1245 .

174. Id. at 1113,71 U.S.P.Q.2d (BNA) at 1247. 
Just as in UA-Columbia, the Federal Circuit confronted multiple, differing dictionary definitions of the critical term. Specifically, Webster's Third New International Dictionary and American Heritage Dictionary define "board" differently, and the difference is precisely the 'wood only v. wood and synthetic' distinction. Webster's Third defines "board," in relevant part, as "a piece of sawed lumber of little thickness but considerable surface area usu. being rectangular and of a length greatly exceeding its width." 75 American Heritage, by contrast, defines "board," in relevant part, as both "[a] long flat slab of sawed lumber; a plank" and "[a] flat piece of wood or similarly rigid material adapted for a special use." ${ }^{\prime 76}$ The court quoted both definitions, noting that " $[\mathrm{w}]$ hile some dictionaries define 'board' solely in reference to its material composition, not all dictionaries are so constrained." 177

Had the Nystrom panel followed the same methodology as the UAColumbia panel, the court would have distilled from these disparate definitions that which is common to both and thus defined "board" to mean "a slab of sawed lumber." 178 Under that construction, it would have affirmed the district court's judgment of no liability. Instead, the court adopted the opposite methodology-combining material mentioned in any definition, rather than extracting material mentioned in all definitions. According to the Federal Circuit, the differing Webster's Third and American Heritage definitions "show that the ordinary meaning of the word 'board' encompasses both a piece of cut wood or sawn timber and a similarly-shaped item made of rigid material." 7 The court did not cite, much less discuss, the UAColumbia case.

In the foregoing cases, the court's dictionary selections and methods for using dictionaries directly affected the liability outcome. It is, of course, possible that in most other instances in which the Federal Circuit used one or more dictionaries to help construe a claim term, the court would have reached the very same outcome no matter what dictionary it used. But it is not likely. Dictionary choice matters. And thus the need remains for a principled, predictable

175. WebSTER's ThIRd NeW INTERNATIONAL DictionaRy 243 (2002) (sense 3a). The Addenda Section defines additional senses for the noun "board," id. at 65 a, but none of them is relevant here. It is interesting to note that, had the Federal Circuit used one dictionary alone (which is the more common technique), and that dictionary had been Webster's Third (which it cites most often, see Apps. B \& C), the case could well have come out the opposite way.

176. AMERICAN HERITAGE DICTIONARY 203 (4th ed. 2000).

177. Nystrom, 374 F.3d at 1111-12, 71 U.S.P.Q.2d (BNA) at 1246.

178. Id., 71 U.S.P.Q.2d (BNA) at 1246.

179. Id., 71 U.S.P.Q.2d (BNA) at 1246. 
dictionary selection method that shares the neutrality of dictionary writing, i.e., that helps one get dictionary content that is free from the biasing influence of the parties' position-dictated views or the judge's purely personal preferences. The method we propose achieves this predictability and neutrality by mandating that dictionary selections be made before the parties to a dispute can know which reference sources best favor the outcomes they desireindeed, before the patent, at the heart of a later dispute, even exists.

\section{Moving Dictionary Choice to the Patent Office}

The presumption of ordinary meaning has great merit. A person of ordinary skill in the art to which a patent pertains is knowledgeable about both the art itself and the ways that people in the art talk and write about their work. As a result, when a person of ordinary skill in the art reads a patent, she looks at the words that the patentee has used in light of the ordinary meaning that those words have to people skilled in the art. Patentees surely know this about their readers. Only nonce words-words that are coined for a single occasion ${ }^{180}$ often lack an ordinary meaning outside the context of the patent. Patentees know this, too. It is thus quite sensible to assume that, unless there is good evidence to the contrary, the patentee has chosen the words in the written description and the claims of the patent according to their ordinary meaning. The Federal Circuit's heavy presumption of ordinary meaning builds this insight into the claim construction process. ${ }^{181}$

180. WebSTER's THIRD NEW INTERNATIONAL DiCTIONARY 1535 (2002) (defining adjective "nonce" as "occurring, used, or made only once or for a special occasion"). The highfalutin term is hapax legomenon. Id. at 1030. Nonce words can have an ordinary meaning upon being coined if they are constructed using other well known words. For example, no one who lived through or knew about the Nixon resignation had any trouble understanding on first reading the popular press terms "travelgate" (the dustup over firings at the White House Travel Office early in President Clinton's first term), "nannygate" (the sinking of President Clinton's first nominee to be Attorney General, Zoë Baird, over her having employed two illegal immigrants to work as nannies) or "zippergate" (a colorful term for the Lewinsky scandal) - all of which are derived analogically from the Watergate break-in scandal that destroyed the Nixon presidency. See generally Dieter Kastovsky, Words and Word-Formation: Morphology in OED, in LEXICOGRAPHY AND THE OED: PIONEERS IN THE UNTRODDEN FOREST 110, 113 (Lynda Mugglestone ed., 2000) (discussing the ways in which "a nonce-formation can usually be satisfactorily interpreted by the listener when he or she hears it for the first time").

James A.H. Murray, the editor of the first edition of the Oxford English Dictionary, coined the phrase "nonce word" to describe items that appeared in only one source. See 1 OXFORD ENGLISH DICTIONARY xxvii (2d ed. 1989) ("Words apparently employed only for the nonce, are, when inserted in the Dictionary, marked nonce-wd."); see also 10 OXFORD ENGLISH DictionARY 487 (2d ed. 1989) (definition 1, sense 4, of "nonce").

181. See supra notes $38-44$ and accompanying text. 
Consulting dictionaries and similar usage-based sources to determine ordinary meaning also has great merit. Of course, even our most comprehensive dictionaries cannot map all the linguistic terrain. As Robert Burchfield, editor of the four-volume Supplement to the Oxford English Dictionary from 1957 to $1986,{ }^{182}$ put it, there is a "never-ending raggedness, stretching away into the darkness, of our language at the perimeter of what we can manage to put in our largest dictionaries." ${ }^{183}$ All the same, it is better to aid subjective memory with objective resources than to rely on subjective memory alone. The Federal Circuit's turn to dictionaries as helpful reminders about the full range of a word's ordinary meaning to a person of ordinary skill follows, in this respect, a well-worn judicial path. ${ }^{184}$ The empirical evidence discussed above, which shows that all current members of the Federal Circuit have relied on dictionaries in claim construction to at least a degree, ${ }^{185}$ strongly suggests that the court will not stop using dictionaries altogether as a claim construction tool. ${ }^{186}$ The court's dictionary selections in individual cases, however, remain troublingly chaotic.

The Federal Circuit, having chosen to presume that patentees select words for a claim according to their ordinary meaning, is right to seek out this meaning in "unbiased reflections of common understanding" that are "not colored by the motives of the parties, and not inspired by litigation." ${ }^{187}$ The court cannot reach this goal, however, without identifying some predictable basis upon which to deploy objective reference sources that were publicly available to the patentee and others in the art at the time the patent application was filed.

182. See Robert Burchfield, Linguistic Milestones, in UNLOCKING THE ENGLISH LANGUAGE 3, 3 (1989).

183. Id. at 19 (quoting a letter he wrote to Anthony Burgess, novelist and literary critic, in 1986). One of the Federal Circuit's predecessor courts made a similar point in discussing the freedom the law gives every patentee to coin new words in a patent:

Often the invention is novel and words do not exist to describe it. The dictionary does not always keep abreast of the inventor. It cannot. Things are not made for the sake of words, but words for things. To overcome this lag, patent law allows the inventor to be his own lexicographer.

Autogiro Co. v. United States, 384 F.2d 391, 397, 155 U.S.P.Q. (BNA) 697, 502 (Ct. Cl. 1967).

184. See supra note 113 and accompanying text.

185. See infra Tbl. 7, App. B.

186. We concede that, as a formal matter, the en banc order in the Phillips case puts a "no more dictionaries" option in play. See supra notes 17-18 and accompanying text. As a practical matter, however, we do not think it is likely that the court will choose the "no more dictionaries" option.

187. Tex. Digital Sys., Inc. v. Telegenix, Inc., 308 F.3d 1193, 1203, 64 US.P.Q.2d (BNA) 1812, 1818 (Fed. Cir. 2002). 
One might be tempted to conclude that the Federal Circuit can bring about this predictability entirely on its own. We conclude otherwise. To appreciate why, consider the following thought experiment: Imagine that the court declares that, so far as it is concerned, (a) the definitive general purpose English language dictionary is Webster's Third New International Dictionary, (b) it will consult one and only one general purpose English language dictionary, Webster's Third, when determining a contested claim's ordinary meaning, and (c) it will consult the printing of Webster's Third that most closely precedes the disputed patent's filing date. This framework, which has the virtue of maximizing predictability (at least in the short run), is far too brittle to survive. Its largest defect, apart from grossly violating existing patentees' settled expectations about the acceptability of numerous dictionaries, ${ }^{188}$ is the failure to take any account of the court's preference, about thirty percent of the time, for specialized reference sources. ${ }^{189}$

Imagine, then, that the court modifies the simple framework above to include specialized reference sources. The court cannot limit itself to a single specialized source because it reviews cases from numerous technological domains. As the court tries to answer questions that necessarily arise when it uses multiple sources, predictability quickly begins to collapse. When should one use a specialized source rather than a general purpose source? Should one use a single specialized source, or multiple sources? Which source(s) $?^{190}$ If one uses multiple sources, how does one forge a single meaning from what they say as a group? Most of these questions likely cannot be answered in a way that applies robustly across a large number of patents, even within a single field of art. Moreover, if the court somehow managed to

188. This is not a small problem. The Supreme Court has cautioned the Federal Circuit against violating patentees' settled expectations with jarring retroactive changes to the rules of the patent game. See Festo Corp. v. Shoketsu Kinzoku Kogyo Kabushiki Co., 535 U.S. 722, 739 (2002) ("[C]ourts must be cautious before adopting changes [to patent law] that disrupt the settled expectations of the inventing community.").

189. See supra Tbl. 8.

190. This question is probably the toughest for the court to answer. First, a single case is simply not a good vehicle for issuing what amount to prospective regulations about acceptable reference books. Second, even if it wanted to try to identify mandated reference books case by case, the court does not have the institutional resources to determine, for any given field at a given time, which specific reference books were the highest quality for claim construction purposes. For example, which specialized reference is best for pharmaceutical inventions made in the late 1980s? For computer software inventions made in the early 1990s? For semiconductor chip inventions made in 2000? Nor does the problem stand still. As time rolls forward, the court would have to keep identifying the best reference sources over and over again. 
provide answers that had some staying power, the prior decision to permit use of only one general purpose source (Webster's Third in our hypothetical) would doubtless come under relentless pressure from parties who stood to gain, in their respective cases, from the use of a different general purpose dictionary (e.g., American Heritage Dictionary). The task of drafting what amount to complex dictionary citation regulations, in the guise of deciding cases, would thus begin anew with the general purpose sources. ${ }^{191}$

This brief thought experiment should be enough to show that the Federal Circuit, if forced to undertake the task alone, is ill suited to make dictionary selection substantially more predictable. All the court alone can do, at least at this time, is mandate a closed list of the reference sources it will consult. Happily, the Federal Circuit is not alone.

The Patent Office, another key player in our patent system, ${ }^{192}$ is well suited to deploy its power over patent examination procedure to render dictionary selection far more predictable. And it can do so without relying on closed source lists. ${ }^{193}$ Specifically, as we describe in detail below, the Patent Office can and should require all patent applicants to state their dictionary preferences, both general purpose and specialized, on the face of their patent applications at the time of

191. At least one commentator has concluded that choosing dictionaries for use in statutory interpretation cases is better resolved by legislative than by judicial action. See Nicholas Quinn Rosenkranz, Federal Rules of Statutory Interpretation, 115 HARV. L. Rev. 2085, 2143-48 (2002). According to Rosenkranz, "Congress could provide: 'When Courts have recourse to a dictionary in interpreting any federal statute enacted after this one, it shall be the Oxford English Dictionary, second edition, and no other." "Others, it must be said, have criticized his proposals. See Larry Alexander \& Saikrishna Prakash, Mother May I? Imposing Mandatory Prospective Rules of Statutory Interpretation, 20 CONST. COMMENT. 97 (2003).

192. See generally Rai, supra note 26.

193. Professor Wagner, in a recent article that wisely urges greater attention to the ex ante effects of patent law doctrines, suggests that "a rule assigning the default meaning of claim terms according to a standard dictionary would be beneficial," at least "in the sense that [the rule] would induce patentees to be clear about the meanings of the words they choose for the claims." R. Polk Wagner, Reconsidering Estoppel: Patent Administration and the Failure of Festo, 151 U. PA. L. REv. 159, 244 \& n.312 (2002) (footnote omitted). He notes, in connection with recommending "a standard dictionary," that "the PTO could promulgate an 'official' list of standard reference sources, related to technological field where appropriate." Id. at 244 n.311. Under this approach, "[c]laim terms would ... be presumed to take the meaning assigned in the standard source, unless the patentee clearly designated a different meaning." Id. The interim half of the proposal we describe below resembles Professor Wagner's approach, although we do not think it is advisable for the Patent Office to devote resources to developing a consensus about which reference sources merit inclusion on an official agency list. See infra Part III.C.3. We propose, instead, that each patent examiner have the flexibility to specify, in the context of each separate patent application, which reference sources will be consulted absent objection from the applicant. See infra Part III.C.2. 
filing. ${ }^{194}$ In any subsequent claim construction process, whether for licensing, design-around, or litigation purposes, parties would look to the reference sources that the patentee himself selected. The courts, including the Federal Circuit, would limit themselves to the same patentee-selected resources when adjudicating a claim construction dispute; they would do so in accordance with the general principle that a patentee is bound in subsequent litigation by the statements she made in the intrinsic patent record. ${ }^{195}$ The Patent Office would thus, in effect, add another facet to the longstanding practice of allowing patentees to provide controlling express definitions for any claim terms in the body of the patent. ${ }^{196}$ Put another way, patentees, who are already empowered to be their own lexicographers, i.e., dictionary writers, would also be their own dictionary choosers. Such an approach provides courts with a way to use dictionaries that is both highly predictable and tailored to each patent. This rule's properly cognizable cost to the applicant is small, and the benefit to those who must construe the patent in the future is large.

Before elaborating on our proposed change to the Patent Office's procedural rules, we address two questions that might arise about the

194. See infra Part III.C.

195. See, e.g., Springs Window Fashions LP v. Novo Indus., L.P., 323 F.3d 989, 995, 65 U.S.P.Q.2d (BNA) 1826, 1830 (Fed. Cir. 2003) ("The public notice function of a patent and its prosecution history requires that a patentee be held to what he declares during the prosecution of his patent."); Vectra Fitness, Inc. v. TNWK Corp., 162 F.3d 1379, 1384, 49 U.S.P.Q.2d (BNA) 1144, 1148 (Fed. Cir. 1998) ("The public is entitled to rely upon the public record of a patent in determining the scope of the patent's claims."); Key Pharms. v. Hercon Labs. Corp., 161 F.3d 709, 716-17, 48 U.S.P.Q.2d (BNA) 1911, 1917 (Fed. Cir. 1998) ("Competitors are entitled to rely on the public record of the patent, and if the meaning of the patent is plain, the public record is conclusive."); Vitronics Corp. v. Conceptronic, Inc., 90 F.3d 1576, 1583, 39 U.S.P.Q.2d (BNA) 1573, 1577 (Fed. Cir. 1996) ("[C]ompetitors are entitled to review the public record, apply the established rules of claim construction, ascertain the scope of the patentee's claimed invention and, thus, design around the claimed invention."); see also Riverwood Int'l Corp. v. R.A. Jones \& Co., 324 F.3d 1346, 1354, 66 U.S.P.Q.2d (BNA) 1331, 1337 (Fed. Cir. 2003) ("This court and its predecessor have held that a statement by an applicant during prosecution identifying certain matter not the work of the inventor as 'prior art' is an admission that the matter is prior art.").

196. See 3M Innovative Props. Co. v. Avery Dennison Corp., 350 F.3d 1365, 1371, 1374, 69 U.S.P.Q.2d (BNA) 1050, 105455, 1057 (Fed. Cir. 2003); Markman v. Westview Instruments, Inc., 52 F.3d 967, 980, 34 U.S.P.Q.2d (BNA) 1321, 1330 (Fed. Gir. 1995) (en banc), affd, 517 U.S. 370 (1996); Fromson v. Advance Offset Plate, Inc., 720 F.2d 1565, 1569, 219 U.S.P.Q. (BNA) 1137, 1140-41 (Fed. Cir. 1983); In re Vogel, 422 F.2d 438, 441, 164 U.S.P.Q. 619, 622 (C.C.P.A. 1970); Autogiro Co. v. United States, 384 F.2d 391, 397, 155 U.S.P.Q. 697, 702 (Ct. Cl. 1967). The leading claim drafting guide recommends the following technique: "When one wishes to impart a special meaning to a word or phrase appearing in the claims, one should define that word or phrase in the specification; for example, "As used in this description and in the appended claims, the word "_" means "_." " ROBERT C. Faber, Landis on Mechanics of Patent Claim Drafting $\$ 19$, at III-15 (4th ed. 2001). 
Patent Office playing any role in dictionary selection: whether compelling dictionary selection falls within the agency's power over examination procedure; and whether appropriate dictionary selections can be made at the time the patent application is filed. The short answer to both questions is, "Yes."

\section{A. Patent Office Power Over Dictionary Choice}

The Patent Act grants the Patent Commissioner "broad powers" over PTO practice. ${ }^{197}$ It is equally clear, however, that "Congress has not vested the Commissioner with any general substantive rulemaking power."198 Specifically, the Patent Act gives the Commissioner the power to "establish regulations, not inconsistent with law, which ... shall govern the conduct of proceedings in the Office," ${ }^{199}$ i.e., to make procedural rules that bind patent applicants. When the Patent Office promulgates a rule under this grant of power, it must use notice-and-comment rulemaking in accordance with the Administrative Procedure Act. ${ }^{200}$ The Federal Circuit, in turn, gives such a procedural rule controlling weight unless it is

197. Gerritsen v. Shirai, 979 F.2d 1524, 1528, 24 U.S.P.Q.2d (BNA) 1912, 1915 (Fed. Cir. 1992); see also id. at 1527 n.3, 24 U.S.P.Q.2d (BNA) at 1915 n.3 ("Congress thus delegated plenary authority over PTO practice, including interference proceedings, to the Commissioner."); Stevens v. Tamai, 366 F.3d 1325, 1333, 70 U.S.P.Q.2d 1765, 1771 (Fed. Cir. 2004) (same).

198. Merck \& Co. v. Kessler, 80 F.3d 1543, 1550, 38 U.S.P.Q.2d (BNA) 1347, 1351 (Fed. Cir. 1996) (rejecting Patent Office's contention that its gap-filling interpretation of two complex patent term provisions was a substantive agency regulation entitled, if reasonable, to controlling deference under Chevron U.S.A., Inc. v. Natural Res. Def. Council, 467 U.S. 837, 842-45 (1984)); see also Animal Legal Defense Fund v. Quigg, 932 F.2d 920, 930, 18 U.S.P.Q.2d (BNA) 1677, 1686 (Fed. Cir. 1991) (concluding that Patent Office policy regarding the substantive reach of the Patent Act's "patentable subject matter" provision, 35 U.S.C. $\$ 101$ (1988), was merely an interpretive rule and thus not required to be established through "notice and comment" rulemaking).

199. 35 U.S.C. \$ 2(b) (2) (A) (2001). From 1952 to 1999 , this grant of power was set forth in 35 U.S.C. $\$ 6$. See Intellectual Property and Communications Omnibus Reform Act of 1999, 113 Stat. 1501A-521 to 603, $\$ 4712$ (pp. 572-73, amending 35 U.S.C. \$ 2). The Patent Office has had this power over examination procedure since 1870. See Act of July 8, 1870, ch. 230, $\$ 19,16$ Stat. 198, 200 (“[T] he Commissioner, subject to the approval of the Secretary of the Interior, may from time to time establish rules and regulations, not inconsistent with law, for the conduct of proceedings in the patent office.").

200. See 5 U.S.C. $\$ 553$ (2001) (establishing "notice and comment" rulemaking); 35 U.S.C. $\$ 2$ (b) (2) (B) (requiring that Patent Office procedural rules "shall be made in accordance with section 553 of title 5 , United States Code"). The current rules governing the conduct of Patent Office proceedings are codified in Title 37 of the Code of Federal Regulations. For a concise description of notice-and-comment rulemaking in federal agencies, see 1 RICHARD J. PIERCE, JR., ADMINISTRATIVE LAW TREATISE $\$ 7.3$ (4th ed. 2002). There is no question that the Patent Office is an "agency" for purposes of the Administrate Procedure Act. See Dickinson v. Zurko, 527 U.S. 150, 154 (1999). 
“"arbitrary, capricious, or manifestly contrary to the statute."”201 One might wonder, against this backdrop, whether the Patent Office has the power to require every patent applicant to state, on the face of her application, what publicly available general purpose and specialized dictionaries she wants the Office to use in the event it needs help from such sources to construe the scope of her proposed claims. In short, is such a dictionary rule procedural? If it is, the Patent Office has the power to promulgate it.

It is important, when analyzing the divide between procedural and substantive rules in the patent law context, to keep in mind the Patent Office's primary task-to assess the patentability of the inventions put before it by applicants. The Patent Act broadly provides that, when it receives a patent application, the Patent Office "shall cause an examination to be made of the application and the alleged new invention" to assess its patentability under the Act. ${ }^{202} \mathrm{~A}$ patent issues to the applicant, upon payment of the proper fees, ${ }^{203}$ "if on such examination it appears that the applicant is entitled to a patent under law." ${ }^{204}$ To assess a claim's compliance with each of the Patent Act's substantive patentability requirements-utility, ${ }^{205}$ novelty, ${ }^{206}$ nonobviousness, ${ }^{207}$ and an adequately supporting written disclosure ${ }^{208}$ - a patent examiner must establish the scope of the claim under review. ${ }^{209}$ The Patent Act alone, however, provides only

201. In re Sullivan, 362 F.3d 1324, 1328, 70 U.S.P.Q.2d (BNA) 1145, 1149 (Fed. Cir. 2004) (quoting Chevron U.S.A., Inc. v. Natural Res. Def. Council, 467 U.S. 837, 844 (1984)) (rejecting challenge to validity of Patent Office procedural rule); Tamai, 366 F.3d at 1333-34, 70 U.S.P.Q.2d (BNA) at 1771-72 (upholding reasonableness of Patent Office procedural rule).

202. 35 U.S.C. $\$ 131$. As the Federal Circuit has succinctly stated, "It is the PTO's duty to assure that the statutory requirements for patentability are met." In re Morris, 127 F.3d 1048, 1054, 44 U.S.P.Q.2d 1023, 1028 (Fed. Cir. 1997).

203. 35 U.S.C. $\$ 151$.

204. Id. \$ 131 .

205. Id. $\S 101$; see also MuLLLer, supra note 22, at 155-59 (discussing utility requirement).

206. 35 U.S.C. $\$ 102$; see also MUELLER, supra note 22, at 91, 93 (discussing novelty requirements).

207. 35 U.S.C. § 103; see also MUELLER, supra note 22, at 131-34 (discussing nonobviousness requirement).

208. 35 U.S.C. $\$ 112$, I 1; see also MUELLER, supra note 22, at 65-67 (discussing best mode, enablement, and written description requirements).

209. See 35 U.S.C. $\$ \$ 102,103,112$ (referring throughout to "the invention"); see also Rockwell Int'l Corp. v. United States, 147 F.3d 1358, 1362, 47 U.S.P.Q.2d (BNA) 1027, 1029 (Fed. Cir. 1998) ("The first step in any invalidity or infringement analysis is claim construction."); In re Wilson, 424 F.2d 1382, 1385, 165 U.S.P.Q. (BNA) 494, 496 (C.C.P.A. 1970) ("All words in a claim must be considered in judging the patentability of that claim against the prior art."). It is thus no surprise that the Manual of Patent Examining Procedure, the Patent Office's official "set of instructions to the examining corps," In re Kaghan, 387 F.2d 398, 401, 156 U.S.P.Q.2d (BNA) 130, 132 (C.C.P.A. 1967), includes a lengthy discussion of 
sparsely phrased general requirements for what an applicant must do to present a proper patent application. ${ }^{210}$ To flesh out the details of this minimalist statutory framework, the Patent Office has promulgated detailed regulations governing the manner in which an applicant must present her materials. ${ }^{211}$

Many of the Patent Office's regulations governing patent applications appear designed to facilitate an examiner's prompt and efficient comprehension of the scope of the applicant's proposed claims. For example, to implement the Patent Act's broadly framed requirement of a specification that describes the invention and ends with numbered claims, ${ }^{212}$ the Patent Office details both the materials the specification must contain ${ }^{213}$ and the order in which those materials must be arranged. ${ }^{214}$ Similarly, to implement the Patent Act's broadly framed provision about illustrative drawings, ${ }^{215}$ the Patent Office maintains highly detailed regulations governing the form and content of patent drawings. ${ }^{216}$ All these regulations, which no doubt have some incidental effect on the substance of applicants' resulting patent rights, are framed with the primary goal of structuring the patent examination process to facilitate accurate and efficient assessment of claim patentability. These rules are thus procedural, in that they are designed not to shape the primary behavior of inventors (e.g., inventors' decisions to invent new solutions to problems or, instead, use known solutions), but rather to

important claim construction principles. See U.S. PATENT \& TRADEMARK OFFICE, U.S. DeP'T OF Commerce, Manual Of Patent Examining Procedure $\$ \S 2111,2173.05$ (a) (8th ed. 2001, rev. ed. 2003) [hereinafter MPEP], available at http://www.uspto.gov/ web/offices/pac/mpep/index.html; see also Refac Int'l, Ltd. v. Lotus Dev. Corp., 81 F.3d 1576, 1584 n.2, 38 U.S.P.Q.2d (BNA) 1665, 1671 n.2 (Fed. Cir. 1996) ("The MPEP does not have the force and effect of law; however, it is entitled to judicial notice as the agency's official interpretation of statutes or regulations, provided that it is not in conflict with the statutes or regulations.").

210. 35 U.S.C. $\$ 111$ (a) (2) (requiring that an application contain "a specification as prescribed by" 35 U.S.C. $\$ 112$, "a drawing as prescribed by" 35 U.S.C. $\$ 113$, and "an oath by the applicant as prescribed by" 35 U.S.C. $\$ 115$ ). A special preliminary application, called a "provisional application," can be filed without including any separately numbered claim paragraphs. Id. $\S 111(\mathrm{~b})(2)$; see also MUELLER, supra note 22 , at 378 . The existence of this sort of preliminary patent does not alter the points discussed here.

211. See 37 C.F.R. $\$ \S 1.51-1.59$ (2004) (application); $\$ \$ 1.63-1.69$ (inventor's oath); $\S \S 1.71-1.79$ (specification); $\$ \S 1.81-1.85$ (drawings); $\$ \S 1.97-1.98$ (information disclosure statement); $\$ \$ 1.801-1.825$ (biotechnology invention disclosures).

212. 35 U.S.C. $\$ 112$, II $1,2$.

213. 37 C.F.R. $\$ \$ 1.71-1.75$.

214. $\$ 1.77(\mathrm{~b})$.

215. 35 U.S.C. $\$ 113$.

216. 37 C.F.R. $\$ \$ 1.83-1.84$. 
improve the accuracy and efficiency of inventors' engagement with government officials who assess their legal rights. ${ }^{217}$

Most interestingly, for our purposes, the Patent Office has already promulgated a regulation directly targeted at helping an examiner readily understand the words in the claims. Specifically, the Patent Office expressly requires that a patent application " $[b] \mathrm{e}$ in the English language or be accompanied by a translation of the application ... into the English language together with a statement that the translation is accurate." 218 This procedural rule, by making the meaning of an applicant's claim words more readily accessible to the patent examiner, helps the Office more accurately and efficiently determine the scope of the claim to which the applicant asserts an entitlement.

Our proposed rule, by mandating that all applicants identify on the face of their applications their preferred general and specialized reference sources for defining claim terms, is akin to the "use English or translate" rule. If promulgated, it would help the examiner better understand the scope of the claim that an applicant seeks to patent. Specifically, if an examiner were in doubt about the meaning of a claim word, and thus about the scope of the proposed claim, she could consult the applicant-identified reference sources for assistance. Indeed, such dictionary consultation is fully consistent with the established Patent Office practice of giving a claim term its broadest reasonable construction during examination. ${ }^{219}$ The Federal

217. See Hanna v. Plumer, 380 U.S. 460, 475 (1965) (Harlan, J., concurring) (finding that one can distinguish substantive and procedural rules "by inquiring if the choice of rule would substantially affect ... primary decisions respecting human conduct"); S.A. Healy Co. v. Milwaukee Metro. Sewarage Dist., 60 F.3d 305, 310 (7th Cir. 1995) (Posner, J.) (asserting that a state rule has a substantive goal if it is "designed to shape conduct outside the courtroom and not just improve the accuracy or lower the cost of the judicial process"). We owe this formulation to LAWrence B. SOlum, Procedural Justice 19-21 \& n.49 (U. San Diego, Law \& Econ. Research Paper No. 04-02, 2004), available at http://papers.ssrn.com/sol3/papers.cfm? abstract_id=508282. See also Thomas W. Merrill, The Common Law Powers of Federal Courts, 52 U. CHI. L. Rev. 1, 46 n.200 (1985) ("Substantive rules ... guide the conduct of persons outside the courtroom, before they are drawn into litigation. By negative implication, 'procedural' rules are those that would not affect behavior in ... . 'everyday, prelitigation life.").

218. 37 C.F.R. $\$ 1.52$ (b) (ii); see also $\$ 1.52$ (d) (requiring English translations of non-English applications). There is also a similar provision requiring translation of any non-English documents that parties submit in an interference proceeding at the Patent Office. See $\$ 1.647$.

219. See MPEP, supra note 209, $\$ 2111$, at 2100-46; see also In re Morris, 127 F.3d 1048, 1054, 44 U.S.P.Q.2d (BNA) 1023, 1027 (Fed. Cir. 1997) (“[A]s an initial matter, the PTO applies to the verbiage of the proposed claims the broadest reasonable meaning of the words in their ordinary usage as they would be understood by one of ordinary skill in the art"). The policy justification for this approach is that, if the broadest reasonable construction of a claim term creates a 
Circuit has, in at least three post-Markman cases on direct review from Patent Office rejections, used dictionaries to help establish the broadest reasonable construction of a claim term. ${ }^{220}$ The examiner could also use the reference sources to help explain to the applicant her evaluation of the claim's patentability. Of course, if none of the claim words raised doubts for the examiner that consulting an applicant-identified source would resolve, she might not consult the applicant-identified dictionaries at all. In any event, the dictionaries would have been identified for later use in design-around, licensing, and litigation settings.

We know anecdotally that examiners sometimes cite and quote dictionary definitions in their interactions with patent applicants. ${ }^{221}$ Our proposed rule would thus simply transform a sporadic practice into a regularized one. The rule is procedural because it is aimed at regulating patent applicants' engagement with the machinery of the patent system, not their innovation behavior outside the patent system. Nor would our rule, if adopted, be the first time that the Patent Office has adjusted the application process to take account of the Federal Circuit's post-Markman claim construction jurisprudence. Specifically, in June 2003, the Patent Office modified its regulation requiring an "Abstract" in every application, ${ }^{222}$ first promulgated in $1966,{ }^{223}$ to conform the rule to the Federal Circuit's claim construction case law. ${ }^{224}$ From 1966 to 2003, the rule requiring an abstract had ended with the statement that " $[t]$ he abstract will not be used for interpreting the scope of the claims." ${ }^{225}$ In Hill-Rom Co. $v$. Kinetic Concepts, Inc., however, the Federal Circuit concluded that, notwithstanding the text of the Office's abstract rule, there was "no

patentability problem for the applicant, the applicant has the opportunity to respond to the problem with an appropriate change in claim language. See In re Hyatt, 211 F.3d 1367, 1372, 54 U.S.P.Q.2d (BNA) 1664, 1667 (Fed. Cir. 2000). Indeed, this approach "promotes the development of the written record before the PTO that provides the requisite written notice to the public as to what the applicant claims as the invention." In re Morris, 127 F.3d at 1054, 44 U.S.P.Q.2d at 1027.

220. In re Thrift, 298 F.3d 1357, 1364, 63 U.S.P.Q.2d (BNA) 2002, 2006 (Fed. Cir. 2002); Hyatt, 211 F.3d at 1371, 54 U.S.P.Q.2d (BNA) at 1666; In re Morris, 127 F.3d at 1056, 44 U.S.P.Q.2d (BNA) at 1029.

221. See, e.g., Cordis Corp. v. Medtronics AVE, Inc., 339 F.3d 1352, 1359, 67 U.S.P.Q.2d (BNA) 1876, 1879 (Fed. Cir. 2003) (during reexamination prosecution, the examiner used the definition of the claim word "slots" from Webster's Ninth New Collegiate Dictionary to help explain to the applicant how a prior art reference showed the claimed structure).

222. 37 C.F.R. $\$ 1.72(b)$.

223. 31 Fed. Reg. 12922, 12922 (Oct. 4, 1966) (adopting $§ 1.72(b)$ ).

224. 68 Fed. Reg. 38611, 38614 (June 30, 2003) (describing new rule); id. at 38621 (Comment 18); id. at 38628 (text of new version of 37 C.F.R. $\$ 1.72(\mathrm{~b})$ ).

225. See, e.g., 37 C.F.R. $\$ 1.72$ (b) (1967); 37 C.F.R. $\$ 1.72(b)$ (1983); 37 C.F.R. $\S 1.72(\mathrm{~b})(2003)$. 
legal principle that would require [it] to disregard [a] potentially helpful source of intrinsic evidence as to the meaning of claims."226 The Patent Office expressly relied on Hill-Rom to explain its deletion of the final sentence in its 2003 revision to the rule. ${ }^{227}$ Given the far greater number of times the Federal Circuit has cited a dictionary, compared to a patent abstract, a Patent Office rule regularizing dictionary selection by patent applicants would be even better grounded than this recent change to the abstract requirement.

In sum, a rule mandating that all applicants specify their preferred general purpose and specialized reference sources on the face of their applications falls well within the ambit of the Patent Office's plenary power over examination procedure.

\section{B. There's No Time Like the Filing Date}

It might seem odd, at first blush, to suggest that one should improve a litigation technique by making a change to the start of an administrative process that begins several years earlier. ${ }^{228}$ Upon reflection, however, it is clear that the best time to regularize the selection of objective reference sources for claim construction is the time a patent application is first filed.

First, a dictionary selection policy implemented at the time of filing is comprehensive. All patents result from the examination process. ${ }^{229}$ It is therefore certain that any patent that is in litigation today was the subject of an examination process at some point in the past. In light of this basic fact about patent administration, the best way to ensure that an information-forcing rule such as the one proposed here

226. 209 F.3d 1337, 1341 n.*, 54 U.S.P.Q.2d (BNA) 1437, 1440 n.1 (Fed. Cir. $2000)$.

227. 68 Fed. Reg. at 38614,38621 . Interestingly, this brings the abstract rule full circle: when it was first proposed in 1966, the rule did not include the statement that the Patent Office would not use the abstract for claim construction. 31 Fed. Reg. 4412, 4412 (Mar. 15, 1966) (providing language of proposed Rule 1.75).

228. It takes an average of just over two years for a patent application to mature into an issued patent. U.S. PATENT \& TRADEMARK OfFice, U.S. DeP'T OF COMMERCE, PERFORMANCE AND ACCOUNTABILITY REPORT: FISCAL YEAR 200319 [hereinafter PERFORMANCE REPORT] (reporting average total pendency time of 26.7 months for fiscal year 2003), available at http://www.ustpo.gov/web/offices/com/annual/2003/ index.html. In addition, patentees who sue on their patents typically do so within two to four years of a patent's issue date. See John R. Allison et al., Valuable Patents, 92 GEO. L.J. 435, 454 (2004) (Figure 1). Adding these two typical time periods together, the filing date of a patent application is likely to precede the filing date of a patent suit by about four to six years.

229. 35 U.S.C. $\$ 111$ (2001) (requiring an application); id. $\$ 131$ (requiring examination of the application). 
provides the greatest public benefit is to make it part of the patent examination process. ${ }^{230}$

Second, an application's filing date is one of the key touchstones of every patentability analysis. As has already been noted, the Office cannot evaluate the patentability of a claim without construing the scope of that claim. ${ }^{231}$ The claim itself must therefore be sufficiently definite to make it amenable to construction, and the Patent Act expressly requires that claims be definite. ${ }^{232}$ Claim definiteness is assessed as of the application's filing date. ${ }^{233}$ Similarly, all three doctrines that test a written disclosure's adequacy to support the applicant's claims-best mode, enablement, and written description-are assessed as of the application's filing date. ${ }^{234}$ Finally, the content of the prior art that is used to assess both novelty and nonobviousness is expressly tied, in part, to the application's filing date. ${ }^{235}$ It is plainly appropriate, in light of the filing date's central role in all patentability analysis, to require that a patent applicant

230. See Wagner, supra note 193, at 198-209 (explaining the great importance of information-forcing rules that are put in place at the patent examination stage).

231. See id. at 204 ("Patent scope determinations occur during patent prosecution and during litigation (possibly years apart).") (footnote omitted).

232. 35 U.S.C. $\$ 112$, I 2 ("The specification shall conclude with one or more claims particularly pointing out and distinctly claiming the subject matter which the applicant regards as his invention."); see also MUELLER, supra note 22, at 40-45 (discussing claim definiteness requirement). As the Federal Circuit explained in its recent decision in Honeywell Int'l, Inc. v. Int'l Trade Comm'n, 35 U.S.C. § 112 "requires 'that the claims be amenable to construction, however difficult that task may be." 341 F.3d 1332, 1338, 68 U.S.P.Q.2d (BNA) 1023, 1028 (Fed. Cir. 2003) (quoting Exxon Research \& Eng'g Co. v. United States, 265 F.3d 1371, 1375, 60 U.S.P.Q.2d (BNA) 1272, 1276 (Fed. Cir. 2001)).

233. See W.L. Gore \& Assocs., Inc. v. Garlock, Inc., 721 F.2d 1540, 1556-57, 220 U.S.P.Q. (BNA) 303, 316 (Fed. Cir. 1983) (overturning trial court's conclusion that claims were invalid for indefiniteness, on the ground that "subsequently developed and therefore irrelevant formulae cannot be used to render non-enabling or indefinite that which was enabling and definite at the time the application was filed").

234. Transco Prods. Inc. v. Performance Contracting Inc., 38 F.3d 551, 557, 32 U.S.P.Q.2d (BNA) 1077, 1082 (Fed. Cir. 1994) (best mode); Vas-Cath Inc. v. Mahurkar, 935 F.2d 1555, 1563-64, 19 U.S.P.Q.2d 1111, 1116-17 (Fed. Cir. 1991) (written description); Hybritech Inc. v. Monoclonal Antibodies, Inc., 802 F.2d 1367, 1384, 231 U.S.P.Q. (BNA) 81, 94 (Fed. Cir. 1986) (enablement); see also MUELLER, supra note 22, at 68 ("The patent application must comply with the disclosure requirements when it is filed.").

235. The content of the prior art is determined according to 35 U.S.C. $\S 102$, both for novelty and nonobviousness purposes. See MUELLER, supra note 22, at 94, 139. Subections (b) and (d) are expressly tied to the filing date of the application under review. And subsections (a), (e), and (g), although tied to the invention date of the application under review, often rely on the filing date as a proxy for the invention date: the Patent Office "presumptively treats the applicant's filing date as her invention date (based on a constructive reduction to practice theory) for purposes of applying [subsections] (a), (e), and (g), unless and until the applicant proves an earlier actual invention date." MUELIER, supra note 22, at 95 (footnote omitted). 
identify at that time her preferred objective reference sources for use in claim construction.

Third, mandating that an applicant express his dictionary preferences on the filing date comports with two separate temporal restrictions on a patent's written content. The Patent Act expressly provides that, in the course of amending claims and correcting the supporting disclosure in response to points raised by the patent examiner, an applicant cannot make any substantive addition to the patent disclosure. In the words of the Patent Act, "[n]o amendment shall introduce new matter into the disclosure of the invention." 236 The Patent Act similarly restricts changes to drawings included in a patent. Specifically, section 113 of the Act provides that an applicant "shall furnish a drawing where necessary for the understanding of the subject matter sought to be patented."237 The courts have long looked to drawings for whatever help they provide in construing disputed claim terms. ${ }^{238}$ Importantly, section 113 expressly precludes consulting a post-filing drawing to help construe claim terms: "Drawings submitted after the filing date of the application may not be used ... to supplement the original disclosure thereof for the purpose of interpretation of the scope of any claim." ${ }^{\text {239 }}$ Augmenting these filing-date based restrictions on patent content with a dictionary selection requirement will help keep the focus of the claim construction process on the content of the originally filed patent document.

Fourth, requiring an applicant to name her preferred dictionaries is not, in fact, all that dramatic a departure from current patent drafting or examination practice. For example, experienced patent drafters already advise those who are learning the trade to consult dictionaries and similar sources to ensure a high-quality patent. ${ }^{240}$

236. 35 U.S.C. $\$ 132(a)$. According to Professor Mueller, "The fundamental principle underlying the new matter prohibition is that "the invention described in the original patent [or application] must not be changed.'" MUELLER, supra note 22, at 68 n.14 (quoting In re Oda, 443 F.2d 1200, 1203, 170 U.S.P.Q. (BNA) 268, 270-71 (C.C.P.A. 1971)).

237. 35 U.S.C. $\S 113$.

238. Autogiro Co. v. United States, 384 F.2d 391, 398, 155 U.S.P.Q. (BNA) 697, 703 (Ct. Cl. 1967) ("In those instances where a visual representation can flesh out words, drawings may be used in the same manner and with the same limitations as the specification."); Kemco Sales, Inc. v. Control Papers Co., 93 F. Supp. 2d 563, 570 (D.N.J. 1998) (same), affd, 208 F.3d 1352, 54 U.S.P.Q.2d (BNA) 1308 (Fed. Cir. 2000). Indeed, drawings may be sufficient, by themselves, to provide a written disclosure that supports claims. Vas-Cath, 935 F.2d at 1565,19 U.S.P.Q.2d (BNA) at 1118 (Fed. Gir. 1991) ("[U]nder proper circumstances, drawings alone may provide a "written description" of an invention as required by $\$ 112$. ").

239. 35 U.S.C. \$ 113 (ii).

240. See, e.g., FABER, supra note 196, $\S 19$, at III-16 ("In most cases, the inventor or 
Patentees sometimes expressly rely on particular dictionaries in their patents to help explain the meaning of claim terms. ${ }^{241}$ In addition, we know that examiners sometimes cite dictionaries to applicants to help explain why a claim term should be construed in a particular manner. ${ }^{242}$ It is safe to conclude, on the basis of these informal, occasional practices, that patent practitioners will readily adapt to the dictionary selection requirement we propose.

Fifth, and finally, one might still object that dictionary selection at the filing stage is unworkable because, at that time, the applicant lacks the context necessary to make a meaningful choice among competing reference sources-context that a live dispute with another party about claim scope would provide. However, this objection simply denies the wisdom in the Federal Circuit's view that it is better to enrich claim construction with reference sources that are "not colored by the motives of the parties" to a dispute, "and not inspired by litigation." ${ }^{243}$ If reference sources are to be more than mere props in a post hoc justification game, patentee pleas for "more context" should be set aside.

\section{Changing Patent Office Rules to Regularize Dictionary Choice}

To make dictionary consultation more predictable, for designaround, licensing, and litigation purposes, the Patent Office should require all patent applicants to state their dictionary preferences (general purpose and specialized) on the face of their patent applications at the time they file them. Such a rule is well within the Patent Office's regulatory power over examination procedure, ${ }^{244}$ and

a mechanical dictionary can supply the precise name for a part in any specific embodiment."); JeFFrey G. SHELDON, How To WRITE A PATENT APPLICATION $\$$ 6.3.5.1.3, at 6-32 (PLI Press, 2001) ("A thesaurus and a dictionary are indispensable tools for the practitioner and should be frequently referred to when preparing the claims.").

241. See, e.g., U.S. Patent No. 4,972,909 (issued Nov. 27, 1990) at col. 1, 1l. 50-60 (citing WebsTER's THIRD NeW INTERNATIONAL DictionaRY (G\&G Merriam 1967) to help define claim term "caulk," spelled "caulk" in the dictionary), at http://www. uspto.gov (on file with the American University Law Review); U.S. Patent No. 6,708,400 (issued Mar. 23, 2004) at col. 7, 1l. 32-40, at http://www.uspto.gov (on file with the American University Law Review) (quoting Webster's New Collegiate Dictionary to help define claim term "particulate"),

242. See In re Hyatt, 211 F.3d 1367, 1372, 54 U.S.P.Q.2d (BNA) 1664, 1667 (Fed. Cir. 2000) (discussing the examiner's use of Webster's New International Dictionary to give the term "sharing" its broadest common meaning).

243. Tex. Digital Sys., Inc. v. Telegenix, Inc., 308 F.3d 1193, 1203, 64 U.S.P.Q.2d

(BNA) 1812, 1818 (Fed. Cir. 2002).

244. See supra Part III.A. 
the time of filing is an appropriate one at which to require applicants to state their preferences. ${ }^{24}$

The new regime we propose would be more predictable than the effectively random approach to choosing dictionaries that the courts, including the Federal Circuit, use now. There will, of course, be a cost to achieving this increased predictability. Is this cost offset by at least as large a savings in patent licensing and litigation costs, such that our proposed change yields a net social benefit? We think it is. Admittedly, as is usually the case in such patent reform discussions, we can offer only the roughest estimates of our proposal's costs and benefits. ${ }^{246}$ These estimates, however, make quite a persuasive case.

The primary cost of implementing our proposal, apart from the initial cost of promulgating the regulation itself, would be the increased cost of preparing a patent application for initial filing. Specifically, the patent drafter would take some time to determine which reference sources are preferable for the application at hand and pass along the cost of this time to her client. ${ }^{247}$ In estimating this cost, one must keep in mind two important background facts.

First, the drafter's additional cost of choosing reference sources for a single application is likely to be very low. Above an obvious minimum quality threshold, the precise identity of the reference sources named matters far less than the simple fact that some specific sources are named (thereby eliminating uncertainty about which sources the courts will consult if litigation occurs). That this is so becomes plain when one considers the fact pattern that prompts one to turn to dictionaries in the first place: namely, the inevitable occasion where one wants more guidance on the meaning of a claim term than the patent itself provides, because the drafter did not foresee the need to choose a more precise word or phrase to cover the point in question. Of course, where the drafter did foresee the need for a precise word or phrase, she consulted the appropriate reference sources to ensure proper word choice or, alternatively,

245. See supra Part III.B.

246. See generally Mark A. Lemley, Rational Ignorance at the Patent Office, 95 Nw. U. L. REV. 1495 (2001) (arguing that revising the patent review procedures to require a more thorough examination of all patent applications is unnecessary given that litigation occurs for only a minority of patents and that most patents are never licensed). Only rough estimates are possible concerning our proposal because there are no reliable data on (a) how many patents are licensed, (b) how much it costs, on average, to negotiate a patent license, (c) how many patents, whether licensed or not, are the subject of formal infringement or validity analysis, or (d) how much it costs, on average, to conduct such a formal analysis. Id. at 1507-08.

247. In the context of in-house counsel, who do not bill the client in this manner, the cost is born in the form of a reduced number of applications the drafter can prepare in a given unit of time. 
drafted express definitions for inclusion in the body of the patent. The cost of thoroughly addressing foreseeable scenarios is already a cost of patent preparation today, and it would continue to be a cost of patent preparation were our proposal adopted. Given that we turn to dictionaries to cope with the unforeseeable, it makes little sense for a patent applicant to invest more in choosing dictionaries than it takes to identify one or two sources with a good, solid reputation. So, for example, a rational patent drafter will not choose a dictionary by looking up every word in a draft claim in several dictionaries in an effort to see which one is "best."

Second, however high or low the drafter's additional cost of reference source selection may be for a single application, the drafter spreads that cost over a large number of patent applications involving similar technology. As a result, the average cost of dictionary selection will be far lower than the cost of dictionary selection for the first application a drafter prepares in a given technology.

It is possible, against this backdrop, to give a rough estimate of the annual increased patent preparation cost that our proposal entails. According to the American Intellectual Property Law Association's ("AIPLA") most recent biennial survey of, among other things, patent prosecution and litigation costs, the national median costs of preparing and filing "relatively complex" applications in the three main technological areas are as follows: (a) biotechnology/chemical, $\$ 10,001$; (b) electrical/computer, $\$ 9,995$; and (c) mechanical, $\$ 8,001{ }^{248}$ The average median cost across these technologies is $\$ 9,332.33$. Assume, for purposes of this analysis, that selecting reference sources increases the average preparation cost by $1 \%$, or $\$ 93.32$, per application. ${ }^{249}$ The Patent Office receives just over 330,000 utility patent applications a year, ${ }^{250}$ about $28 \%$ of which are continuation applications, ${ }^{251}$ i.e., applications that simply re-initiate

248. AIPLA, REPORT OF THE ECONOMIC SURVEY 88 tbl. 21 (2003) [hereinafter SURVEY].

249. We think this estimate is actually far higher than would likely be the case, and thus overstates the cost of our proposal. If, however, the benefits of the proposal outweigh even this overstated cost, we can be confident that the proposed change produces a net social benefit.

250. See PERFORMANCE REPORT, supra note 228, at 106 tbl. 1 (providing a summary of patent examining activities for the fiscal years 1999-2003). In particular, from 2001-2003, the U.S. Patent and Trademark Office received over 330,000 patent applications per year. Id. However, in 1999 and 2000, the Patent Office received under 330,000 patent applications. Id.

251. The principal empirical study of these applications reports that, during fiscal years 1993-1998, "28.4\% of the utility, plant, and reissue (UPR) applications in those years were not new or original applications, but were continuing applications claiming the benefit of the filing dates of previously filed applications." Cecil $D$. Quillen, Jr. \& Ogden H. Webster, Continuing Patent Applications and Performance of the 
the examination process on an application that was filed at least once before. $^{252}$ Of course, an application will entail the dictionary selection cost only the first time it is filed. Using the one percent increase assumption, then, we estimate the annual increase in preparation cost to be $\$ 22,172,832 .{ }^{259}$

Would making dictionary selection part of the patent examination process save at least $\$ 22.2$ million a year? We think it would. One source of savings would be court cases that are not filed at all because greater agreement on the likely construction of an arguable claim term makes litigation unnecessary. According to the AIPLA's most recent biennial survey, the national median cost of a full patent trial in which $\$ 1$ to $\$ 25$ million is at risk is $\$ 2$ million per side, i.e., $\$ 4$ million. ${ }^{254}$ If six such trials are avoided every year, the new rule has both paid for itself and yielded a small social benefit; additional avoided trials are pure benefit. Given that about 1,900 utility patent infringement cases are filed every year, ${ }^{255}$ and that about ninety-five of these cases are fully tried, ${ }^{256}$ avoiding six trials does not seem like that tall an order. Alternatively, the national median cost of taking through discovery a patent infringement case in which $\$ 1$ to $\$ 25$ million is at risk is $\$ 1,001,000$ per side, i.e., $\$ 2$ million. ${ }^{257}$ If twelve such cases are avoided every year, the new rule has both paid for itself and yielded a small social benefit. Again, this is not too high a hurdle, given the 1,600 cases filed annually. Given that the Federal Circuit used dictionaries to help construe claim terms in twenty-six separate appeals in 2003 , and another twenty separate appeals in the

U.S. Patent and Trademark Office, 11 FeD. CIR. B.J. 1, 3 (2001); see also id. at 16 tbl.1. The Quillen \& Webster data group utility patent applications with plant and reissue applications. Id. at 3. Only the utility applications, however, are of interest in this study. Their $28 \%$ figure remains a good estimate for continuing applications for utility patents alone because reissue and plant patent applications make up such a small portion of the total number of applications filed in a given year. For example, in fiscal year 2003, the Patent Office received 331,729 utility applications, 785 plant applications, and 938 reissue applications. PERFORMANCE REPORT, supra note 228, at 106 tbl. 1. Similarly, in fiscal year 2002, the Patent Office received 331,580 utility applications, 1,134 plant applications, and 974 reissue applications. Id.

252. For a concise explanation of continuation applications in U.S. patent practice, see Quillen, Jr. \& Webster, supra note 251, at 4-6.

253. (330,000 applications per year) $\times(72 \%$ originally filed) $\times(\$ 93.32$ per application) $=\$ 22,172,832.00$ per year.

254. SURVEY, supra note 248 , at 93 tbl. 22.

255. See Kimberly A. Moore, Forum Shopping in Patent Cases: Does Geographic Choice Affect Innovation?, 79 N.C. L. REV. 889, 903 tbl. 1 (2001) (indicating that, from 1995 to 1999 , district courts resolved about 1,900 utility patent infringement cases per year).

256. See Kimberly A. Moore, Judges, Juries, and Patent Cases-An Empirical Piece Inside the Black Box, 99 MiCH. L. REv. 365, 384 \& tbl. 1 (2000) (reporting that from 1983 to 1999 , the annual number of full patent trials ranged from a low of seventy-three to a high of 112, with an average of ninety-five).

257. SURVEY, supra note 248 , at 93 tbl. 22. 
first half of 2004 , it seems safe to conclude that the annual litigation savings that our proposal would generate would more than cover the cost of requiring all applicants to state their dictionary preferences.

Another source of savings would be less costly license negotiations. The savings mechanism in licensing, as in avoided litigation, is greater agreement among the parties on the likely construction of an arguable claim term. There are virtually no reliable data about how many of the roughly 180,000 patents that issue each year ${ }^{258}$ are licensed for revenue. ${ }^{259}$ Professor Lemley, in his study of the costs and benefits of various patent law reform proposals, estimates that about $3.5 \%$ of issued patents are licensed for revenue, and that the cost to an industry of negotiating a license with the patentee is $\$ 100,000 .^{260}$ Using these assumptions, along with an estimate that the identification of dictionaries on the face of the patent lowers the licensing cost by one percent, the annual savings is $\$ 6,300,000{ }^{261}$ This licensing savings alone covers twenty-eight percent of the increased patent preparation cost of our proposal. Using a licensing cost discount of $5 \%$, which we think is more likely, our proposed rule generates an annual licensing cost savings of $\$ 31,500,000,{ }^{262}$ i.e., $142 \%$ of the estimated increase in annual patent preparation costs.

Finally, a key source of savings would be avoided dead weight loss, achieved through more effective competition against patentees from those who have designed around their patents. Dictionaries named on the face of all patents will reduce the uncertainty of a competitor's analysis of the scope of the claim; the reduced uncertainty will, in turn, facilitate more rapidly achieved and more numerous designarounds. Competition from these design-arounds will help drive down the patentee's price to marginal cost, thereby helping trim dead weight loss. It is impossible to estimate the size of this effect, but it seems hard to imagine that it would fall below $\$ 22.2$ million per year in an economy as vast as our own. This savings from enhanced certainty, moreover, takes nothing from a patentee that she is

258. See PERformance RePort, supra note 228, at 106 tbl. 1 (reporting the annual number of allowed patents for the fiscal years 1999-2003, however failing to note how many of those patents were licensed for revenue). From 1999-2003, the number of allowed patent applications rose from year to year, averaging out to 186,607 applications per year. $I d$.

259. See Lemley, supra note 246, at 1507 (noting the lack of accurate data regarding patents licensed for revenue).

260. Id. at 1507-08.

261. (180,000 patents per year) $\times(3.5 \%$ licensed $) \times(\$ 100,000$ per license $) \times(1 \%$ savings per license) $=\$ 6,300,000$ savings per year.

262. (180,000 patents per year) $\times(3.5 \%$ licensed $) \times(\$ 100,000$ per license $) \times(5 \%$ savings per license) $=\$ 31,500,000$ savings per year. 
entitled to keep. One of the core policies underlying the public notice function that clear claim language serves is the desirability of facilitating design-arounds by the patentee's competitors. ${ }^{263}$ As the Federal Circuit observed more than a decade ago, "[d]esigning around patents is, in fact, one of the ways in which the patent system works to the advantage of the public in promoting progress in the useful arts, its constitutional purpose.,"264

It appears, from these three savings sources alone, that moving dictionary selection from the litigation stage (where it is effectively random) to the examination stage (where it greatly reduces uncertainty for every patent throughout its term) will generate important social benefits. The Patent Office should make this change to the patent examination rules without delay. It can do so in two stages. We discuss both in turn, beginning with the long-term solution at which the Patent Office should aim. ${ }^{26 .}$

\section{Changing the application content rule to require dictionary selection}

We think the ultimate goal at which the Patent Office should aim is a change to the existing rules governing what an applicant must include in her application on the day it is filed. The existing rules, codified in Title 37 of the Code of Federal Regulations, ${ }^{266}$ are the result of notice-and-comment rulemaking. The change we proposea requirement that an applicant name her preferred reference

263. See Mark A. Lemley \& Kimberly A. Moore, Ending Abuse of Patent Continuations, 84 B.U. L. REv. 63, 95 n.126 (2004) (explaining that design-arounds benefit the public by encouraging progress in the marketplace through the creation of new and innovative advances and variations of the patented product); Craig Allen Nard, A Theory of Claim Interpretation, 14 HARV. J.L. \& TECH. 1, 40-43 (2000) (noting that when a competitor plans to design around a patented product, he or she seeks to create a product that will not result in an infringement suit).

264. Slimfold Mfg. v. Kinkead Indus., 932 F.2d 1453, 1457, 18 U.S.P.Q.2d (BNA) 1842, 1845-46 (Fed. Cir. 1991).

265. The specific suggestions we make here are predicated on the current state of the law. Depending on how the Federal Circuit resolves the Phillips case, see supra notes 17-18 and accompanying text, some of the details of our proposal might require adjustment.

266. The most natural locus for our proposed change is 37 C.F.R. $\$ \$ 1.71-1.79$ (2005), a cluster of rules called "Specification." A patent specification requires, among other things, a written description of the invention or discovery $(\$ 1.71)$ setting forth what the applicant seeks to patent in a manner that distinguishes it from other inventions $(\$ 1.71)$; a title of the invention or discovery $(\S 1.72)$; a summary of the nature and substance of the invention $(\$ 1.73)$; and one or more claims that define the scope of the invention $(\$ 1.75)$. One could also make our proposed change by modifying the rules governing the "information disclosure statement," a form that applicants use to tell the Patent Office about prior art references of which she is aware. See $\$ \S 1.97-1.98$ (providing the guidelines that qualify an applicant to issue an "information disclosure statement" and also explaining what the "information disclosure statement" must include). 
sources, both general and specialized, on the face of the application-also requires notice-and-comment rulemaking, such that it will have the force of law and bind all applicants. ${ }^{267}$

This new dictionary selection requirement need not limit applicants in their choice of sources, either in name or number. If the applicant names a source that the Patent Office does not yet possess, it can acquire the title in keeping with its congressional mandate to maintain an effective library. ${ }^{268}$ In short order, any existing gaps in the Office's reference library will be filled. If the applicant wants to commit in advance to using many dictionaries of a given type (e.g., by naming two or three general purpose English language sources), we can think of no reason to disallow the practice at the outset. Of course, the same tension that today sharpens the choice between broad language (which covers more potential infringements, and is also more vulnerable to prior art-based invalidity attacks) and narrow language (which covers fewer potential infringements, and is also less vulnerable to prior art-based invalidity attacks) will also sharpen the choice between naming more and fewer dictionaries. We think it likely that most applicants will name one or two general purpose and one or two specialized reference sources. If, after monitoring the practice for a year or two, the Patent Office finds that applicants are overwhelming the system with too many reference source designations, it can revisit the question whether to cap the number of reference sources an applicant may name.

\section{Changing examiner practice to require dictionary identification}

In the interim, as the notice-and-comment process plays out, the Patent Office should immediately change the Manual of Patent Examining Procedure to direct all examiners to state, in the first response from the Office that is sent to the applicant, the general purpose and specialized reference sources the examiner will use to construe claim words should any doubts about claim scope arise. This rule, which would bind examiners but not applicants, can be implemented without notice-and-comment rulemaking. ${ }^{269}$ Should an

267. See supra notes 197-201 and accompanying text (explaining the Patent Office's power to promulgate binding procedural rules).

268. See 35 U.S.C. $\$ 7$ (2002) ("The Director shall maintain a library of scientific and other works and periodicals, both foreign and domestic, in the Patent and Trademark Office to aid the officers in the discharge of their duties.").

269. See 5 U.S.C. $\$ 553(\mathrm{~b})$ (A) (2002) (providing that notice-and-comment rulemaking is not required for "interpretive rules, general statements of policy, or rules of agency organization, procedure, or practice"). The Patent Office regularly relies on this exception to the notice-and-comment rulemaking requirement when promulgating examination guidelines that are directed at the examiner corps. See, 
applicant object to the use of the reference sources that the examiner chooses, the applicant can designate alternative reference sources. In addition, the Patent Office should adapt the existing rules ensuring that any prior art that the examiner identifies during the examination process also appears on the face of the patent, ${ }^{270}$ so that the examiner-identified reference sources (or their applicantidentified substitutes) also appear on the face of any resulting patent.

\section{The undesirability of an official dictionary list}

It is worth pausing for a moment, in this discussion of integrating dictionary selection into the patent examination process, to consider why the Patent Office should not prescribe a closed list of reference sources after conducting a formal proceeding to determine which reference sources are most reliable for each main technological area. ${ }^{271}$ First, this top-down approach cuts against the general grain of the patent process, which is quite applicant-driven. ${ }^{272}$ Second, a topdown approach is on the wrong side of a basic information asymmetry: applicants, who know far more about the current state of the art in their fields than do patent examiners, ${ }^{273}$ are in the best position to choose the most up-to-date, high-quality dictionaries and similar sources. Third, a centralized selection process would needlessly divert resources from other Patent Office needs. Indeed, the more the selection process sought to overcome the information asymmetry just described, the more costly it would be. And the expense would be incurred time and again as the Patent Office

e.g., U.S. Patent \& Trademark Office, Utility Examination Guidelines, 66 Fed. Reg. 1092, 1092 (Jan. 5, 2001) ("Because these Guidelines only govern internal practices, they are exempt from notice and comment rulemaking under 5 U.S.C. 553(b) (A).").

270. See MPEP, supra note 209, $\$ 707.05$, at 700-12 (providing that the patent examiner should consider and cite prior art which is related to the claims asserted in the patent application); id. $\$ 1302.12$, at 1300-13 (encouraging the patent examiner to cite related art for allowed patent applications).

271. See Wagner, supra note 193. As we noted earlier, Professor Wagner may have suggested something along these lines. Id. However, because his proposal occupies only two or three sentences, it is difficult to be certain. Id. at $244 \& \mathrm{c} n .311$.

272. For example, it is the applicant, not the Patent Office, who prompts examination by drafting and filing an application. See 35 U.S.C. $\$ 111$ (indicating that it is the inventor or someone authorized by the inventor who actually files the patent application). And it is the applicant who, after receiving notice from the Patent Office of the problems with her application, submits new claims and other amendments to correct the problems. 35 U.S.C. $\$ 132(a)$.

273. See Wagner, supra note 193, at 206-09 (discussing the litigation process of patent cases). During the "prosecution history phase," the patentee provides information to the Patent Office. Id. at 206-07. Because the patentee is required to provide the most accurate information it has regarding the innovation, the prosecution history also tends to be an accurate source of information. Id. at 207. 
regularly updated its list of prescribed reference sources. In short, this "official list" game would not be worth the candle.

\section{CONCLUSION}

The Federal Circuit has put dictionary consultation at the heart of its claim construction jurisprudence. This practice is not likely to change. A dictionary-friendly approach to claim construction has neutrality and predictability goals that are both worthy and attainable. These goals cannot be fully realized, however, until the choice of dictionary is made something more than a capricious, post hoc exercise at the courthouse. The Patent Office thus has a vital regulatory role to play in making dictionary selection a routine applicant-driven, pre-dispute process. The Patent Office should, in short, act quickly and decisively to make dictionary choice as central to patent examination as it has already become to patent litigation. 
POSTSCRIPT: THE DECISION IN PHILLIPS V. AWH CORP.

Just before this Article went to press, the Federal Circuit issued its en banc decision on claim construction methodology in Phillips $v$. AWH Corp.,${ }^{274}$ concluding a rehearing that was ordered while this Article was in draft. ${ }^{275}$ Phillips rejects the Telegenix decision's use of dictionaries as a universal, necessary first step in claim construction. ${ }^{276}$ After a brief review of the court's decision in Phillips, we consider the evidence that courts are likely to continue to rely on dictionaries to construe claims. We also conclude, given Phillips' continued commitment to de novo review in claim construction and utter silence about how courts should select from among multiple pertinent dictionaries, that there is as great a need as ever for the Patent Office to help make dictionary selection in claim construction more predictable with regulations of the type we propose.

The Federal Circuit, capturing the essence of the several questions it had posed in its order directing en banc review, ${ }^{277}$ framed the "principal question in" Phillips as "the extent to which [courts] should resort to and rely on a patent's specification in seeking to ascertain the proper scope of its claims." in Markman $^{279}$ and Vitronics, ${ }^{280}$ as well as a more recent decision in Innova/Pure Water, ${ }^{281}$ for special "reaffirm[ation]," 282 the court emphasized that "the person of ordinary skill in the art is deemed to read the claim term not only in the context of the particular claim in which the disputed term appears, but in the context of the entire patent, including the specification." ${ }^{283}$ The two overarching principles that frame the claim construction process, discussed

274. Nos. 03-1269, 03-1286, 2005 WL 1620331 (Fed. Cir. July 12, 2005) (en banc).

275. See supra notes $17-18$ and accompanying text.

276. $2005 \mathrm{WL} 1620331$, at $* 11-* 16$. For our analysis of the Telegenix discussion about using objective reference sources in claim construction, see supra notes 73-84 and accompanying text.

277. See 376 F.3d 1382, 1383 (Fed. Cir. 2004) (setting forth seven groups of questions for additional briefing).

278. 2005 WL 1620331 , at $* 4$.

279. See Markman v. Westview Instruments, Inc., 52 F.3d 967 (Fed. Cir. 1995) (en banc), aff'd, 517 U.S. 370 (1996). For our analysis of Markman's discussion about using objective reference sources in claim construction, see supra notes 54-58 and accompanying text.

280. See Vitronics Corp. v. Conceptronic, Inc., 90 F.3d 1576 (Fed. Cir. 1996). For our analysis of Vitronics' discussion about using objective reference sources in claim construction, see supra notes 59-72 and accompanying text.

281. See Innova/Pure Water, Inc. v. Safari Water Filtration Sys., Inc., 381 F.3d 1111 (Fed. Cir. 2004).

282. 2005 WL 1620331 , at *4; see also id. at *16.

283. Id. at *5. 
above, ${ }^{284}$ remain the same: "the words of a claim 'are generally given their ordinary and customary meaning," 285 and "the ordinary and customary meaning of a claim term is the meaning that the term would have to a person of ordinary skill in the art in question at the time of the invention, i.e., as of the effective filing date of the patent application." 286 According to the court, a term's ordinary and customary meaning "provides an objective baseline from which to begin claim construction." term that the patent specification and prosecution history provide remains central to the process throughout. ${ }^{288}$ Indeed, the "specification's virtue" is that it was "created at the time of patent prosecution for the purpose of explaining the patent's scope and meaning." 289

What of dictionaries and other objective reference sources, which are extrinsic to the particularized context of the specification and prosecution history? Can courts continue to use such reference sources to help construe claims? On this point, the court struck a more complex balance. On the one hand, the court reaffirmed its basic approval of court use of objective reference sources extrinsic to the patent, such as dictionaries and technical treatises, for the background information they provide to generalist judges facing unfamiliar technology. "Because dictionaries, and especially technical dictionaries, endeavor to collect the accepted meanings of terms used in various fields of science and technology," the court opined, "those resources have been properly recognized as among the many tools that can assist the court in determining the meaning of particular terminology to those of skill in the art of the invention." 290 Moreover, even "general purpose dictionaries may be helpful" when, for example, "the ordinary meaning of claim language as understood by a person of skill in the art may be readily apparent even to lay judges." ${ }^{291}$ In short, so long as it "keep[s] in mind the flaws inherent in each type of evidence," a district court is permitted

284. See supra notes $36-40$ and accompanying text.

285. 2005 WL 1620331, at *5 (quoting Vitronics Corp. v. Conceptronic, Inc., 90 F.3d 1576, 1582 (Fed. Cir. 1996)).

286. Id.

287. Id.

288. Id. at $* 6 * 9$.

289. Id. at $* 11$.

290. Id. at *10; see also id. at *11 ("extrinsic evidence," such as dictionaries, "can help educate the court regarding the field of the invention and can help the court determine what a person of ordinary skill in the art would understand claim terms to mean").

291. Id. at *6. In such a case, claim construction "involves little more than the application of the widely accepted meaning of commonly understood words." Id. 
"in its sound discretion to admit and use such [extrinsic] evidence.,"292 The result in Phillips is, in this respect, as we predicted. ${ }^{293}$

On the other hand, the Phillips court repudiated the more extrinsic-directed, always-consult-a-dictionary-first methodology that the Telegenix case had prescribed. ${ }^{294}$ After recounting the Telegenix methodology's focus on dictionaries, according to which "the specification should be consulted only after a determination is made, whether based on a dictionary, treatise, or other source, as to the ordinary meaning or meanings of the claim term in dispute," ${ }^{295}$ the court rejected the methodology as "improperly restrict[ing] the role of the specification in claim construction." " $[\mathrm{t}]$ he main problem with elevating the dictionary to such prominence is that it focuses the inquiry on the abstract meaning of words rather than on the meaning of claim terms within the context of the patent." ${ }^{297}$ As a result, "too often [the Telegenix] line of cases has been improperly relied upon to condone the adoption of a dictionary definition entirely divorced from the context of the [patent's] written description." ${ }^{\text {298 }}$ The compulsory methodology of Telegenix has thus been rejected. The intrinsic patent materials, not extrinsic evidence that may help one understand them, are restored as claim construction's touchstone. Interestingly, neither the authoring judge in Telegenix, Judge Linn, ${ }^{299}$ nor any of the six heavy dictionary citers we identify in our study, ${ }^{300}$ wrote separately in Phillips to take issue with this repudiation of Telegenix.

The court in Phillips effectively dials its claim construction jurisprudence back to October 15, 2002, just before Telegenix was decided. And Telegenix itself is rejected as a dead end detour. In light of this result, will district courts and the Federal Circuit continue to rely on dictionaries to construe claims? Existing evidence

292. Id. at *11; see also id. at *15 ("As we have noted above, however, we do not intend to preclude the appropriate use of dictionaries.").

293. See supra notes $185-186$ and accompanying text.

294. See supra note 83 and accompanying text.

295. 2005 WL 1620331 , at *13.

296. Id.

297. Id. at *14.

298. Id.

299. See Texas Digital Sys., Inc. v. Telegenix, Inc., 308 F.3d 1193, 1197 (Fed. Cir. 2002).

300. See infra Tbl. 7, App. B. Judge Lourie, who frequently cited dictionaries in his claim construction opinions for the court, did write separately in Phillips. He did so, however, to dissent from the court's construction of the particular claim term in question, not to take issue with the court's general claim construction methodology. See 2005 WL 1620331 , at $* 20-22$ (Lourie, J., dissenting in part). With regard to methodology, Judge Lourie "fully join[ed]" Judge Bryson's opinion for the court. Id. at $* 20$. 
suggests that they will, and at a significant rate. First, as our own data show, by 2002 the Federal Circuit was issuing, on average, more than two claim construction decisions a month that relied on dictionaries and similar sources to construe claim terms. ${ }^{301}$ The case law that preceded Telegenix was thus adequate to support a significant rate of reliance on dictionaries. If litigation parties and the judges who hear their cases continue to find dictionaries useful, courts will continue to rely on them.

Second, two other claim construction decisions bracket the Phillips decision-one just before, and one just after-and both make. use of dictionaries to construe claim terms. Thirteen days before Phillips, the Federal Circuit issued its decision in Seachange Intermational, Inc. $v$. C-Cor, Inc. ${ }^{302}$ In Seachange, written by Judge Linn (the author of Telegenix) for a panel that includes Judge Bryson (the author of Phillips), the court overturned a district court's constructions of three disputed claim terms. ${ }^{303}$ In explaining its rationale for each of the three terms, the Federal Circuit cited and quoted from The New IEEE Standard Dictionary of Electrical and Electronics Terms (5th ed. 1993). ${ }^{304}$ Two days after Phillips, the Federal Circuit issued its decision in North American Container, Inc. v. Plastipak Packaging, Inc. ${ }^{305}$ In Plastipak, written by Judge Lourie for a panel that includes Judge Bryson (the author of Phillips) and Judge Linn (the author of Telegenix), the court affirmed a district court's construction of the claim term "generally convex." definition for "generally" provided by the Oxford English Dictionary Online. ${ }^{307}$ The Federal Circuit agreed, concluding that "the court articulated a common-sense understanding of the term ['generally'] confirmed by a dictionary." 308 These cases show the truth in Phillips' insistence that it "do[es] not intend to preclude the appropriate use of dictionaries." 309

Third, Phillips, like Vitronics before it, praises dictionaries for their objectivity. According to Phillips,

301. See supra Tbl. 4.

302. Nos. 04-1375, 04-1498, 2005 WL 1523382 (Fed. Cir. June 29, 2005).

303. Id. at $* 1$.

304. Id. at *4 (quoting defintion of "network"), *12 (quoting definition of "distributed system"), *13 (quoting definition of "CPU"). According to our data, this is the third most frequently cited technical source on which the Federal Circuit relied. See supra Tbl.6, App. B.

305. Nos. 04-1306, 04-1307, 2005 WL 1645620 (Fed. Cir. July 14, 2005).

306. Id. at *1.

307. Id. at $* 5$.

308. Id. at $* 10$.

309. Nos. 03-1269, 03-1286, 2005 WL 1620331, at *15 (Fed. Cir. July 12, 2005) (en banc). 
Dictionaries or comparable sources are often useful to assist in understanding the commonly understood meaning of words and have been used both by our court and the Supreme Court in claim interpretation. A dictionary definition has the value of being an unbiased source "accessible to the public in advance of litigation." $\$ 110$

Phillips, like Vitronics, also highlights the risk of partisan slant that diminishes the value of expert testimony, observing that, because expert testimony "is generated at the time of and for the purpose of litigation," it "can suffer from bias that is not present in intrinsic evidence." Gi1 Given that ordinary and customary meaning must be determined, and that expert testimony continues to bear the taint of comparatively greater bias, one must expect some courts to prefer dictionaries as sources for ordinary meaning. ${ }^{312}$ Both parties and courts can thus draw strong support from Phillips itself to justify continued reliance on dictionaries in claim construction, so long as they avoid the dictionary-first method of Telegenix, now condemned for its perceived excess.

One cannot help but wonder whether, assuming courts do continue to use dictionaries to help construe disputed claim terms at something like 2002 levels, the courts' selections from among available reference sources will become more predictable than the chaotic pattern that our study documents. We think not. As we have explained, the pre-Phillips case law offers no guidance on how to select from among multiple pertinent reference sources, and offers conflicting signals on how to synthesize a single definition using the content from multiple sources. ${ }^{313}$ Phillips, for its part, offers no

310. Id. (quoting Vitronics Corp. v. Conceptronic, Inc., 90 F.3d 1576, 1585 (Fed. Cir. 1996)) (citation omitted). As we discussed above, supra notes 69-72 and accompanying text, Vitronics emphasized the relative objectivity and reliability of dictionaries to help explain the court's greater solicitude for dictionaries compared to expert testimony. By reaffirming that premise in Phillips, the court once again invites greater reliance on objective reference sources than expert witnesses.

311. 2005 WL 1620331, at *11; see also supra notes 69-72 and accompanying text.

312. See MSM Invs. Co. v. Carolwood Corp., 259 F.3d 1335, 1339 n.* (Fed. Cir. 2001) ("Standard dictionary definitions indicate ordinary meaning."); Dow Chem. Co. v. Sumitomo Chem. Co. Ltd., 257 F.3d 1364, 1373 (Fed. Cir. 2001) ("Thus, in determining the ordinary meaning of a technical term, courts are free to consult scientific dictionaries and technical treatises at any time."); Optical Disc Corp. v. Del Mar Avionics, 208 F.3d 1324, 1334-35 (Fed. Cir. 2000) ("Without evidence in the patent specification of an express intent to impart a novel meaning to a claim term, the term takes on its ordinary meaning. For such ordinary meaning, we turn to the dictionary definition of the term.") (citation omitted); Quantum Corp. v. Rodime, PLC, 65 F.3d 1577, 1581 (Fed. Cir. 1995) ("[W]e see no error in the district court's use of dictionary definitions to ascertain the ordinary meaning of the relevant claim limitation.").

313. See supra notes 116-130 and accompanying text, and notes 160-179 and accompanying text. 
guidance on how courts or parties should select dictionaries or other reference sources, other than expressing a mild preference for technical over general purpose dictionaries ${ }^{314}$ and using the patent application's effective filing date as the relevant anchoring date. ${ }^{315}$ Phillips also sidesteps the opportunity to reconsider whether the Federal Circuit should engage in de novo review of lower court claim construction rulings, ${ }^{316}$ a question on which it had ordered additional briefing. ${ }^{317}$ The unpredictability of trial court use of dictionaries is thus compounded by further unpredictability in Federal Circuit use of dictionaries on de novo review. Judge Mayer's dissent in Phillips decries this very unpredictability. ${ }^{318}$ Indeed, as Professor Wagner has observed, ${ }^{319}$ the rule of Phillips is that, in claim construction, there are no rules. Phillips states that "there is no magic formula or catechism for conducting claim construction. Nor is the court barred from considering any particular sources or required to analyze sources in any specific sequence, as long as those sources are not used to contradict claim meaning that is unambiguous in light of the intrinsic evidence. ${ }^{320}$ This approach maximizes the Federal Circuit's flexibility

314. 2005 WL 1620331 , at $* 10$.

315. Id. at *5.

316. Id. at $* 20$.

317. See 376 F.3d 1382, 1383 (Fed. Cir. 2004) (en banc order) (questioning "is it appropriate for this court to accord any deference to any aspect of trial court claim construction rulings?").

318. See 2005 WL 1620331, at *26 (Mayer, J., dissenting) (

If we persist in deciding the subsidiary factual components of claim construction without deference, there is no reason why litigants should be required to parade their evidence before the district courts or for district courts to waste time and resources evaluating such evidence.... If the proceedings before the district court are merely a tryout on the road, as they are under our current regimen, it is wasteful to require such proceedings at all. Instead, all patent cases could be filed in this court; we would determine whether claim construction is necessary, and, if so, the meaning of the claims.

) (internal quotations and citations omitted).

319. See R. Polk Wagner, Phillips Analysis, Part 1: The New Rule Is There Are No Rules, (July 15, 2005), at http://www.polkwagner.com (on file with the American University Law Review). Judge Mayer, in his dissent in Phillips, makes a similar point:

[A]fter proposing no fewer than seven questions, receiving more than thirty amici curiae briefs, and.whipping the bar into a frenzy of expectation, we say nothing new, but merely restate what has become the practice over the last ten years-that we will decide cases according to whatever mode or method results in the outcome we desire, or at least allows us a seemingly plausible way out of the case.

2005 WL 1620331 , at $* 22$.

320. 2005 WL 1620331, at *16; see also id. ("In Vitronics, we did not attempt to provide a rigid algorithm for claim construction, but simply attempted to explain why, in general, certain types of evidence are more valuable than others. Today, we adhere to that approach and reaffirm the approach to claim construction outlined in that case, in Markman, and in Innova."). 
in choosing and using objective reference sources in light of all the other circumstances in a case. This flexibility, however, comes at the price of the costly uncertainties now imposed all the more clearly on other patent system actors-patentees, potential licensees, accused infringers, and the Patent Office.

After Phillips, as before, dictionaries are bound to be used routinely for claim construction. After Phillips, as before, the Federal Circuit provides no rules or principles, other than "sound discretion," for how a judge should choose or use a dictionary in this context. After Phillips, as before, the Patent Office has the power to make dictionary selection more predictable, as we have explained at length. ${ }^{321}$ Nothing in Phillips stands in the way of the regulatory solution we propose. Given the benefits that would accrue from the truly objective and predictable use of objective reference sources in claim construction, the Patent Office should act to make reference source selection a necessary step in obtaining a patent.

321. See supra at notes $180-273$ and accompanying text. 


\section{APPENDIX A}

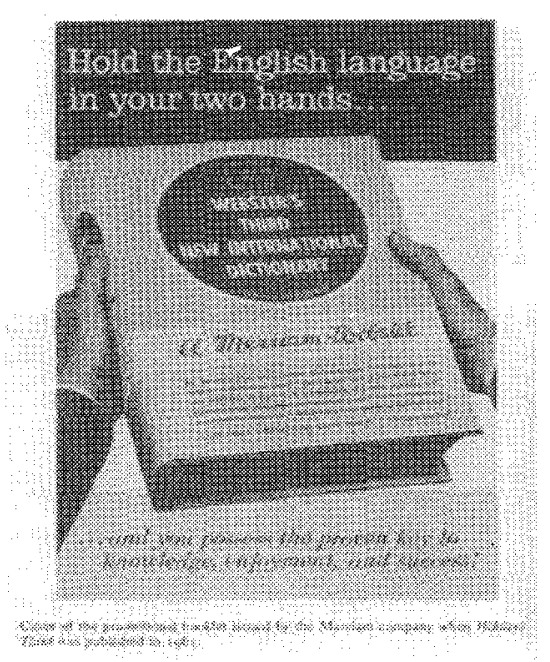

From HERBERT C. MORTON, THE STORY OF WEBSTER'S THIRD: PHILIP GOVE'S CONTROVERSIAL DICTIONARY AND ITS CRITICS 215 (1994) (facing page).

Reprinted by permission of the publisher, Merriam-Webster, Incorporated (www.Merriam-Webster.com). 


\section{APPENDIX B}

This Appendix contains all the tables and figures for this manuscript that do not fit neatly in the manuscript's main body.

\section{TABLE 5}

This table shows all the general purpose English language sources the Federal Circuit used as resources in claim construction cases from April 5, 1995, to June 30, 2004.

\begin{tabular}{|c|c|}
\hline SOURCE & CIT'N FREQUENCY $(\%)^{322}$ \\
\hline American College Dictionary (Random House) & $1(0.4 \%)$ \\
\hline American Heritage Dictionaries (Houghton Mifflin) & $24(9.0 \%)$ \\
\hline American Heritage College Dictionary ( $3 \mathrm{~d}$ ed.) & $5(1.9 \%)$ \\
\hline American Heritage Dictionary & $12(4.5 \%)$ \\
\hline American Heritage Dictionary Second College Edition & $7(2.6 \%)$ \\
\hline Chambers Concise Dictionary (Chambers) & $1(0.4 \%)$ \\
\hline Merriam-Webster Dictionaries (Merriam-Webster) & $103(38.4 \%)$ \\
\hline Merriam-Webster's New Collegiate Dictionary (10th ed.) & $3(1.1 \%)$ \\
\hline Webster's New Collegiate Dictionary (6th ed.) & $7(2.6 \%)$ \\
\hline Webster's New International Dictionary & $1(0.4 \%)$ \\
\hline Webster's New International Dictionary Second Edition & $2(0.7 \%)$ \\
\hline Webster's Ninth New Collegiate Dictionary & $18(6.7 \%)$ \\
\hline Webster's Seventh New Collegiate Dictionary & $4(1.5 \%)$ \\
\hline Webster's Third New International Dictionary & $68(25.4 \%)$ \\
\hline Oxford Dictionaries (Oxford University Press) & $18(6.7 \%)$ \\
\hline Oxford English Dictionary & $14(5.2 \%)$ \\
\hline Oxford Reference Dictionary & $1(0.4 \%)$ \\
\hline Shorter Oxford English Dictionary & $3(1.1 \%)$ \\
\hline Random House Dictionaries (Random House) & $11(4.1 \%)$ \\
\hline Random House College Dictionary & $1(0.4 \%)$ \\
\hline Random House Unabridged Dictionary & $4(1.5 \%)$ \\
\hline Random House Webster's College Dictionary & $1(0.4 \%)$ \\
\hline Random House Webster's Unabridged Dictionary & $5(1.9 \%)$ \\
\hline Strunk $\mathcal{E}^{\circ}$ White, The Elements of Style (4th ed. 2000) & $1(0.4 \%)$ \\
\hline
\end{tabular}

322. Percentages based on the total number of all dictionaries, encyclopedias, treatises, and similar sources cited, i.e., 268. 


\begin{tabular}{|l|l|}
\hline “the dictionary” $^{323}$ & $1(0.4 \%)$ \\
\hline Webster's II New College Dictionary $^{324}$ (Houghton Mifflin) & $1(0.4 \%)$ \\
\hline Webster's II New Riverside University Dictionary (Riverside ${ }^{325}$ ) & $10(3.7 \%)$ \\
\hline $\begin{array}{l}\text { Webster's Encyclopedic Unabridged Dictionary (Gramercy } \\
\text { Books) }\end{array}$ & $1(0.4 \%)$ \\
\hline Webster's New 20th Century Dictionary (Simon \& Schuster) & $2(0.7 \%)$ \\
\hline Webster's New World Dictionary (various publishers) & $15(5.6 \%)$ \\
\hline TOTAL & $189(70.5 \%)$ \\
\hline
\end{tabular}

Note: This table groups together all citations to differently dated printings of the same title (e.g., the 1966, 1968, 1971, 1986, 1993, and 2002 printings of Webster's Third New International Dictionary).

323. Tex. Instruments Inc. v. Cypress Semiconductor Corp., 90 F.3d 1558, 1564, 39 U.S.P.Q.2d (BNA) 1492, 1497 (Fed. Cir. 1996) ("Although the dictionary broadly defines 'conductor' as any substance that conducts an electrical charge, the patent itself belies such a broad construction."). Judge Lourie, who authored Tex. Instruments, most often cites to WEBSTER's II NEW RIVERSIDE UNIVERSITY DICTIONARY (Riverside Publ'g Co. 1988) and WEBSTER's NEW WORLD DictionaRY (3d ed., Simon \& Schuster 1988).

324. This is the current edition of, and the successor title to, WEBSTER'S II NEW RIVERSIDE UNIVERSITY DICTIONARY (Riverside Publ'g Co. 1994).

325. Riverside Publishing Co. has been a subsidiary of Houghton Mifflin since 1979, prior to the first publication of Webster's II New Riverside University Dictionary in 1984. RIVERSIDE PUBLISHING: A DisTINGUISHED History, at http://www.riverpub.com /about/history.html (last visited July 19, 2004) (on file with American University Law Review). Sidney Landau surmises that Houghton Mifflin may have established this dictionary, which does not include taboo sexual or scatological words, to distinguish it from the American Heritage Dictionary series, which does. LANDAU, supra note 2, 22830,443 n.15 (2d ed. 2001). 


\section{TABLE 6}

This table shows all the technical or specialized sources the Federal Circuit used as resources in claim construction cases from April 5, 1995, to June 30, 2004.

\begin{tabular}{|c|c|}
\hline SOURCE & CIT'N FREQ'Y $(\%)^{326}$ \\
\hline Annual Book of ASTM Standards (1996) & 1 \\
\hline $\begin{array}{l}\text { Maribeth Cuccinelli, The Art } \mathcal{E}^{2} \text { Science of Footwear } \\
\text { Manufacturing (1974) }\end{array}$ & 1 \\
\hline Barron's Dictionary of Insurance Terms (4th ed. 2000) & 1 \\
\hline Chambers Dictionary of Science $\mathcal{E} \mathcal{F}$ Technology (1999) & 1 \\
\hline Serway \& Faughn, College Physics (4th ed. 1995) & 1 \\
\hline Michael Busby, Demystifying ATM/ADSL (Wordware 1998) & 1 \\
\hline $\begin{array}{l}\text { Cyril M. Harris, Dictionary of Architecture } \mathcal{E}^{2} \text { Construction (2d ed. } \\
\text { 1993) }\end{array}$ & 1 \\
\hline Dictionary of Computing (4th ed. 1996) & $3(1.1 \%)$ \\
\hline Dictionary of Electronics & 1 \\
\hline Dictionary of Mechanical Engineering & 2 \\
\hline Dictionary of Microbiology E Molecular Biology (2d ed. 1987) & 1 \\
\hline Dorland's Illustrated Medical Dictionary & $4(1.5 \%)$ \\
\hline Encyclopedia of Computer Science (1976) & 1 \\
\hline Encyclopedia of Polymer Science (1965) & 1 \\
\hline Skoog et al., Fundamentals of Analytical Chemistry (7th ed. 1996) & 1 \\
\hline Benjamin Lewin, Genes $N(1990)$ & 1 \\
\hline Handbook of Chemistry $\mathcal{E}^{2}$ Physics (63d ed. 1982-83) & 1 \\
\hline $\begin{array}{l}\text { Michael \& Irene Ash, Handbook of Pharmaceutical Additives } \\
\text { (1995) }\end{array}$ & 1 \\
\hline Hawley's Condensed Chemical Dictionary & $3(1.1 \%)$ \\
\hline Henderson's Dictionary of Biological Terms (11th ed. 1995) & 1 \\
\hline IBM Dictionary of Computing (10th ed. 1994) & 2 \\
\hline Illustrated Dictionary of Electronics (3rd ed. 1985) & 2 \\
\hline $\begin{array}{l}\text { G.B. Stringfellow \& H.T. Hall, } 43 \text { Journal of Crystal Growth } 47 \\
(1978)\end{array}$ & 1 \\
\hline Knight's American Mechanical Dictionary (1876) & 1 \\
\hline $\begin{array}{l}\text { Robert C. Faber, Landis on Mechanics of Patent Claim Drafting } \\
\text { (4th ed. } 2000)\end{array}$ & I \\
\hline
\end{tabular}

326. Percentages based on the total number of all dictionaries, encyclopedias, treatises, and similar sources cited, i.e., 268. Percentage values less than one percent are omitted. 


\begin{tabular}{|c|c|}
\hline $\begin{array}{l}\text { Kenneth L. Williamson, Macroscale } \text { EO Microscale Organic } \\
\text { Experiments (2d ed., Heath 1994) }\end{array}$ & 1 \\
\hline $\begin{array}{l}\text { Marks' Standard Handbook for Mechanical Engineers (9th ed. } \\
\text { 1987) }\end{array}$ & 1 \\
\hline McGraw-Hill Dictionary of Scientific E Technical Terms & $9(3.4 \%)$ \\
\hline McGraw-Hill Electronics Dictionary (5th ed. 1994) & 1 \\
\hline McGraw-Hill Encyclopedia of Science $\mathcal{E}$ Technology (7th ed. 1992) & 1 \\
\hline A. Parish, Mechanical Engineer's Reference Book (11 th ed. 1973) & 1 \\
\hline Melloni's Illustrated Medical Dictionary (1979) & 1 \\
\hline Microsoft Computer Dictionary & $7(2.6 \%)$ \\
\hline Modern Dictionary of Electronics & $5(1.9 \%)$ \\
\hline $\begin{array}{l}\text { New IEEE Standard Dictionary of Electrical Eo Electronics Terms } \\
\text { (5th ed. 1993) }\end{array}$ & $6(2.2 \%)$ \\
\hline Louis F. Feisner, Organic Experiments (Heath 1964) & 1 \\
\hline Photonics Dictionary (2000) & 1 \\
\hline $\begin{array}{l}\text { Copper Development Association, Standards Handbook: } \\
\text { Wrought E Cast Copper and Copper Alloy Products (6th ed. 1994) }\end{array}$ & 1 \\
\hline Stedman's Medical Dictionary & $3(1.1 \%)$ \\
\hline $\begin{array}{l}\text { E. Bryan Carne, Telecommunications Primer ( } 2 \mathrm{~d} \text { ed., Prentice } \\
\text { Hall 1999) }\end{array}$ & 1 \\
\hline $\begin{array}{l}\text { Karl Drlica, Understanding DNA E Gene Cloning: A Guide for the } \\
\text { Curious (2d ed. 1992) }\end{array}$ & 1 \\
\hline $\begin{array}{l}\text { Van Nostrand Reinhold Dictionary of Information Technology (3d } \\
\text { ed. 1989) }\end{array}$ & 1 \\
\hline Hala et al., Vapour Liquid Equilibrium (2d English ed. 1967) & 1 \\
\hline Wordsworth Dictionary of Science Ẽ Technology & 1 \\
\hline TOTAL & $79(29.5 \%)$ \\
\hline
\end{tabular}

Note: This table groups together all citations to differently dated versions with the same title (e.g., the 12th and 13th editions of Hawley's Condensed Chemical Dictionary). 


\section{TABLE 7}

Number of claim terms construed by reliance on a dictionary or similar source, by Judge, by Year

\begin{tabular}{|c|c|c|c|c|c|c|c|c|c|c|c|}
\hline Judge $^{327}$ & 1995 & 1996 & 1997 & 1998 & 1999 & 2000 & 2001 & 2002 & 2003 & 2004 & Total \\
\hline $\begin{array}{c}\text { Archer }^{328} \\
(100 \%)\end{array}$ & 0 & 0 & 3 & 1 & 0 & 2 & 3 & 0 & 1 & 1 & $\begin{array}{c}11 \\
(5.3 \%)\end{array}$ \\
\hline $\begin{array}{c}\text { Bryson } \\
(100 \%)\end{array}$ & 0 & 1 & 2 & 0 & 0 & 2 & 0 & 1 & 0 & 1 & $\begin{array}{c}7 \\
(3.3 \%) \\
\end{array}$ \\
\hline $\begin{array}{l}\text { Clevenger } \\
(100 \%)\end{array}$ & 0 & 4 & 4 & 1 & 1 & 1 & 5 & 3 & 3 & 2 & $\begin{array}{c}24 \\
(11.5 \%)\end{array}$ \\
\hline $\begin{array}{l}\text { Dyk }^{329} \\
(45 \%)\end{array}$ & - & - & - & - & - & 0 & 4 & 9 & 6 & 3 & $\begin{array}{c}22 \\
(10.5 \%) \\
\end{array}$ \\
\hline $\begin{array}{c}\text { Gajarsa }^{330} \\
(75 \%)\end{array}$ & - & - & 0 & 0 & 1 & 1 & 2 & 0 & 13 & 4 & $\begin{array}{c}21 \\
(10.0 \%)\end{array}$ \\
\hline $\begin{array}{l}\text { Linn }^{331} \\
(49 \%)\end{array}$ & - & - & - & - & - & 0 & 5 & 7 & 4 & 11 & $\begin{array}{c}27 \\
(12.9 \%)\end{array}$ \\
\hline $\begin{array}{l}\text { Lourie } \\
(100 \%)\end{array}$ & 0 & 2 & 0 & 0 & 1 & 9 & 3 & 4 & 0 & 4 & $\begin{array}{c}23 \\
(11.0 \%)\end{array}$ \\
\hline $\begin{array}{l}\text { Mayer } \\
(100 \%)\end{array}$ & 0 & 0 & 0 & 0 & 1 & 0 & 0 & 0 & 0 & 0 & $\begin{array}{c}1 \\
(0.5 \%)\end{array}$ \\
\hline $\begin{array}{l}\text { Michel } \\
(100 \%)\end{array}$ & 0 & 1 & 0 & 1 & 0 & 2 & 0 & 1 & 1 & 0 & $\begin{array}{c}6 \\
(2.9 \%)\end{array}$ \\
\hline $\begin{array}{l}\text { Newman } \\
(100 \%)\end{array}$ & 1 & 0 & 0 & 0 & 0 & 0 & 0 & 0 & 1 & 0 & $\begin{array}{c}2 \\
(1.0 \%)\end{array}$ \\
\hline
\end{tabular}

327. The percentage measure beneath each judge's name states the percentage of the 110 months between April 1995 (the date of the in banc Markman decision, supra note 190) and June 2004 (the end of the study) that a judge was a member of the Federal Circuit.

328. Judge Archer took senior status on December 25, 1997. U.S. CoURT OF APPEALS FOR THE FEDERAL CIRCUIT, JUDICIAL BIOGRAPHIES, at http://www.fedcir.gov/judg bios.html (last modified Jan. 25, 2005) (on file with American University Law Review).

329. Judge Dyk entered service on June 9, 2000.

330. Judge Gajarsa entered service on Sept. 12, 1997.

331. Judge Linn entered service on Jan. 1, 2000. 


\begin{tabular}{|c|c|c|c|c|c|c|c|c|c|c|c|}
\hline $\begin{array}{l}\mathrm{Nies}^{392} \\
(15 \%)\end{array}$ & 0 & 1 & - & - & - & - & - & - & - & - & $\begin{array}{c}1 \\
(0.5 \%)\end{array}$ \\
\hline $\begin{array}{c}\text { Plager }^{\$ 33} \\
(100 \%)\end{array}$ & 2 & 0 & 1 & 0 & 0 & 0 & 0 & 0 & 0 & 0 & $\begin{array}{c}3 \\
(1.4 \%)\end{array}$ \\
\hline $\begin{array}{c}\text { Prost } \\
(30 \%)^{334} \text {. }\end{array}$ & - & - & - & - & - & - & 0 & 1 & 0 & 3 & $(4 \%)$ \\
\hline $\begin{array}{l}\text { Rader } \\
(100 \%)\end{array}$ & 0 & 2 & 2 & 0 & 0 & 3 & 6 & 5 & 7 & 1 & $\begin{array}{c}26 \\
(12.4 \%)\end{array}$ \\
\hline $\begin{array}{l}\operatorname{Rich}^{335} \\
(45 \%)\end{array}$ & 0 & 1 & 1 & 1 & 3 & - & - & - & - & - & $\begin{array}{c}6 \\
(2.9 \%)\end{array}$ \\
\hline $\begin{array}{l}\text { Schall } \\
(100 \%)\end{array}$ & 0 & 2 & 1 & 3 & 3 & 2 & 0 & 1 & 2 & 4 & $\begin{array}{c}18 \\
(8.6 \%)\end{array}$ \\
\hline $\begin{array}{c}\text { Per } \\
\text { Curiam }\end{array}$ & 0 & 0 & 0 & 2 & 0 & 1 & 0 & 0 & 4 & 0 & $\begin{array}{c}7 \\
(3.3 \%)\end{array}$ \\
\hline
\end{tabular}

Note: Biographical information on the judges can be found at www.fedcir.gov/judgbios.html. In any year in which a given judge did not serve at all on the Federal Circuit, the year is marked "-" for that judge. This table does not include data for Senior Judges Friedman or Cowen, who were on senior status when the Federal Circuit issued its en bank Markman decision and who were not the authoring judge for any of the decisions we studied.

332. Judge Nies served on the Federal Circuit from its inception in 1982 until 1996. On November 1, 1995, Judge Nies took senior status, and died while serving on August 7, 1996. Briefly, NAT'L L.J., Sept. 9, 1996, at A5.

333. Judge Plager took senior status on November 30, 2000. U.S. COURT OF APPEALS FOR THE FEDERAL CIRCUIT, JUDICIAL BIOGRAPHIES, at http://www.fedcir.gov/judg bios.html (last modified Jan. 25, 2005) (on file with American University Law Review).

334. Judge Prost entered service on Oct. 2001.

335. See Victoria Slind-Flor, Giles S. Rich Dies at 95, NAT'L L.J., June 21, 1999, at A6; Judge Giles S. Rich Succumbs to Illness (Boston Patent Law Ass'n), June 30, 1999, at 1. Judge Rich served on the Federal Circuit from its inception in 1982 until the last days of his life in 1999; he died on June 9, 1999. 


\section{APPENDIX C}

This Appendix contains the basic data from the detailed review of the Federal Circuit's claim construction cases from April 1995 to June 2004. It contains data for all the opinions in which the court used one or more dictionary definitions of a word in a patent claim to construe an element of that patent claim. Cases are listed first in year order, then alphabetically by first party name. The italicized portion of an entry in the "Claim Term" column is the text for which the court used one or more dictionary definitions. When the court relied on a dictionary definition for a cognate of the word that appeared in the patent claim, rather than or in addition to the claim word itself, the cognate is indicated in brackets.

\begin{tabular}{|c|c|c|c|c|}
\hline CASE & YEAR & $\begin{array}{l}\text { CLAIM } \\
\text { TERM }\end{array}$ & SOURCE(S) USED & JUDGE \\
\hline $\begin{array}{l}\text { National Presto Indus. } v . \\
\text { Black E Decker (U.S.) Inc., } \\
\text { Nos. 92-1388, 92-1476, } \\
1995 \text { WL 367072, at *4 } \\
\text { n.2 (Fed. Cir. June } 20 \text {, } \\
\text { 1995). }\end{array}$ & 1995 & $\begin{array}{l}\text { means on } \\
\text { said } \\
\text { housing }\end{array}$ & $\begin{array}{l}\text { Webster's Ninth New } \\
\text { Collegiate Dictionary (1981) }\end{array}$ & Newman \\
\hline $\begin{array}{l}\text { Quantum Corp. v. Rodime, } \\
\text { PLC, 65 F.3d 1577, 1581, } \\
\text { 36 U.S.P.Q.2d (BNA) } \\
1162,1166 \text { (Fed. Cir. } \\
\text { 1995). }\end{array}$ & 1995 & $\begin{array}{l}\text { at least } 600 \\
\text { tpi }\end{array}$ & $\begin{array}{l}\text { Webster's Third New } \\
\text { International Dictionary } \\
\text { (1986) }\end{array}$ & Plager \\
\hline $\begin{array}{l}\text { Quantum Corp. v. Rodime, } \\
P L C, 65 \text { F.3d 1577, } 1581 \\
\text { n.3, 36 U.S.P.Q.2d } \\
\text { (BNA) } 1162,1166 \text { n.3 } \\
\text { (Fed. Cir. 1995). }\end{array}$ & 1995 & $\begin{array}{l}\text { at least } \\
\text { approximate } \\
\text { ly } 600 \mathrm{tpi}\end{array}$ & $\begin{array}{l}\text { Webster's Third New } \\
\text { International Dictionary } \\
\text { (1986) }\end{array}$ & Plager \\
\hline $\begin{array}{l}\text { Athletic Alternatives, Inc. } \\
\text { v. Prince Mfg., Inc., } 73 \\
\text { F.3d 1573, 1579, 37 } \\
\text { U.S.P.Q.2d (BNA) 1365, } \\
1370 \text { (Fed. Cir. 1996). }\end{array}$ & 1996 & $\begin{array}{l}\text { varies } \\
\text { between }\end{array}$ & $\begin{array}{l}\text { Webster's Third New } \\
\text { International Dictionary } \\
\text { (1976) }\end{array}$ & Michel \\
\hline $\begin{array}{l}\text { Cole v. Kimberly-Clark } \\
\text { Corp., } 102 \text { F.3d 524, 531, } \\
\text { 41 U.S.P.Q.2d (BNA) } \\
1001,1006 \text { (Fed. Cir. } \\
\text { 1996). }\end{array}$ & 1996 & $\begin{array}{l}\text { perforation } \\
\text { means }\end{array}$ & $\begin{array}{l}\text { Webster's Encyclopedic } \\
\text { Unabridged Dictionary } \\
\text { (1989) }\end{array}$ & Rich \\
\hline $\begin{array}{l}\text { Dana Innovations } v . \\
\text { Speakercraft, Inc., No. 95- } \\
1472,1996 \text { WL } 748250 \text {, } \\
\text { at } * 2 \text { (Fed. Cir. Dec } 2 \text {, } \\
1996 \text { ). }\end{array}$ & 1996 & $\begin{array}{l}\text { elongate } \\
\text { bar }\end{array}$ & $\begin{array}{l}\text { Webster's Third New } \\
\text { International Dictionary } \\
\text { (1986) }\end{array}$ & Schall \\
\hline $\begin{array}{l}\text { Dana Innovations } v . \\
\text { Speakercraft, Inc., No. 95- } \\
1472,1996 \text { WL } 748250 \text {, } \\
\text { at } * 2 \text { (Fed. Cir. Dec } 2 \text {, } \\
1996 \text { ). }\end{array}$ & 1996 & $\begin{array}{l}\text { elongate } \\
\text { bar }\end{array}$ & $\begin{array}{l}\text { Webster's Third New } \\
\text { International Dictionary } \\
(1986)\end{array}$ & Schall \\
\hline
\end{tabular}




\begin{tabular}{|c|c|c|c|c|}
\hline CASE & YEAR & $\begin{array}{l}\text { ClaIM } \\
\text { TERM } \\
\end{array}$ & SOURCE(S) USED & JUDGE \\
\hline $\begin{array}{l}\text { Great N. Corp. v. Henry } \\
\text { Molded Prods., Inc., } 94 \\
\text { F.3d 1569, 1574, } 39 \\
\text { U.S.P.Q.2d (BNA) 1997, } \\
\text { 2001 (Fed. Cir. 1996). }\end{array}$ & 1996 & $\begin{array}{l}\text { greater } \\
\text { flexural } \\
\text { cushionin } \\
\text { g / [ } \\
\text { flexure }]\end{array}$ & $\begin{array}{l}\text { Webster's New International } \\
\text { Dictionary (1932) }\end{array}$ & Clevenger \\
\hline $\begin{array}{l}\text { Greenberg v. Ethicon Endo- } \\
\text { Surgery, Inc., } 91 \text { F.3d } \\
1580,1583,39 \\
\text { U.S.P.Q.2d (BNA) 1783, } \\
1786 \text { (Fed. Cir. 1996). }\end{array}$ & 1996 & $\begin{array}{l}\text { detent } \\
\text { mechanis } \\
\mathrm{m}\end{array}$ & $\begin{array}{l}\text { Random House Unabridged } \\
\text { Dictionary (2d ed. 1993); } \\
\text { Webster's Third New } \\
\text { International Dictionary } \\
\text { (1968); } \\
\text { Dictionary of Mechanical } \\
\text { Engineering (4th ed. 1996) }\end{array}$ & Bryson \\
\hline $\begin{array}{l}\text { Maxwell v. J. Baker, Inc., } \\
86 \text { F.3d 1098, 1105, } 39 \\
\text { U.S.P.Q.2d (BNA) 1001, } \\
1005 \text { (Fed. Cir. 1996). }\end{array}$ & 1996 & shoe upper & $\begin{array}{l}\text { Maribeth Cuccinelli, The } \\
\text { Ant } \mathcal{E} \text { Science of Footwear } \\
\text { Manufacturing (Norman V. } \\
\text { Germany ed., 1974) }\end{array}$ & Lourie \\
\hline $\begin{array}{l}\text { Texas Instruments, Inc. } v . \\
\text { Cypress Semiconductor } \\
\text { Corp., 90 F.3d 1558, } \\
1564,39 \text { U.S.P.Q.2d } \\
\text { (BNA) 1492, } 1497 \text { (Fed. } \\
\text { Cir. 1996). }\end{array}$ & 1996 & a conductor & "the dictionary" & Lourie \\
\hline $\begin{array}{l}\text { Yamaha Corp. v. ESS } \\
\text { Tech., Inc., No. 95-1362, } \\
\text { 1996 WL 146499, at *6 } \\
\text { (Fed. Cir. Mar. 29, } \\
\text { 1996). }\end{array}$ & 1996 & $\begin{array}{l}\text { a stored } \\
\text { waveshape } \\
\text { table }\end{array}$ & $\begin{array}{l}\text { New IEEE Standard } \\
\text { Dictionary of Electrical and } \\
\text { Electronics Terms (5th ed. } \\
1993 \text { ) }\end{array}$ & Clevenger \\
\hline $\begin{array}{l}\text { Yamaha Corp. v. ESS } \\
\text { Tech., Inc., No. 95-1362, } \\
\text { 1996 WL 146499, at *6 } \\
\text { (Fed. Cir. Mar. 29, } \\
\text { 1996). }\end{array}$ & 1996 & $\begin{array}{l}\text { a stored } \\
\text { waveshape } \\
\text { table }\end{array}$ & $\begin{array}{l}\text { New IEEE Standard } \\
\text { Dictionayy of Electrical and } \\
\text { Electronics Terms (5th ed. } \\
1993 \text { ) }\end{array}$ & Clevenger \\
\hline $\begin{array}{l}\text { Yamaha Corp. v. ESS } \\
\text { Tech., Inc., No. 95-1362, } \\
\text { 1996 WL 146499, at *6 } \\
\text { (Fed. Cir. Mar. 29, } \\
\text { 1996). }\end{array}$ & 1996 & $\begin{array}{l}\text { a stored } \\
\text { waveshape } \\
\text { table }\end{array}$ & $\begin{array}{l}\text { New IEEE Standard } \\
\text { Dictionary of Electrical and } \\
\text { Electronics Terms (5th ed. } \\
1993 \text { ) }\end{array}$ & Clevenger \\
\hline $\begin{array}{l}\text { York Prods., Inc. v. Central } \\
\text { Tractor Farm Eo Family } \\
\text { Ctr., 99 F.3d 1568, 1572- } \\
\text { 73, 40 U.S.P.Q.2d (BNA) } \\
\text { 1619, } 1622 \text { (Fed. Cir. } \\
\text { 1996). }\end{array}$ & 1996 & $\begin{array}{l}\text { a } \\
\text { substantial } \\
\text { part of } / \\
{[\text { substantia }} \\
\text { lly }]\end{array}$ & $\begin{array}{l}\text { American Heritage Dictionary } \\
\text { Second College Edition } \\
\text { (1982); } \\
\text { Webster's Ninth New } \\
\text { Collegiate Dictionary (1983) }\end{array}$ & Rader \\
\hline $\begin{array}{l}\text { York Prods., Inc. v. Central } \\
\text { Tractor Farm E' Family } \\
\text { Ctr., 99 F.3d 1568, 1575, } \\
40 \text { U.S.P.Q.2d (BNA) } \\
1619,1625 \text { (Fed. Cir. } \\
\text { 1996). }\end{array}$ & 1996 & $\begin{array}{l}\text { a plurality } \\
\text { of ... }\end{array}$ & $\begin{array}{l}\text { American Heritage Dictionary } \\
\text { Second College Edition } \\
\text { (1982) }\end{array}$ & Rader \\
\hline $\begin{array}{l}\text { Zygo Corp. v. Wyko Corp., } \\
79 \text { F.3d 1563, } 1565 \text { n.1, } \\
\text { 38 U.S.P.Q.2d (BNA) } \\
\text { 1281, } 1282 \text { n.1 (Fed. Cir. } \\
1996 \text { ). }\end{array}$ & 1996 & $\begin{array}{l}\text { coherence } \\
\text { length of } \\
\text { the beam }\end{array}$ & $\begin{array}{l}\text { Handbook of Chemistry } \mathcal{E}^{\circ} \\
\text { Physics (63d ed. 1982-83) }\end{array}$ & Nies \\
\hline
\end{tabular}




\begin{tabular}{|c|c|c|c|c|}
\hline CASE & YEAR & $\begin{array}{l}\text { CLAIM } \\
\text { TERM } \\
\end{array}$ & SOURCE(S) USED & JUDGE \\
\hline $\begin{array}{l}\text { American Permahedge, Inc. } \\
\text { v. Barcana, Inc., } 105 \text { F.3d } \\
1441,1444,41 \\
\text { U.S.P.Q.2d (BNA) 1614, } \\
1616 \text { (Fed. Cir. 1997). }\end{array}$ & 1997 & $\begin{array}{l}\text { extending } \\
\text { lateraly of }\end{array}$ & $\begin{array}{l}\text { American Heritage Dictionary } \\
\text { (2d ed. 1976) }\end{array}$ & Clevenger \\
\hline $\begin{array}{l}\text { Foster v. Hallco Mfg. Co., } \\
\text { Inc., No. } 96-1399,1997 \\
\text { WL } 419391, \text { at } * 8 \text { (Fed. } \\
\text { Cir. July 14, 1997). }\end{array}$ & 1997 & $\begin{array}{l}\text { are secured } \\
\text { to }\end{array}$ & $\begin{array}{l}\text { Webster's II New Riverside } \\
\text { University Dictionary ( } 2 \mathrm{~d} \text { ed. } \\
1988 \text { ) }\end{array}$ & Rader \\
\hline $\begin{array}{l}\text { Genentech, Inc. v. Chiron } \\
\text { Corp., } 112 \text { F.3d 495, 501, } \\
42 \text { U.S.P.Q.2d (BNA) } \\
1608,1613 \text { (Fed. Cir. } \\
\text { 1997). }\end{array}$ & 1997 & $\begin{array}{l}\text { joined in } \\
\text { proper } \\
\text { reading } \\
\text { frame }\end{array}$ & $\begin{array}{l}\text { Karl Drlica, Understanding } \\
\text { DNA and Gene Cloning: A } \\
\text { Guide for the Curious }(2 \mathrm{~d} \\
\text { ed. 1992) }\end{array}$ & Rich \\
\hline $\begin{array}{l}\text { Hazani v. United States } \\
\text { Int'l Trade Comm'n, } 126 \\
\text { F.3d 1473, 1480, } 44 \\
\text { U.S.P.Q.2d (BNA) 1358, } \\
\text { 1363-64 (Fed. Cir. 1997). }\end{array}$ & 1997 & $\begin{array}{l}\text { integrally } \\
\text { formed in }\end{array}$ & $\begin{array}{l}\text { Webster's New International } \\
\text { Dictionary (2d ed. 1939) }\end{array}$ & Bryson \\
\hline $\begin{array}{l}\text { Hazani v. U.S. Int'l Trade } \\
\text { Comm'n, 126 F.3d 1473, } \\
\text { 1480, 44 U.S.P.Q.2d } \\
\text { (BNA) 1358, 1363-64 } \\
\text { (Fed.Cir. 1997). }\end{array}$ & 1997 & $\begin{array}{l}\text { integrally } \\
\text { formed in }\end{array}$ & $\begin{array}{l}\text { Webster's New International } \\
\text { Dictionary (2d ed. 1939) }\end{array}$ & Bryson \\
\hline $\begin{array}{l}\text { In re Morris, } 127 \text { F.3d } \\
\text { 1048, 1056, 44 } \\
\text { U.S.P.Q.2d (BNA) 1023, } \\
1029 \text { (Fed. Cir. 1997). }\end{array}$ & 1997 & $\begin{array}{l}\text { integrally } \\
\text { formed as } \\
\text { a portion of }\end{array}$ & $\begin{array}{l}\text { Webster's Third New } \\
\text { International Dictionary } \\
(1986)\end{array}$ & Plager \\
\hline $\begin{array}{l}\text { Johansson v. Rose Displays } \\
\text { Ltd., No. 96-1410, } 1997 \\
\text { WL 437016, at *3 (Fed. } \\
\text { Cir. Aug. 5, 1997). }\end{array}$ & 1997 & $\begin{array}{l}\text { absent } \\
\text { deformation } \\
\text { or } \\
\text { destructio } \\
\mathrm{n} \text { of }\end{array}$ & $\begin{array}{l}\text { Webster's Third New } \\
\text { International Dictionary } \\
(1966)\end{array}$ & Clevenger \\
\hline $\begin{array}{l}\text { Johansson v. Rose Displays } \\
\text { Ltd., No. 96-1410, } 1997 \\
\text { WL } 437016 \text {, at } * 3 \text { (Fed. } \\
\text { Cir. Aug. 5, 1997). }\end{array}$ & 1997 & $\begin{array}{l}\text { absent } \\
\text { deformati } \\
\text { on or } \\
\text { destruction } \\
\text { of } \\
\end{array}$ & $\begin{array}{l}\text { Webster's Third New } \\
\text { International Dictionary } \\
\text { (1966) }\end{array}$ & Clevenger \\
\hline $\begin{array}{l}\text { Johnstown Am. Corp. v. } \\
\text { Trinity Indus., Inc., Nos. } \\
97-1070,97-1071,1997 \\
\text { WL } 291956 \text {, at } * 2 \text { (Fed. } \\
\text { Cir, May 28, 1997). }\end{array}$ & 1997 & $\begin{array}{l}\text { longitudina } \\
\text { laxis }\end{array}$ & $\begin{array}{l}\text { Cyril M. Harris, Dictionary } \\
\text { of Architecture } \mathcal{E}^{2} \\
\text { Construction ( } 2 \mathrm{~d} \text { ed. 1993) }\end{array}$ & Archer \\
\hline $\begin{array}{l}\text { Kegel Co., Inc. v. AMF } \\
\text { Bowling, Inc., } 127 \text { F.3d } \\
1420,1427,44 \\
\text { U.S.P.Q.2d (BNA) 1123, } \\
1127 \text { (Fed. Cir. 1997). }\end{array}$ & 1997 & $\begin{array}{l}\text { maintenan } \\
\text { ce assembly }\end{array}$ & $\begin{array}{l}\text { Webster's Third New } \\
\text { International Dictionary } \\
(1986)\end{array}$ & Schall \\
\hline $\begin{array}{l}\text { MHB Indus. Corp. v. } \\
\text { Garberg } \mathcal{E}^{2} \text { Assocs., Inc., } \\
\text { No. } 96-1539,1997 \text { WL } \\
423021 \text {, at } * 3 \text { (Fed. Cir. } \\
\text { July } 29,1997 \text { ). }\end{array}$ & 1997 & $\begin{array}{l}\text { across said } \\
\text { common } \\
\text { header }\end{array}$ & $\begin{array}{l}\text { Webster's Third New } \\
\text { International Dictionary } \\
(1971)\end{array}$ & Archer \\
\hline
\end{tabular}




\begin{tabular}{|c|c|c|c|c|}
\hline CASE & YEAR & $\begin{array}{l}\text { CLAIM } \\
\text { TERM }\end{array}$ & SOURCE (S) USED & JUDGE \\
\hline $\begin{array}{l}\text { MHB Indus. Corp. } v . \\
\text { Garberg E⿱ } \text { Assocs., Inc., } \\
\text { No. } 96-1539,1997 \text { WL } \\
423021 \text {, at } * 4 \text { (Fed. Cir. } \\
\text { July } 29,1997) .\end{array}$ & 1997 & bag & $\begin{array}{l}\text { Webster's Third New } \\
\text { International Dictionary } \\
\text { (1971) }\end{array}$ & Archer \\
\hline $\begin{array}{l}\text { Sage Prods., Inc. v. Devon } \\
\text { Indus., Inc., 126 F.3d } \\
1420,1430-31,44 \\
\text { U.S.P.Q.2d (BNA) 1103, } \\
1112 \text { (Fed. Cir. 1997). }\end{array}$ & 1997 & $\begin{array}{l}\text { first } \\
\text { opening } \\
\text { through }\end{array}$ & $\begin{array}{l}\text { Webster's Third Nezv } \\
\text { International Dictionary } \\
\text { (1981) }\end{array}$ & Rader \\
\hline $\begin{array}{l}\text { Young Dental Mfg. Co., } \\
\text { Inc. v. Q3 Special Prods., } \\
\text { Inc., } 112 \text { F.3d } 1137, \\
1142,42 \text { U.S.P.Q.2d } \\
\text { (BNA) 1589, } 1593 \text { (Fed. } \\
\text { Cir. 1997). }\end{array}$ & 1997 & axial bore & $\begin{array}{l}\text { Webster's Third New } \\
\text { International Dictionary } \\
\text { (1968) }\end{array}$ & Clevenger \\
\hline $\begin{array}{l}\text { Action Techs., Inc. v. } \\
\text { Novell Sys., Inc., Nos. 97- } \\
1460,97-1481,1998 \mathrm{WL} \\
279359 \text {, at } * 5 \text { (Fed. Cir. } \\
\text { May } 27,1998 \text { ). }\end{array}$ & 1998 & $\begin{array}{l}\text { type of } \\
\text { conversati } \\
\text { on }\end{array}$ & $\begin{array}{l}\text { Webster's New World } \\
\text { Dictionary ( } 3 \text { d college ed. } \\
1994 \text { ) }\end{array}$ & Schall \\
\hline $\begin{array}{l}\text { Action Techns., Inc. } v . \\
\text { Novell Sys., Inc., Nos. } 97- \\
1460,97-1481,1998 \mathrm{WL} \\
279359 \text {, at } * 6 \text { (Fed. Cir. } \\
\text { May 27, 1998). }\end{array}$ & 1998 & $\begin{array}{l}\text { state of the } \\
\text { conversati } \\
\text { on }\end{array}$ & $\begin{array}{l}\text { Webster's New World } \\
\text { Dictionary ( } 3 \mathrm{~d} \text { college ed. } \\
\text { 1994) }\end{array}$ & Schall \\
\hline $\begin{array}{l}\text { Cybor Corp. v. FAS Techs., } \\
\text { Inc., 138 F.3d 1448, } \\
\text { 1459, } 46 \text { U.S.P.Q.2d } \\
\text { (BNA) 1169, } 1177 \text { (Fed. } \\
\text { Cir. 1998). }\end{array}$ & 1998 & $\begin{array}{l}\text { through } \\
{[\mathrm{X}] \text { to }[\mathrm{Y}]}\end{array}$ & $\begin{array}{l}\text { Webster's II New Riverside } \\
\text { University Dictionary (1984) }\end{array}$ & Archer \\
\hline $\begin{array}{l}\text { Lee's Aquarium E्F Pet } \\
\text { Prods., Inc. v. Python } \\
\text { Prods., Inc., Nos. 97-1278, } \\
\text { 97-1328, 1998 WL } \\
\text { 129903, at *3 (Fed. Cir. } \\
\text { Mar. 24, 1998). }\end{array}$ & 1998 & gravel & $\begin{array}{l}\text { Annual Book of ASTM } \\
\text { Standards, American Society } \\
\text { of Testing Materials (1996); } \\
\text { Random House Webster's } \\
\text { College Dictionary (1991); } \\
\text { Webster's New World } \\
\text { Dictionary (3d college ed. } \\
\text { 1994); } \\
\text { American Heritage College } \\
\text { Dictionary (3d ed. 1997); } \\
\text { Webster's New World } \\
\text { Dictionary } \\
\end{array}$ & $\begin{array}{l}\text { Per } \\
\text { Curiam }\end{array}$ \\
\hline $\begin{array}{l}\text { Phillips Petroleum Co. v. } \\
\text { Huntsman Polymers Corp., } \\
\text { 157 F.3d 866, 874-75, } 48 \\
\text { U.S.P.Q.2d (BNA) 1161, } \\
1168 \text { (Fed. Cir. 1998). }\end{array}$ & 1998 & $\begin{array}{l}\text { block } \\
\text { copolymer }\end{array}$ & $\begin{array}{l}\text { Encyclopedia of Polymer } \\
\text { Science }(1965)\end{array}$ & $\begin{array}{l}\text { Per } \\
\text { Curiam }\end{array}$ \\
\hline $\begin{array}{l}\text { Renishaw PLC v. Marposs } \\
\text { Societa' per Azioni, } 158 \\
\text { F.3d 1243, 1251, } 1251 \\
\text { n.4, 48 U.S.P.Q.2d } \\
\text { (BNA) 1117, 1123, } 1123 \\
\text { n.4 (Fed. Cir. 1998). }\end{array}$ & 1998 & $\begin{array}{l}\text { generating } \\
\text { a trigger } \\
\text { signal when }\end{array}$ & $\begin{array}{l}\text { Webster's Ninth New } \\
\text { Collegiate Dictionary (1985); } \\
\text { Webster's Third New } \\
\text { International Dictionary } \\
(1993) ; \\
\text { Chambers Concise Dictionary } \\
(1992)\end{array}$ & Clevenger \\
\hline
\end{tabular}




\begin{tabular}{|c|c|c|c|c|}
\hline CASE & YEAR & $\begin{array}{l}\text { CLAIM } \\
\text { TERM }\end{array}$ & SOURCE (S) USED & JUDGE \\
\hline $\begin{array}{l}\text { Rockwell Int'l Corp. } v . \\
\text { United States, } 147 \text { F.3d } \\
1358,1363,1363 \text { n.7, } 47 \\
\text { U.S.P.Q.2d (BNA) 1027, } \\
\text { 1030, } 1030 \text { n.7 (Fed. Cir. } \\
\text { 1998). }\end{array}$ & 1998 & $\begin{array}{l}\text { open cold- } \\
\text { wall } \\
\text { reactor } \\
\text { [cold-wall } \\
\text { added } \\
\text { during } \\
\text { prosecutio } \\
\text { n history] }\end{array}$ & $\begin{array}{l}\text { G.B. Stringfellow \& H.T. } \\
\text { Hall, 43 J. CRYSTAL } \\
\text { GROWTH } 47 \text { (1978) }\end{array}$ & Michel \\
\hline $\begin{array}{l}\text { Technology Chems. } \mathcal{F}^{2} \\
\text { Prods., Inc. v. Home } \\
\text { Diagnostics, Inc., Nos. 97- } \\
\text { 1068, 97-1075, 1998 WL } \\
163650, \text { at *6 (Fed. Cir. } \\
\text { Apr. } 9,1998 \text { ). }\end{array}$ & 1998 & $\begin{array}{l}\text { porosity } \\
\text { gradient }\end{array}$ & $\begin{array}{l}\text { Webster's Third New } \\
\text { International Dictionary } \\
\text { (1986) }\end{array}$ & Schall \\
\hline $\begin{array}{l}\text { Trimedyne, Inc. v. Surgical } \\
\text { Laser Techs., Inc., No. } 96- \\
1538,1998 \text { WL } 393864 \text {, } \\
\text { at } * 12 \text { (Fed. Cir. July 10, } \\
1998 \text { ). }\end{array}$ & 1998 & $\begin{array}{l}\text { a hollow, } \\
\text { bulbous } \\
\text { element }\end{array}$ & $\begin{array}{l}\text { Random House Unabridged } \\
\text { Dictionary (2d ed. 1993); } \\
\text { Webster's II New Riverside } \\
\text { University Dictionary (1984) }\end{array}$ & Rich \\
\hline $\begin{array}{l}\text { Antonious v. Spalding } \mathcal{E}^{\circ} \\
\text { Evenflo Co., Inc., No. } 98- \\
1478,1999 \text { WL } 777450, \\
\text { at } * 3 \text { (Fed. Cir. Aug. } 31 \text {, } \\
\text { 1999). }\end{array}$ & 1999 & $\begin{array}{l}\text { attached } \\
\text { solely to } \\
\text { said rear } \\
\text { wall }\end{array}$ & $\begin{array}{l}\text { Webster's Third New } \\
\text { International Dictionary } \\
\text { (1971) }\end{array}$ & Schall \\
\hline $\begin{array}{l}\text { Antonious v. Spalding Eo } \\
\text { Evenflo Co., Inc., No. } 98- \\
1478,1999 \text { WL. } 777450, \\
\text { at } * 3 \text { (Fed. Cir. Aug. } 31 \text {, } \\
1999 \text { ). }\end{array}$ & 1999 & $\begin{array}{l}\text { attached } \\
\text { solely to } \\
\text { said rear } \\
\text { wall }\end{array}$ & $\begin{array}{l}\text { Webster's Third New } \\
\text { International Dictionary } \\
\text { (1971) }\end{array}$ & Schall \\
\hline $\begin{array}{l}\text { Bickerstaff v. Dr. Shrink, } \\
\text { Inc., No. 99-1091, } 1999 \\
\text { WL 693884, at *6 (Fed. } \\
\text { Cir. Sept. 3, 1999). }\end{array}$ & 1999 & cowl & $\begin{array}{l}\text { Webster's Third New } \\
\text { International Dictionary } \\
(1986)\end{array}$ & Schall \\
\hline $\begin{array}{l}\text { Karlin Tech., Inc. v. } \\
\text { Surgical Dynamics, Inc., } \\
177 \text { F.3d 968, 971, 50 } \\
\text { U.S.P.Q.2d (BNA) 1465, } \\
1468 \text { (Fed. Cir. 1999). }\end{array}$ & 1999 & $\begin{array}{l}\text { series of } \\
\text { threads }\end{array}$ & $\begin{array}{l}\text { Webster's Ninth New } \\
\text { Collegiate Dictionary (1986) }\end{array}$ & Rich \\
\hline $\begin{array}{l}\text { Karlin Tech., Inc. } v . \\
\text { Surgical Dynamics, Inc., } \\
177 \text { F.3d 968, 971, } 50 \\
\text { U.S.P.Q.2d (BNA) 1465, } \\
\text { 1468 (Fed. Cir. 1999). }\end{array}$ & 1999 & $\begin{array}{l}\text { series of } \\
\text { threads }\end{array}$ & $\begin{array}{l}\text { McGraw-Hill Dictionary of } \\
\text { Scientific and Technical } \\
\text { Terms (5th ed. 1994); } \\
\text { A. Parish, Mechanical } \\
\text { Engineer's Reference Book } \\
\text { (11th ed. 1973) }\end{array}$ & Rich \\
\hline $\begin{array}{l}\text { Middleton, Inc. } v . \\
\text { Minnesota Mining } \mathcal{E}^{2} \text { Mfg. } \\
\text { Co., No. 99-1 201, } 1999 \\
\text { WL } 1072246, \text { at } * 4 \text { (Fed. } \\
\text { Cir. Nov. 16, 1999). }\end{array}$ & 1999 & $\begin{array}{l}\text { material } \\
\text { for } \\
\text { finishing }\end{array}$ & $\begin{array}{l}\text { Webster's Ninth New } \\
\text { Collegiate Dictionary (1984) }\end{array}$ & Clevenger \\
\hline $\begin{array}{l}\text { National Recovery Techs, } \\
\text { Inc. v. Magnetic Separation } \\
\text { Sys., Inc., } 166 \text { F.3d } 1190, \\
1195,49 \text { U.S.P.Q.2d } \\
\text { (BNA) 1671, } 1675 \text { (Fed. } \\
\text { Cir. 1999). }\end{array}$ & 1999 & $\begin{array}{l}\text { selecting for } \\
\text { processing }\end{array}$ & $\begin{array}{l}\text { Webster's New World } \\
\text { Dictionary ( } 3 \mathrm{~d} \text { college ed.) }\end{array}$ & Gajarsa \\
\hline
\end{tabular}




\begin{tabular}{|c|c|c|c|c|}
\hline CASE & YEAR & $\begin{array}{l}\text { CLAIM } \\
\text { TERM }\end{array}$ & SOURCE (S) USED & JUDGE \\
\hline $\begin{array}{l}\text { Rhine v. Casio, Inc., } 183 \\
\text { F.3d 1342, 1346, 51 } \\
\text { U.S.P.Q.2d (BNA) 1377, } \\
1379 \text { (Fed. Cir. 1999). }\end{array}$ & 1999 & flashlight & $\begin{array}{l}\text { American Heritage Dictionary } \\
\text { (2d college ed. 1982) }\end{array}$ & Mayer \\
\hline $\begin{array}{l}\text { Rival Co. v. Sunbeam } \\
\text { Corp., Nos. 98-1198, 98- } \\
\text { 1199, 1999 WL 96416, at } \\
\text { *5 (Fed. Cir. Feb. 23, } \\
\text { 1999). }\end{array}$ & 1999 & $\begin{array}{l}\text { defined by } \\
\text { the base }\end{array}$ & $\begin{array}{l}\text { Webster's II New Riverside } \\
\text { University Dictionary (1988) }\end{array}$ & Lourie \\
\hline $\begin{array}{l}\text { Ultrak, Inc. v. Radio Eng'g } \\
\text { Indus., Inc., Nos. } 97- \\
1523,97-1543,1999 \mathrm{WL} \\
197173 \text {, at } * 4,52 \\
\text { U.S.P.Q.2d (BNA) 1526, } \\
1529 \text { (Fed. Cir. Apr. 8, } \\
\text { 1999). }\end{array}$ & 1999 & $\begin{array}{l}\text { lens } \\
\text { window } \\
\text { means }\end{array}$ & $\begin{array}{l}\text { American Heritage Dictionary } \\
\text { (1969) }\end{array}$ & Rich \\
\hline $\begin{array}{l}\text { Brita Wasser-Filter-Systeme } \\
\text { v. Recovery Eng'g, Inc., } \\
\text { No. } 99-1322,2000 \mathrm{WL} \\
1375170, \text { at } * 4 \text { (Fed. Cir. } \\
\text { Sept. } 21,2000 \text { ). }\end{array}$ & 2000 & sleeve & $\begin{array}{l}\text { Oxford English Dictionary } \\
\text { (2d ed. 1989) }\end{array}$ & Gajarsa \\
\hline $\begin{array}{l}\text { Cortland Line Co., Inc. v. } \\
\text { Orvis Co., Inc., } 203 \text { F.3d } \\
\text { 1351, 1356, } 53 \\
\text { U.S.P.Q.2d (BNA) 1734, } \\
1737 \text { (Fed. Cir. 2000). }\end{array}$ & 2000 & end plate & $\begin{array}{l}\text { Webster's Ninth New } \\
\text { Collegiate Dictionary (1990) }\end{array}$ & Rader \\
\hline $\begin{array}{l}\text { Doyle v. Crain Indus., Inc., } \\
\text { No. 00-1103, } 2000 \text { WL } \\
1608826, \text { at } * 4 \text { (Fed. Cir. } \\
\text { Oct. } 25,2000 \text { ). }\end{array}$ & 2000 & $\begin{array}{l}\text { at ambient } \\
\text { temperature } \\
\mathrm{s}\end{array}$ & $\begin{array}{l}\text { Hazwley's Condensed } \\
\text { Chemical Dictionary (12th } \\
\text { ed. 1993) }\end{array}$ & Lourie \\
\hline $\begin{array}{l}\text { Doyle v. Crain Indus., Inc., } \\
\text { No. 00-1103, } 2000 \text { WL } \\
1608826 \text {, at *5 (Fed. Cir. } \\
\text { Oct } 25,2000 \text { ). }\end{array}$ & 2000 & $\begin{array}{l}\text { ejecting } \\
\text { said } \\
\text { mixture }\end{array}$ & $\begin{array}{l}\text { Webster's New World } \\
\text { Dictionary ( } 3 \text { d ed. 1988) }\end{array}$ & Lourie \\
\hline $\begin{array}{l}\text { Eisenberg } v \text {. Alimed, Inc., } \\
\text { No. } 98-1317,2000 \mathrm{WL} \\
1119743, \text { at } * 3 \text { (Fed. Cir. } \\
\text { Aug. } 8,2000) \text {. }\end{array}$ & 2000 & trough & $\begin{array}{l}\text { Webster's New Collegiate } \\
\text { Dictionary (1979) }\end{array}$ & Archer \\
\hline $\begin{array}{l}\text { Eisenberg v. Alimed, Inc., } \\
\text { No. } 98-1317,2000 \mathrm{WL} \\
1119743 \text {, at *3 (Fed. Cir. } \\
\text { Aug. } 8,2000 \text { ). }\end{array}$ & 2000 & $\begin{array}{l}\text { hollow } \\
\text { section }\end{array}$ & $\begin{array}{l}\text { Webster's New Collegiate } \\
\text { Dictionary (1979) }\end{array}$ & Archer \\
\hline $\begin{array}{l}\text { Elekta Instrument S.A. v. } \\
\text { O.U.R. Scientific Int'l, Inc., } \\
\text { 214 F.3d 1302, 1307, } 54 \\
\text { U.S.P.Q.2d (BNA) 1910, } \\
1913 \text { (Fed. Cir. 2000). }\end{array}$ & 2000 & $\begin{array}{l}\text { only within } \\
\text { a zone } \\
\text { extending } \\
\text { between } \\
\text { latitudes }\end{array}$ & $\begin{array}{l}\text { Webster's New World } \\
\text { Dictionary (3d ed. 1988) }\end{array}$ & Lourie \\
\hline $\begin{array}{l}\text { Elekta Instrument S.A. } v . \\
\text { O.U.R. Scientific Int l, Inc., } \\
\text { 214 F.3d 1302, 1307, 54 } \\
\text { U.S.P.Q.2d (BNA) 1910, } \\
1913 \text { (Fed. Cir. 2000). }\end{array}$ & 2000 & $\begin{array}{l}\text { only } \\
\text { within a } \\
\text { zone } \\
\text { extending } \\
\text { between } \\
\text { latitudes } \\
\end{array}$ & $\begin{array}{l}\text { Webster's New World } \\
\text { Dictionary (3d ed. 1988) }\end{array}$ & Lourie \\
\hline
\end{tabular}




\begin{tabular}{|c|c|c|c|c|}
\hline$\overline{\text { CASE }}$ & YEAR & $\begin{array}{l}\text { CIAIM } \\
\text { TERM }\end{array}$ & SOURCE (S) USED & JUDGE \\
\hline $\begin{array}{l}\text { Elekta Instrument S.A. } v . \\
\text { O.U.R Scientific Int'l, Inc., } \\
\text { 214 F.3d 1302, 1307,54 } \\
\text { U.S.P.Q.2d (BNA) 1910, } \\
1913 \text { (Fed. Cir. 2000). }\end{array}$ & 2000 & $\begin{array}{l}\text { only } \\
\text { within a } \\
\text { zone } \\
\text { extending } \\
\text { between } \\
\text { latitudes }\end{array}$ & $\begin{array}{l}\text { Webster's New World } \\
\text { Dictionary (3d ed. 1988) }\end{array}$ & Lourie \\
\hline $\begin{array}{l}\text { Envirco Corp. v. Clestra } \\
\text { Cleanroom, Inc., } 209 \text { F.3d } \\
\text { 1360, 1365, 54 } \\
\text { U.S.P.Q.2d (BNA) 1449, } \\
1452 \text { (Fed. Cir 2000). }\end{array}$ & 2000 & $\begin{array}{l}\text { Second } \\
\text { baffle } \\
\text { means }\end{array}$ & $\begin{array}{l}\text { Webster's Ninth New } \\
\text { Collegiate Dictionary (1990) }\end{array}$ & Rader \\
\hline $\begin{array}{l}\text { Hill-Rom Co., Inc. v. } \\
\text { Kinetic Concepts, Inc., } 209 \\
\text { F.3d 1337, 1340-41, } 54 \\
\text { U.S.P.Q.2d (BNA) 1437, } \\
1440 \text { (Fed. Cir. 2000). }\end{array}$ & 2000 & cushion & $\begin{array}{l}\text { Webster's Third New } \\
\text { International Dictionary } \\
\text { (1976) }\end{array}$ & Bryson \\
\hline $\begin{array}{l}\text { In re Hyatt, } 211 \text { F.3d } \\
1367,1371,54 \\
\text { U.S.P.Q.2d (BNA) 1664, } \\
1667 \text { (Fed. Cir. 2000). }\end{array}$ & 2000 & shar $[e]$ ing & $\begin{array}{l}\text { Webster's Third New } \\
\text { International Dictionary } \\
\text { (1968) }\end{array}$ & Bryson \\
\hline $\begin{array}{l}\text { Mitek Surgical Prods., Inc. } \\
\text { v. Arthrex, Inc., Nos. 99- } \\
\text { 1004, 99-1034, 2000 WL } \\
\text { 217637, at *2 (Fed. Cir. } \\
\text { Feb. 22, 2000). }\end{array}$ & 2000 & for boring & $\begin{array}{l}\text { Webster's Third New } \\
\text { International Dictionary } \\
\text { (1971) }\end{array}$ & $\begin{array}{l}\text { Per } \\
\text { Curiam }\end{array}$ \\
\hline $\begin{array}{l}\text { Moore U.S.A., Inc. v. } \\
\text { Standard Register Co., } 229 \\
\text { F.3d 1091, 1114, } 56 \\
\text { U.S.P.Q.2d (BNA) 1225, } \\
1241 \text { (Fed. Cir. 2000). }\end{array}$ & 2000 & $\begin{array}{l}\text { extending } \\
\text { along said } \\
\text { end edges }\end{array}$ & $\begin{array}{l}\text { Webster's II New Riverside } \\
\text { University Dictionary (1984) }\end{array}$ & Michel \\
\hline $\begin{array}{l}\text { NFA Corp. v. Asheboro } \\
\text { Elastics Corp., No. 98- } \\
1579,2000 \text { WL } 6217 \text {, at } \\
\text { *2 (Fed. Cir. Jan. } 5 \text {, } \\
2000 \text { ). }\end{array}$ & 2000 & $\begin{array}{l}\text { intermeshi } \\
\text { ng with / } \\
\text { [ inter- ] }\end{array}$ & $\begin{array}{l}\text { American Heritage Dictionary } \\
\text { (1st ed. 1981) }\end{array}$ & Clevenger \\
\hline $\begin{array}{l}\text { Optical Disc Corp. v. Del } \\
\text { Mar Avionics, } 208 \text { F.3d } \\
\text { 1324, 1335, } 54 \\
\text { U.S.P.Q.2d (BNA) 1289, } \\
1295 \text { (Fed. Cir. 2000). }\end{array}$ & 2000 & $\begin{array}{l}\text { ramped } \\
\text { trailing } \\
\text { edges / } \\
\text { [ ramp ] }\end{array}$ & $\begin{array}{l}\text { Webster's Third New } \\
\text { International Dictionary } \\
\text { (1986); } \\
\text { Modern Dictionary of } \\
\text { Electronics (6th ed. 1997) }\end{array}$ & Schall \\
\hline $\begin{array}{l}\text { Optical Disc Corp. v. Del } \\
\text { Mar Avionics, 208 F.3d } \\
\text { 1324, 1338, 54 } \\
\text { U.S.P.Q.2d (BNA) 1289, } \\
\text { 1298 (Fed. Cir. 2000). }\end{array}$ & 2000 & $\begin{array}{l}\text { decreasing } \\
\text { the time }\end{array}$ & $\begin{array}{l}\text { Webster's Third New } \\
\text { International Dictionary } \\
\text { (1986) }\end{array}$ & Schall \\
\hline $\begin{array}{l}\text { Space Sys./Loral, Inc. } v . \\
\text { Lockheed Martin Comp., } \\
\text { Nos. 99-1255, 99-1289, } \\
2000 \text { WL 1205154, at *5 } \\
\text { (Fed. Cir. Aug. 23, } \\
\text { 2000). }\end{array}$ & 2000 & $\begin{array}{l}\text { automatical } \\
\text { ly }\end{array}$ & $\begin{array}{l}\text { Webster's II New Riverside } \\
\text { University Dictionary (1988) }\end{array}$ & Lourie \\
\hline
\end{tabular}




\begin{tabular}{|c|c|c|c|c|}
\hline CASE & YEAR & $\begin{array}{l}\text { CLAIM } \\
\text { TERM }\end{array}$ & SOURCE (S) USED & JUDGE \\
\hline $\begin{array}{l}\text { Tate Access Floors, Inc. v. } \\
\text { Maxcess Techs., Inc., } 222 \\
\text { F.3d 958, 965, 55 } \\
\text { U.S.P.Q.2d (BNA) 1513, } \\
\text { 1517 (Fed. Cir. 2000). }\end{array}$ & 2000 & $\begin{array}{l}\text { an inner } \\
\text { body } \\
\text { portion }\end{array}$ & $\begin{array}{l}\text { Webster's New World } \\
\text { Dictionary (3d ed. 1988) }\end{array}$ & Lourie \\
\hline $\begin{array}{l}\text { Tate Access Floors, Inc. } v . \\
\text { Maxcess Techs., Inc., } 222 \\
\text { F.3d 958, 967, 55 } \\
\text { U.S.P.Q.2d (BNA) 1513, } \\
\text { 1518 (Fed. Cir. 2000). }\end{array}$ & 2000 & to expose & $\begin{array}{l}\text { Webster's Neww World } \\
\text { Dictionary (3d ed. 1988) }\end{array}$ & Lourie \\
\hline $\begin{array}{l}\text { Tate Access Floors, Inc. } v . \\
\text { Maxcess Techs., Inc., } 222 \\
\text { F.3d 958, 967, 55 } \\
\text { U.S.P.Q.2d (BNA) 1513, } \\
1518 \text { (Fed. Cir. 2000). }\end{array}$ & 2000 & $\begin{array}{l}\text { integral } \\
\text { contrastin } \\
\text { g border }\end{array}$ & $\begin{array}{l}\text { Webster's New World } \\
\text { Dictionary (3d ed. 1988) }\end{array}$ & Lourie \\
\hline $\begin{array}{l}\text { Utah Med. Prods., Inc. } v . \\
\text { Clinical Innovations } \\
\text { Assocs., No. 00-1140, } \\
2000 \text { WL 1838586, at *2 } \\
\text { n.2 (Fed. Cir. Dec. 13, } \\
\text { 2000). }\end{array}$ & 2000 & $\begin{array}{l}\text { a liquid } \\
\text { column } /[ \\
\text { U-tube } \\
\text { manometer } \\
]\end{array}$ & $\begin{array}{l}\text { McGraw-Hill Dictionary of } \\
\text { Scientific and Technical } \\
\text { Terms (5th ed. 1994) }\end{array}$ & Michel \\
\hline $\begin{array}{l}\text { UN Coatings, Ltd. v. Sico, } \\
\text { Inc., No. 99-1336, } 2000 \\
\text { WL } 986965, \text { at *3 (Fed. } \\
\text { Cir. July } 18,2000 \text { ). }\end{array}$ & 2000 & sprayable & $\begin{array}{l}\text { Webster's Third New } \\
\text { International Dictionary } \\
\text { (1986) }\end{array}$ & Rader \\
\hline $\begin{array}{l}\text { Acromed Corp. v. Sofamor } \\
\text { Danek Group, Inc., } 253 \\
\text { F.3d 1371, 1381, } 59 \\
\text { U.S.P.Q.2d (BNA) } 1130 \text {, } \\
1137 \text { (Fed. Cir. 2001). }\end{array}$ & 2001 & $\begin{array}{l}\text { engag }[e] \text { in } \\
\mathrm{g}\end{array}$ & $\begin{array}{l}\text { Webster's II New Riverside } \\
\text { University Dictionary (1988) }\end{array}$ & Rader \\
\hline $\begin{array}{l}\text { Bell Atl. Network Servs., } \\
\text { Inc. v. Covad } \\
\text { Communications Group, } \\
\text { Inc., 262 F.3d } 1258, \\
1276,59 \text { U.S.P.Q.2d } \\
\text { (BNA) 1865, } 1877 \text { (Fed. } \\
\text { Cir. 2001). }\end{array}$ & 2001 & channel & $\begin{array}{l}\text { E. Bryan Carne, } \\
\text { Telecommunications Primer } \\
\text { (2d ed., Prentice Hall } \\
\text { 1999); } \\
\text { Michael Busby, } \\
\text { Demystifying } A T M / A D S L \\
\text { (Wordware 1998) }\end{array}$ & Gajarsa \\
\hline $\begin{array}{l}\text { Circle R, Inc. v. Trail King } \\
\text { Indus., Inc., } 21 \text { Fed. } \\
\text { Appx. 894, } 898 \text { (Fed. } \\
\text { Cir. 2001). }\end{array}$ & 2001 & $\begin{array}{l}\text { substantiall } \\
\text { y flat }\end{array}$ & $\begin{array}{l}\text { American Heritage Dictionary } \\
\text { Second College Edition } \\
(1982) ; \\
\text { Webster's Ninth New } \\
\text { Collegiate Dictionary (1983) }\end{array}$ & Dyk \\
\hline $\begin{array}{l}\text { Dayco Prods., Inc. v. Total } \\
\text { Containment, Inc., } 258 \\
\text { F.3d 1317, 1328, } 1328 \\
\text { n.5, 59 U.S.P.Q.2d } \\
\text { (BNA) 1489, 1497, } 1497 \\
\text { n.5 (Fed. Cir. 2001). }\end{array}$ & 2001 & $\begin{array}{l}\text { a plurality } \\
\text { of }\end{array}$ & $\begin{array}{l}\text { American Heritage Dictionary } \\
\text { Second College Edition } \\
\text { (1982); } \\
\text { Random House Webster's } \\
\text { Unabridged Dictionary (2d } \\
\text { ed. 1988) }\end{array}$ & Dyk \\
\hline $\begin{array}{l}\text { Doorking, Inc. u. Sentex } \\
\text { Sys., Inc., } 19 \text { Fed. Appx. } \\
\text { 872, } 876 \text { (Fed. Cir. } \\
\text { 2001). }\end{array}$ & 2001 & $\begin{array}{l}\text { disabl[ }[e] \text { in } \\
\text { g said }[\mathrm{X}]\end{array}$ & $\begin{array}{l}\text { Webster's Third New } \\
\text { International Dictionary } \\
\text { (1968) }\end{array}$ & Dyk \\
\hline
\end{tabular}




\begin{tabular}{|c|c|c|c|c|}
\hline CASE & YEAR & $\begin{array}{l}\text { CLAIM } \\
\text { TERM }\end{array}$ & SOURCE(S) USED & JUDGE \\
\hline $\begin{array}{l}\text { Dow Chem. Co. v. } \\
\text { Sumitomo Chem. Co., } 257 \\
\text { F.3d 1364, 1373, } 1373 \\
\text { n.8, 1374, 1374 n.9, } \\
\text { 1375-76, 59 U.S.P.Q.2d } \\
\text { (BNA) } 1609,1615,1615 \\
\text { n.89, } 1616 \text { (Fed. Cir. } \\
\text { 2001). }\end{array}$ & 2001 & $\begin{array}{l}\text { codistills .. } \\
\text { at a } \\
\text { boiling } \\
\text { point/ } \\
{[\text { distillatio }} \\
n]\end{array}$ & $\begin{array}{l}\text { Hazwley's Condensed } \\
\text { Chemical Dictionary (13th } \\
\text { ed. 1997); } \\
\text { Louis F. Feisner, Organic } \\
\text { Experiments (Heath 1964); } \\
\text { Kenneth L. Williamson, } \\
\text { Macroscale and Microscale } \\
\text { Organic Experiments (2d } \\
\text { ed., Heath 1994); } \\
\text { Hala et al., Vapour Liquid } \\
\text { Equilibrium (2d English ed. } \\
\text { 1967) }\end{array}$ & Gajarsa \\
\hline $\begin{array}{l}\text { Durel Corp. v. Osram } \\
\text { Sylvania Inc., 256 F.3d } \\
1298,1304,59 \\
\text { U.S.P.Q.2d (BNA) 1238, } \\
1242 \text { (Fed. Cir. 2001). }\end{array}$ & 2001 & $\begin{array}{l}\text { metal oxide } \\
\text { coating }\end{array}$ & $\begin{array}{l}\text { McGraw-Hill Dictionary of } \\
\text { Scientific and Technical } \\
\text { Terms (5th ed. 1994); } \\
\text { Hawley's Condensed } \\
\text { Chemical Dictionary (12th } \\
\text { ed. 1993) }\end{array}$ & Lourie \\
\hline $\begin{array}{l}\text { Ecolab, Inc. } v . \text { Envirochem, } \\
\text { Inc., } 264 \text { F.3d 1358, } \\
1366,60 \text { U.S.P.Q.2d } \\
\text { (BNA) 1173, } 1179 \text { (Fed. } \\
\text { Cir. 2001). }\end{array}$ & 2001 & $\begin{array}{l}\text { substantial } \\
\text { ly uniform } \\
\text { alkaline } \\
\text { detergent }\end{array}$ & $\begin{array}{l}\text { American Heritage College } \\
\text { Dictionary ( } 3 \mathrm{~d} \text { ed. 1997) }\end{array}$ & Linn \\
\hline $\begin{array}{l}\text { Ecolab, Inc. v. Envirochem, } \\
\text { Inc., 264 F.3d 1358, } \\
\text { 1366, } 60 \text { U.S.P.Q.2d } \\
\text { (BNA) 1173, } 1179 \text { (Fed. } \\
\text { Cir. 2001). }\end{array}$ & 2001 & $\begin{array}{l}\text { substantiall } \\
y \text { uniform } \\
\text { alkaline } \\
\text { detergent }\end{array}$ & $\begin{array}{l}\text { American Heritage Dictionary } \\
\text { Second College Edition } \\
\text { (1982); } \\
\text { Webster's Ninth New } \\
\text { Collegiate Dictionary (9th } \\
\text { ed. 1983) }\end{array}$ & Linn \\
\hline $\begin{array}{l}\text { Fin Control Sys. Pty, Ltd. } \\
\text { v. OAM, Inc., 265 F.3d } \\
\text { 1311, 1318, 60 } \\
\text { U.S.P.Q.2d (BNA) 1203, } \\
1208 \text { (Fed. Cir. 2001). }\end{array}$ & 2001 & lateral & $\begin{array}{l}\text { Webster's Third New } \\
\text { International Dictionary } \\
\text { (1968) }\end{array}$ & Clevenger \\
\hline $\begin{array}{l}\text { Gart v. Logitech, Inc., } 254 \\
\text { F.3d 1334, 1343, 59 } \\
\text { U.S.P.Q.2d (BNA) 1290, } \\
1296 \text { (Fed. Cir. 2001). }\end{array}$ & 2001 & $\begin{array}{l}\text { an angular } \\
\text { medial } \\
\text { surface }\end{array}$ & $\begin{array}{l}\text { Webster's New Collegiate } \\
\text { Dictionary (1975) }\end{array}$ & Linn \\
\hline $\begin{array}{l}\text { Gart v. Logitech, Inc., } 254 \\
\text { F.3d 1334, 1343, 59 } \\
\text { U.S.P.Q.2d (BNA) 1290, } \\
1296 \text { (Fed. Cir. 2001). }\end{array}$ & 2001 & $\begin{array}{l}\text { an angular } \\
\text { medial } \\
\text { surface }\end{array}$ & $\begin{array}{l}\text { Webster's New Collegiate } \\
\text { Dictionary (1975) }\end{array}$ & Linn \\
\hline $\begin{array}{l}\text { Generation II Orthotics Inc. } \\
\text { v. Medical Tech. Inc., } 263 \\
\text { F.3d 1356, 1367, 59 } \\
\text { U.S.P.Q.2d (BNA) 1919, } \\
1928 \text { (Fed. Cir. 2001). }\end{array}$ & 2001 & $\begin{array}{l}\text { controded } \\
\text { medial } \\
\text { and lateral } \\
\text { inclination }\end{array}$ & $\begin{array}{l}\text { Stedman's Medical Dictionary' } \\
\text { (27th ed. 2000) }\end{array}$ & Linn \\
\hline $\begin{array}{l}\text { Glaxo Group Ltd. } v . \\
\text { Ranbaxy Pharm., Inc., } 262 \\
\text { F.3d 1333, 1336, 59 } \\
\text { U.S.P.Q.2d (BNA) 1950, } \\
1952 \text { (Fed. Cir. 2001). }\end{array}$ & 2001 & $\begin{array}{l}\text { essentially } \\
\text { free from }\end{array}$ & $\begin{array}{l}\text { Webster's Third New } \\
\text { International Dictionary } \\
\text { (1986) }\end{array}$ & Rader \\
\hline
\end{tabular}




\begin{tabular}{|c|c|c|c|c|}
\hline CASE & YEAR & $\begin{array}{l}\text { CLAIM } \\
\text { TERM }\end{array}$ & SOURCE (S) USED & JUDGE \\
\hline $\begin{array}{l}\text { Hemphill v. McNeil-PPC, } \\
\text { Inc., } 25 \text { Fed. Appx. } 915, \\
918 \text { (Fed. Cir. 2001). }\end{array}$ & 2001 & $\begin{array}{l}\text { vaginal } \\
\text { swab }\end{array}$ & $\begin{array}{l}\text { American Heritage Dictionary } \\
\text { (3d ed. 1992); } \\
\text { Dorland's Illustrated Medical } \\
\text { Dictionary (28th ed. 1994) }\end{array}$ & Dyk \\
\hline $\begin{array}{l}\text { Kudlacek v. DBC, Inc., } 25 \\
\text { Fed. Appx. 837, 844 } \\
\text { (Fed. Cir. 2001). }\end{array}$ & 2001 & $\begin{array}{l}\text { extending } \\
\text { into each }\end{array}$ & $\begin{array}{l}\text { Webster's Ninth New } \\
\text { Collegiate Dictionary (1985) }\end{array}$ & Clevenger \\
\hline $\begin{array}{l}\text { LNP Eng'g Plastics, Inc. v. } \\
\text { Miller Waste Mills, Inc., } \\
275 \text { F.3d 1347, 1354, } 61 \\
\text { U.S.P.Q.2d (BNA) 1193, } \\
1198 \text { (Fed. Cir. 2001). }\end{array}$ & 2001 & $\begin{array}{l}\text { substantiall } \\
y \\
\text { completely } \\
\text { wetted }\end{array}$ & $\begin{array}{l}\text { Webster's Ninth New } \\
\text { Collegiate Dictionary (1983) }\end{array}$ & Rader \\
\hline $\begin{array}{l}\text { MSM Invs. Co. v. } \\
\text { Carolwood Corp., } 259 \text { F.3d } \\
\text { 1335, 1339, } 59 \\
\text { U.S.P.Q.2d (BNA) 1856, } \\
1859 \text { (Fed. Cir. 2001). }\end{array}$ & 2001 & $\begin{array}{l}\text { method of } \\
\text { feeding }\end{array}$ & $\begin{array}{l}\text { Webster's II New Riverside } \\
\text { University Dictionary (1988) }\end{array}$ & Lourie \\
\hline $\begin{array}{l}\text { Oak Tech., Inc. v. } \\
\text { International Trade } \\
\text { Comm'n, } 248 \text { F.3d 1316, } \\
\text { 1329-30, 58 U.S.P.Q.2d } \\
\text { (BNA) 1748, } 1758 \text { (Fed. } \\
\text { Cir. 2001). }\end{array}$ & 2001 & $\begin{array}{l}\text { cyclic } \\
\text { redundancy } \\
\text { checker }\end{array}$ & $\begin{array}{l}\text { Encyclopedia of Computer } \\
\text { Science (1976) }\end{array}$ & Clevenger \\
\hline $\begin{array}{l}\text { Pandrol USA v. Airboss Ry. } \\
\text { Prods., Inc., 10 Fed. } \\
\text { Appx. 837, 842, } 842 \text { n. } 1 \\
\text { (Fed. Cir. 2001). }\end{array}$ & 2001 & $\begin{array}{l}\text { adher }[e] \text { ing } \\
\text { material }\end{array}$ & $\begin{array}{l}\text { Webster's Ninth New } \\
\text { Collegiate Dictionary (1985) }\end{array}$ & Clevenger \\
\hline $\begin{array}{l}\text { Rexnord Corp. v. Laitram } \\
\text { Corp., 274 F.3d 1336, } \\
\text { 1344, 60 U.S.P.Q. 2d } \\
\text { (BNA) 1851, } 1855 \text { (Fed. } \\
\text { Gir. 2001) }\end{array}$ & 2001 & portion & $\begin{array}{l}\text { Random House Unabridged } \\
\text { Dictionary (2d ed. 1993) }\end{array}$ & Clevenger \\
\hline $\begin{array}{l}\text { Schaefer Fan Co., Inc. v. I } \\
\mathcal{F}^{2} D \text { Mfg., 265 F.3d } 1282 \\
\text { (Fed. Cir. 2001) }\end{array}$ & 2001 & rings & $\begin{array}{l}\text { Webster's Ninth New } \\
\text { Collegiate Dictionary (1998); } \\
\text { American Heritage College } \\
\text { Dictionary (3d ed. 1997) }\end{array}$ & Rader \\
\hline $\begin{array}{l}\text { Tapco Int'l Corp. v. Van } \\
\text { Mark Prods., } 18 \text { Fed. } \\
\text { Appx. 865, } 868 \text { (Fed. } \\
\text { Cir. 2001) }\end{array}$ & 2001 & $\begin{array}{l}\text { portions } \\
\text { projecting } \\
\text { outwardly } \\
\text { from }\end{array}$ & $\begin{array}{l}\text { Webster's New Collegiate } \\
\text { Dictionary (1979) }\end{array}$ & Archer \\
\hline $\begin{array}{l}\text { Tapco Int'l Corp. v. Van } \\
\text { Mark Prods., } 18 \text { Fed. } \\
\text { Appx. 865, } 868 \text { (Fed. } \\
\text { Cir. 2001) }\end{array}$ & 2001 & $\begin{array}{l}\text { portions } \\
\text { projecting } \\
\text { outwardly } \\
\text { from } \\
\end{array}$ & $\begin{array}{l}\text { Webster's New Collegiate } \\
\text { Dictionary (1979) }\end{array}$ & Archer \\
\hline $\begin{array}{l}\text { Tapco Int'l Corp. v. Van } \\
\text { Mark Prods., } 18 \text { Fed. } \\
\text { Appx. 865, } 868 \text { (Fed. } \\
\text { Cir. 2001) }\end{array}$ & 2001 & $\begin{array}{l}\text { portions } \\
\text { projecting } \\
\text { outwardly } \\
\text { from }\end{array}$ & $\begin{array}{l}\text { Webster's New Collegiate } \\
\text { Dictionary (1979) }\end{array}$ & Archer \\
\hline $\begin{array}{l}\text { Union Pac. Res. Co. } v . \\
\text { Chesapeake Energy Comp., } \\
\text { 236 F.3d 684, 692, 57 } \\
\text { U.S.P.Q.2d (BNA) 1293, } \\
\text { 1298 (Fed. Cir. 2001) }\end{array}$ & 2001 & $\begin{array}{l}\text { comparing } \\
{[\mathrm{X}] \text { to }[\mathrm{Y}]}\end{array}$ & $\begin{array}{l}\text { American Heritage College } \\
\text { Dictionary (3d ed. 1997) }\end{array}$ & Rader \\
\hline
\end{tabular}




\begin{tabular}{|c|c|c|c|c|}
\hline CASE & YEAR & $\begin{array}{l}\text { CLAIM } \\
\text { TERM } \\
\end{array}$ & SOURCE(S) USED & JUDGE \\
\hline $\begin{array}{l}\text { Wenger Mfg., Inc. } v . \\
\text { Coating Mach. Sys., Inc., } \\
\text { 239 F.3d 1225, 1232-33, } \\
57 \text { U.S.P.Q.2d (BNA) } \\
\text { 1679, 1684-85 (Fed. Cir. } \\
\text { 2001) }\end{array}$ & 2001 & $\begin{array}{l}\text { air } \\
\text { circulat }[e] \mathrm{i} \\
\mathrm{ng} \\
\text { means/[ } \\
r e-]\end{array}$ & $\begin{array}{l}\text { Webster's Neww World } \\
\text { Dictionary (3d ed. 1988) }\end{array}$ & Lourie \\
\hline $\begin{array}{l}\text { Winbond Elecs. Corp. } v . \\
\text { International Trade } \\
\text { Comm'n, } 4 \text { Fed. Appx. } \\
832,840 \text { (Fed. Cir. 2001) }\end{array}$ & 2001 & $\begin{array}{l}\text { adjacent } \\
\text { said }[\mathrm{X}]\end{array}$ & $\begin{array}{l}\text { Webster's II New Riverside } \\
\text { University Dictionary (1988) }\end{array}$ & Rader \\
\hline $\begin{array}{l}\text { Banyan Licensing, L.C. v. } \\
\text { Orthosupport Int'l, Inc., } 34 \\
\text { Fed. Appx. 696, } 698 \\
\text { (Fed. Cir. 2002) }\end{array}$ & 2002 & $\begin{array}{l}\text { defines a } \\
\text { length }\end{array}$ & $\begin{array}{l}\text { Oxford English Dictionary } \\
\text { (2d ed. 1989) }\end{array}$ & Linn \\
\hline $\begin{array}{l}\text { Beckson Marine, Inc. v. } \\
\text { NFM, Inc., 292 F.3d 718, } \\
\text { 723-24, 63 U.S.P.Q.2d } \\
\text { (BNA) 1031, } 1034 \text { (Fed. } \\
\text { Cir. 2002) }\end{array}$ & 2002 & $\begin{array}{l}\text { sloping } \\
\text { drain } \\
\text { groove }\end{array}$ & $\begin{array}{l}\text { American Heritage Dictionary } \\
\text { (4th ed. 2000); } \\
\text { Oxford English Dictionary } \\
\text { (2d ed. 1989) }\end{array}$ & Rader \\
\hline $\begin{array}{l}\text { Belden Wire E Cable Co. v. } \\
\text { Cable Design Techs. Corp., } \\
35 \text { Fed. Appx. 905, } 907 \\
\text { (Fed. Cir. 2002) }\end{array}$ & 2002 & bronze & $\begin{array}{l}\text { Copper Development } \\
\text { Association, Standards } \\
\text { Handbook: Wrought E Cast } \\
\text { Copper and Copper Alloy } \\
\text { Products (6th ed. 1994) }\end{array}$ & Lourie \\
\hline $\begin{array}{l}\text { Benetton Sportsystem USA, } \\
\text { Inc. v. First Team Sports, } \\
\text { Inc., } 38 \text { Fed. Appx. 599, } \\
605 \text { (Fed. Cir. 2002) }\end{array}$ & 2002 & toe region & $\begin{array}{l}\text { Webster's Third New } \\
\text { International Dictionary } \\
\text { (1993) }\end{array}$ & Clevenger \\
\hline $\begin{array}{l}\text { CCS Fitness, Inc. } v . \\
\text { Brunswick Corp., } 288 \text { F.3d } \\
\text { 1359, 1367, } 62 \\
\text { U.S.P.Q.2d (BNA) 1658, } \\
1663 \text { (Fed. Cir. 2002) }\end{array}$ & 2002 & $\begin{array}{l}\text { reciprocati } \\
\text { ng member }\end{array}$ & $\begin{array}{l}\text { McGraw-Hill Dictionary of } \\
\text { Scientific and Technical } \\
\text { Terms (5th ed. 1994); } \\
\text { American Heritage Dictionary } \\
\text { (3d ed. 1996) }\end{array}$ & Michel \\
\hline $\begin{array}{l}\text { Display Techs., Inc. v. Paul } \\
\text { Flum Ideas, Inc., } 60 \text { Fed. } \\
\text { Appx. 787, } 792 \text { (Fed. } \\
\text { Cir. 2002) }\end{array}$ & 2002 & aperture & $\begin{array}{l}\text { Webster's New World } \\
\text { Dictionary (3rd college ed. } \\
\text { (1994) }\end{array}$ & Schall \\
\hline $\begin{array}{l}\text { Electro Scientific Indus., } \\
\text { Inc. v. Dynamic Details, } \\
\text { Inc., } 307 \text { F.3d 1343, } \\
\text { 1349, } 64 \text { U.S.P.Q.2d } \\
\text { (BNA) 1781, } 1784 \text { (Fed. } \\
\text { Cir. 2002) }\end{array}$ & 2002 & workpiece & $\begin{array}{l}\text { Oxford English Dictionary } \\
\text { (2d ed. 1989); } \\
\text { Robert C. Faber, Landis on } \\
\text { Mechanics of Patent Claim } \\
\text { Drafting (4th ed. 2000) }\end{array}$ & Rader \\
\hline $\begin{array}{l}\text { Frank's Casing Crew } \mathcal{E}^{\circ} \\
\text { Rental Tools, Inc. v. PMR } \\
\text { Techs., Ltd., 292 F.3d } \\
\text { 1363, 1374 \& n.8, } 63 \\
\text { U.S.P.Q.2d (BNA) 1065, } \\
1073 \text { \& n. } 8 \text { (Fed. Cir. } \\
\text { 2002) }\end{array}$ & 2002 & $\begin{array}{l}\text { monitoring } \\
\text { the torque }\end{array}$ & $\begin{array}{l}\text { Random House Webster's } \\
\text { Unabridged Dictionary (2d } \\
\text { ed. 1998); } \\
\text { Webster's Ninth New } \\
\text { Collegiate Dictionary (9th } \\
\text { ed. 1983) }\end{array}$ & Dyk \\
\hline $\begin{array}{l}\text { Honeywell Inc. v. Victor Co. } \\
\text { of Japan, Ltd., } 298 \text { F.3d } \\
1317,1324-25,63 \\
\text { U.S.P.Q.2d (BNA) 1904, } \\
1907-09 \text { (Fed. Cir. 2002) }\end{array}$ & 2002 & $\begin{array}{l}\text { placed } \\
\text { contiguous } \\
\text { the }[\mathrm{X}]\end{array}$ & $\begin{array}{l}\text { Webster's Third New } \\
\text { International Dictionary } \\
(1966)\end{array}$ & Bryson \\
\hline
\end{tabular}




\begin{tabular}{|c|c|c|c|c|}
\hline CASE & YEAR & $\begin{array}{l}\text { CLAIM } \\
\text { TERM }\end{array}$ & SOURCE(S) USED & JUDGE \\
\hline $\begin{array}{l}\text { In re Thrift, } 298 \text { F.3d } \\
\text { 1357, 1364, } 63 \\
\text { U.S.P.Q.2d (BNA) 2002, } \\
\text { 2006 (Fed. Cir. 2002) }\end{array}$ & 2002 & $\begin{array}{l}\text { speech } \\
\text { user agent } \\
/ \text { [ speech } \\
\text { recognition } \\
],[\text { speech } \\
\text { recognizer }]\end{array}$ & $\begin{array}{l}\text { IBM Dictionary of } \\
\text { Computing (10th ed. 1994); } \\
\text { Van Nostrand Reinhold } \\
\text { Dictionary of Information } \\
\text { Technology (3d ed. 1989) }\end{array}$ & Dyk \\
\hline $\begin{array}{l}\text { Inverness Med. Switz. } \\
\text { GmbH v. Princeton } \\
\text { Biomeditech Corp., } 309 \\
\text { F.3d 1365, } 1370 \text { \& n. 2-3, } \\
64 \text { U.S.P.Q.2d (BNA) } \\
\text { 1926, 1930 \& n. 2-3 } \\
\text { (Fed. Cir. 2002) } \\
\end{array}$ & 2002 & $\begin{array}{l}\text { mobility of } \\
\text { said }[\mathrm{X}] \text { is } \\
\text { facilitated } \\
\text { by / } \\
{[\text { mobile }]}\end{array}$ & $\begin{array}{l}\text { Webster's Third New } \\
\text { International Dictionary } \\
\text { (1968); } \\
\text { Shorter Oxford English } \\
\text { Dictionary (3d ed. 1947) }\end{array}$ & Dyk \\
\hline $\begin{array}{l}\text { Inverness Med. Switz. } \\
\text { GmbH v. Princeton } \\
\text { Biomeditech Corp., } 309 \\
\text { F.3d 1365, 1370 \& n. 4, } \\
64 \text { U.S.P.Q.2d (BNA) } \\
\text { 1926, 1930 \& n. } 4 \text { (Fed. } \\
\text { Cir. 2002) }\end{array}$ & 2002 & $\begin{array}{l}\text { mobility of } \\
\text { said }[X] \text { is } \\
\text { facilitated } \\
\text { by }\end{array}$ & $\begin{array}{l}\text { Webster's Third New } \\
\text { International Dictionary } \\
\text { (1968) }\end{array}$ & Dyk \\
\hline $\begin{array}{l}\text { Inverness Med. Switz. } \\
\text { GmbH v. Wamer Lambert } \\
\text { Co., 309 F.3d 1373, 1378, } \\
64 \text { U.S.P.Q.2d (BNA) } \\
\text { 1933, } 1936 \text { (Fed. Cir. } \\
\text { 2002) }\end{array}$ & 2002 & $\begin{array}{l}\text { onto a } \\
\text { portion }\end{array}$ & $\begin{array}{l}\text { Webster's Third New } \\
\text { International Dictionary } \\
\text { (1968); } \\
\text { Shorter Oxford English } \\
\text { Dictionary (3d ed. 1947) }\end{array}$ & Dyk \\
\hline $\begin{array}{l}\text { Inverness Med. Switz. } \\
\text { GmbH v. Warner Lambert } \\
\text { Co., 309 F.3d 1373, 1378- } \\
\text { 79, 64 U.S.P.Q.2d (BNA) } \\
\text { 1933, 1936-37 (Fed. Cir. } \\
\text { 2002) }\end{array}$ & 2002 & on said [X] & $\begin{array}{l}\text { Webster's Third New } \\
\text { International Dictionary } \\
\text { (1968); } \\
\text { Shorter Oxford English } \\
\text { Dictionary (3d ed. 1947) }\end{array}$ & Dyk \\
\hline $\begin{array}{l}\text { M-3 } \mathcal{E}^{2} \text { Assocs., Inc. } v . \\
\text { Cargo Sys., Inc., } 33 \text { Fed. } \\
\text { Appx. 513, } 515 \text { (Fed. } \\
\text { Cir. 2002) }\end{array}$ & 2002 & $\begin{array}{l}\text { restrain the } \\
\text { door }\end{array}$ & $\begin{array}{l}\text { Webster's Third New } \\
\text { International Dictionary } \\
(1968)\end{array}$ & Dyk \\
\hline $\begin{array}{l}\text { Manning v. Paradis, } 296 \\
\text { F.3d } 1098,1103 \text { \&c n. } 1 \text {, } \\
63 \text { U.S.P.Q.2d (BNA) } \\
1681,1685 \text { n. } 1 \text { (Fed. } \\
\text { Cir. 2002) }\end{array}$ & 2002 & $\begin{array}{l}\text { a method } \\
\text { of treating }\end{array}$ & $\begin{array}{l}\text { Webster's Third New } \\
\text { International Dictionary } \\
\text { (1966) }\end{array}$ & Dyk \\
\hline $\begin{array}{l}\text { Masco Corp. v. United } \\
\text { States, 303 F.3d 1316, } \\
\text { 1323-24, 64 U.S.P.Q.2d } \\
\text { (BNA) 1182, } 1186 \text { (Fed. } \\
\text { Cir. 2002) } \\
\end{array}$ & 2002 & $\begin{array}{l}\text { to drive the } \\
\text { lever }\end{array}$ & $\begin{array}{l}\text { American Heritage Dictionary } \\
\text { (3d ed. 1996); } \\
\text { McGraw-Hill Dictionary of } \\
\text { Scientific and Technical } \\
\text { Terms (5th ed. 1994) } \\
\end{array}$ & Linn \\
\hline $\begin{array}{l}\text { Masco Corp. v. United } \\
\text { States, 303 F.3d 1316, } \\
\text { 1327-28, } 64 \text { U.S.P.Q.2d } \\
\text { (BNA) 1182, } 1189 \text { (Fed. } \\
\text { Cir. 2002) }\end{array}$ & 2002 & $\begin{array}{l}\text { transmittin } \\
\text { g a force/ } \\
{[\text { transmissi }} \\
\text { on ] }\end{array}$ & $\begin{array}{l}\text { Dictionary of Mechanical } \\
\text { Engineering (3d ed. 1985); } \\
\text { Oxford English Dictionary } \\
\text { (2d ed. 1989) }\end{array}$ & Linn \\
\hline
\end{tabular}




\begin{tabular}{|c|c|c|c|c|}
\hline CASE & YEAR & $\begin{array}{l}\text { CLAIM } \\
\text { TERM }\end{array}$ & SOURCE(S) USED & JUDGE \\
\hline $\begin{array}{l}\text { Masco Corp. } v . \text { United } \\
\text { States, 303 F.3d 1316, } \\
\text { 1328, 64 U.S.P.Q.2d } \\
\text { (BNA) 1182, } 1189 \text { (Fed. } \\
\text { Cir. 2002) }\end{array}$ & 2002 & the dial & $\begin{array}{l}\text { American College Dictionary } \\
(1970)\end{array}$ & Linn \\
\hline $\begin{array}{l}\text { Middleton, Inc. } v . \\
\text { Minnesota Mining } \mathcal{E} \text { Mfg. } \\
\text { Co., } 311 \text { F.3d } 1384,1387 \text {, } \\
65 \text { U.S.P.Q.2d (BNA) } \\
1138,1140 \text { (Fed. Cir. } \\
2002 \text { ) }\end{array}$ & 2002 & $\begin{array}{l}\text { uniform } \\
\text { flexible } \\
\text { film }\end{array}$ & $\begin{array}{l}\text { Webster's Ninth New } \\
\text { Collegiate Dictionary (1985) }\end{array}$ & Rader \\
\hline $\begin{array}{l}\text { NeoMagic Corp. v. Trident } \\
\text { Microsystems, Inc., } 287 \\
\text { F.3d 1062, 1070-71, } 62 \\
\text { U.S.P.Q.2d (BNA) 1482, } \\
\text { 1487-88 (Fed Cir. 2002) }\end{array}$ & 2002 & $\begin{array}{l}\text { having a } \\
\text { coupling }\end{array}$ & $\begin{array}{l}\text { New IEFE Standard } \\
\text { Dictionary of Electrical and } \\
\text { Electronic Terms (5th ed. } \\
\text { 1993); } \\
\text { McGraw-Hill Dictionary of } \\
\text { Scientific and Technical } \\
\text { Terms (5th ed. 1994); } \\
\text { Modern Dictionary of } \\
\text { Electronics (7th ed. 1999) }\end{array}$ & Clevenger \\
\hline $\begin{array}{l}\text { Nikken USA, Inc. } v . \\
\text { Robinsons-May, Inc., } 51 \\
\text { Fed. Appx. 874, 881-81 } \\
\text { (Fed. Cir. 2002) }\end{array}$ & 2002 & $\begin{array}{l}\text { magnetic } \\
\text { polarity }\end{array}$ & $\begin{array}{l}\text { Serway \& Faughn, College } \\
\text { Physics (4th ed. 1995) }\end{array}$ & Lourie \\
\hline $\begin{array}{l}\text { Schreiber Foods, Inc. } v . \\
\text { Beatrice Cheese, Inc., } 31 \\
\text { Fed. Appx. 727, 731 } \\
\text { (Fed. Cir. 2002) }\end{array}$ & 2002 & $\begin{array}{l}\text { a } \\
\text { continuous } \\
\text { slice }\end{array}$ & $\begin{array}{l}\text { Webster's Ninth New } \\
\text { Collegiate Dictionary (1990) }\end{array}$ & Rader \\
\hline $\begin{array}{l}\text { Schreiber Foods, Inc. } v . \\
\text { Beatrice Cheese, Inc., } 31 \\
\text { Fed. Appx. 727, } 730 \\
\text { (Fed. Cir. 2002) }\end{array}$ & 2002 & folding & $\begin{array}{l}\text { Webster's Ninth New } \\
\text { Collegiate Dictionary (1990) }\end{array}$ & Rader \\
\hline $\begin{array}{l}\text { Schumer v. Laboratory } \\
\text { Computer Sys., Inc., } 308 \\
\text { F.3d 1304, 131 1, 64 } \\
\text { U.S.P.Q.2d (BNA) 1832, } \\
1838 \text { (Fed. Cir. 2002) }\end{array}$ & 2002 & or & $\begin{array}{l}\text { Webster's Third New } \\
\text { International Dictionary } \\
\text { (1967) }\end{array}$ & Dyk \\
\hline $\begin{array}{l}\text { Semitool, Inc. v. Novellus } \\
\text { Sys., Inc., 44 Fed. Appx. } \\
\text { 949, 956 (Fed. Cir. 2002) }\end{array}$ & 2002 & $\begin{array}{l}\text { wafer } \\
\text { support }\end{array}$ & $\begin{array}{l}\text { Knight's American } \\
\text { Mechanical Dictionary } \\
(1876)\end{array}$ & Lourie \\
\hline $\begin{array}{l}\text { Smith Eng'g Co., Inc. } v . \\
\text { Eisenmann Conp., } 28 \text { Fed. } \\
\text { Appx. 958, 963 (Fed. } \\
\text { Cir. 2002) }\end{array}$ & 2002 & inlet duct & $\begin{array}{l}\text { American Heritage Dictionary } \\
\text { (1981) }\end{array}$ & Clevenger \\
\hline $\begin{array}{l}\text { Texas Digital Sys., Inc. v. } \\
\text { Telegenix, Inc., } 308 \text { F.3d } \\
1193,1206,64 \\
\text { U.S.P.Q.2d (BNA) 1813, } \\
1821 \text { (Fed. Cir. 2002) }\end{array}$ & 2002 & $\begin{array}{l}\text { repeatedly } \\
\text { substantial } \\
\text { ly } \\
\text { simultaneo } \\
\text { usly } \\
\text { activating/ } \\
\text { [ activate] }\end{array}$ & $\begin{array}{l}\text { Modern Dictionary of } \\
\text { Electronics (6th ed. 1984) }\end{array}$ & Linn \\
\hline
\end{tabular}




\begin{tabular}{|c|c|c|c|c|}
\hline CASE & YEAR & $\begin{array}{l}\text { CLAIM } \\
\text { TERM }\end{array}$ & SOURCE(S) USED & JUDGE \\
\hline $\begin{array}{l}\text { Texas Digital Sys., Inc. } v . \\
\text { Telegenix, Inc., 308 F.3d } \\
1193,1209,64 \\
\text { U.S.P.Q.2d (BNA) 1813, } \\
1823 \text { (Fed. Cir. 2002) }\end{array}$ & 2002 & $\begin{array}{l}\text { display } \\
\text { areas }\end{array}$ & $\begin{array}{l}\text { Illustrated Dictionary of } \\
\text { Electronics (3d ed. 1985) }\end{array}$ & Linn \\
\hline $\begin{array}{l}\text { Texas Digital Sys., Inc. } v . \\
\text { Telegenix, Inc., 308 F.3d } \\
1193,1209,64 \\
\text { U.S.P.Q.2d (BNA) 1813, } \\
1823-24 \text { (Fed. Cir. 2002) }\end{array}$ & 2002 & $\begin{array}{l}\text { background } \\
\text { area }\end{array}$ & $\begin{array}{l}\text { Illustrated Dictionayy of } \\
\text { Electronics (3d ed. 1985) }\end{array}$ & Linn \\
\hline $\begin{array}{l}\text { Transclean Corp. } v . \\
\text { Bridgewood Servs., Inc., } \\
\text { 290 F.3d 1364, 137475, } \\
62 \text { U.S.P.Q.2d (BNA) } \\
\text { 1865, } 1872 \text { (Fed. Cir. } \\
\text { 2002) }\end{array}$ & 2002 & $\begin{array}{l}\text { exhibiting } \\
\text { resilient } \\
\text { characteris } \\
\text { tics / } \\
\text { [ resilience] }\end{array}$ & $\begin{array}{l}\text { McGrau-Hill Dictionary of } \\
\text { Scientific and Technical } \\
\text { Terms (5th ed. 1994); } \\
\text { American Heritage Dictionary } \\
\text { (3d ed. 1992) }\end{array}$ & Lourie \\
\hline $\begin{array}{l}\text { Union Cartide Chems. } \mathcal{E}^{2} \\
\text { Plastics Tech. Corp. v. Shell } \\
\text { Oil Co., 308 F.3d } 1167, \\
1177,64 \text { U.S.P.Q.2d } \\
\text { (BNA) 1545, } 1552 \text { (Fed. } \\
\text { Cir. 2002) }\end{array}$ & 2002 & $\begin{array}{l}\text { characteriza } \\
\text { ble by an } \\
\text { efficiency } \\
\text { equation/ } \\
\text { [ characteri } \\
z e]\end{array}$ & $\begin{array}{l}\text { Webster's Third New } \\
\text { International Dictionary } \\
\text { (1993) }\end{array}$ & Prost \\
\hline $\begin{array}{l}\text { Abbott Labs. v. Syntron } \\
\text { Bioresearch, Inc., } 334 \text { F.3d } \\
\text { 1343, 1350, 67 } \\
\text { U.S.P.Q.2d (BNA) 1337, } \\
1342 \text { (Fed. Cir. 2003) }\end{array}$ & 2003 & $\begin{array}{l}\text { non- } \\
\text { diffusively } \\
\text { bound }\end{array}$ & $\begin{array}{l}\text { Webster's Third New } \\
\text { International Dictionary } \\
(1968)\end{array}$ & Dyk \\
\hline $\begin{array}{l}\text { Abbott Labs. v. Syntron } \\
\text { Bioresearch, Inc., } 334 \mathrm{~F} .3 \mathrm{~d} \\
1343,1350,67 \\
\text { U.S.P.Q.2d (BNA) 1337, } \\
1342 \text { (Fed. Cir. 2003) }\end{array}$ & 2003 & $\begin{array}{l}\text { non- } \\
\text { diffusively } \\
\text { immobilized }\end{array}$ & $\begin{array}{l}\text { Webster's Third New } \\
\text { International Dictionary } \\
(1968)\end{array}$ & Dyk \\
\hline $\begin{array}{l}\text { Abbott Labs. v. Syntron } \\
\text { Bioresearch, Inc., } 334 \text { F.3d } \\
\text { 1343, 1350, 67 } \\
\text { U.S.P.Q.2d (BNA) 1337, } \\
1342 \text { (Fed. Cir. 2003) }\end{array}$ & 2003 & $\begin{array}{l}\text { non- } \\
\text { diffusively/ } \\
\text { [ diffusion } \\
\text { ] }\end{array}$ & $\begin{array}{l}\text { Webster's Third New } \\
\text { International Dictionary } \\
\text { (1968) }\end{array}$ & $\overline{\text { Dyk }}$ \\
\hline $\begin{array}{l}\text { Abbott Labs. v. Syntron } \\
\text { Bioresearch, Inc., } 334 \text { F.3d } \\
\text { 1343, 1354, } 67 \\
\text { U.S.P.Q.2d (BNA) 1337, } \\
\text { 1345 (Fed. Cir. 2003) }\end{array}$ & 2003 & analyte & $\begin{array}{l}\text { Skoog et al., Fundamentals } \\
\text { of Analytical Chemistry ( } 7 \text { th } \\
\text { ed. 1996) }\end{array}$ & Dyk \\
\hline $\begin{array}{l}\text { Altiris, Inc. v. Symantec } \\
\text { Corp., 318 F.3d 1363, } \\
\text { 1373, 65 U.S.P.Q.2d } \\
\text { (BNA) 1865, } 1872 \text { (Fed. } \\
\text { Cir. 2003) }\end{array}$ & 2003 & $\begin{array}{l}\text { boot } \\
\text { selection } \\
\text { flag }\end{array}$ & $\begin{array}{l}\text { Microsoft Press Computer } \\
\text { Dictionary (3d ed.) }\end{array}$ & Michel \\
\hline $\begin{array}{l}\text { Anchor Wall Sys., Inc. } v . \\
\text { Rockwood Retaining Walls, } \\
\text { Inc., 340 F.3d 1298, } \\
\text { 1307-08, 67 U.S.P.Q.2d } \\
\text { (BNA) 1865, 1871 (Fed. } \\
\text { Gir. 2003) }\end{array}$ & 2003 & $\begin{array}{l}\text { back } \\
\text { surface }\end{array}$ & $\begin{array}{l}\text { Webster's Third New } \\
\text { International Dictionary } \\
\text { (1993) }\end{array}$ & Gajarsa \\
\hline
\end{tabular}




\begin{tabular}{|c|c|c|c|c|}
\hline CASE & YEAR & $\begin{array}{l}\text { CLAAIM } \\
\text { TERM }\end{array}$ & SOURCE (s) USED & JUDGE \\
\hline $\begin{array}{l}\text { Anchor Wall Sys., Inc. } v . \\
\text { Rockwood Retaining Walls, } \\
\text { Inc., 340 F.3d 1298, } \\
\text { 1307-08, 67 U.S.P.Q.2d } \\
\text { (BNA) 1865, } 1871 \text { (Fed. } \\
\text { Cir. 2003) }\end{array}$ & 2003 & $\begin{array}{l}\text { back } \\
\text { surface }\end{array}$ & $\begin{array}{l}\text { Webster's Third New } \\
\text { International Dictionary } \\
\text { (1993) }\end{array}$ & Gajarsa \\
\hline $\begin{array}{l}\text { Anchor Wall Sys., Inc, } v . \\
\text { Rockwood Retaining Walls, } \\
\text { Inc., 340 F.3d 1298, } \\
\text { 1308, 67 U.S.P.Q.2d } \\
\text { (BNA) 1865, } 1872 \text { (Fed. } \\
\text { Cir, 2003) }\end{array}$ & 2003 & a protrusion & $\begin{array}{l}\text { Webster's Third New } \\
\text { International Dictionary } \\
\text { (1993) }\end{array}$ & Gajarsa \\
\hline $\begin{array}{l}\text { Anchor Wall Sys., Inc. } v . \\
\text { Rockwood Retaining Walls, } \\
\text { Inc., 340 F.3d 1298, } \\
\text { 1309, 67 U.S.P.Q.2d } \\
\text { (BNA) 1865, } 1872 \text { (Fed. } \\
\text { Cir. 2003) }\end{array}$ & 2003 & to mate & $\begin{array}{l}\text { Merriam-Webster's New } \\
\text { Collegiate Dictionary (10th } \\
\text { ed. 1998) }\end{array}$ & Gajarsa \\
\hline $\begin{array}{l}\text { Anchor Wall Sys., Inc. } v . \\
\text { Rockwood Retaining Walls, } \\
\text { Inc., 340 F.3d 1298, } \\
\text { 1311, } 67 \text { U.S.P.Q.2d } \\
\text { (BNA) 1865, } 1872 \text { (Fed. } \\
\text { Cir. 2003) }\end{array}$ & 2003 & $\begin{array}{l}\text { generally } \\
\text { parallel }\end{array}$ & $\begin{array}{l}\text { Webster's Third New } \\
\text { International Dictionary } \\
\text { (1993) }\end{array}$ & Gajarsa \\
\hline $\begin{array}{l}\text { Anchor Wall Sys., Inc. v. } \\
\text { Rockwood Retaining Walls, } \\
\text { Inc., } 340 \text { F.3d } 1298, \\
1311,67 \text { U.S.P.Q.2d } \\
\text { (BNA) 1865, } 1874 \text { (Fed. } \\
\text { Cir. 2003) }\end{array}$ & 2003 & $\begin{array}{l}\text { generally } \\
\text { parallel }\end{array}$ & $\begin{array}{l}\text { Merriam-Webster's New } \\
\text { Collegiate Dictionary (10th } \\
\text { ed. 1998) }\end{array}$ & Gajarsa \\
\hline $\begin{array}{l}\text { Apex Inc. v. Raritan } \\
\text { Computer, Inc., } 325 \text { F.3d } \\
\text { 1364, 1373, } 66 \\
\text { U.S.P.Q.2d (BNA) 1444, } \\
1451 \text { (Fed. Cir. 2003) }\end{array}$ & 2003 & circuit & $\begin{array}{l}\text { Dictionary of Computing } \\
\text { (4th ed. 1996) }\end{array}$ & Gajarsa \\
\hline $\begin{array}{l}\text { Apex Inc, v. Raritan } \\
\text { Computer, Inc., 325 F.3d } \\
\text { 1364, 1374, 66 } \\
\text { U.S.P.Q.2d (BNA) 1444, } \\
1452 \text { (Fed. Cir. 2003) }\end{array}$ & 2003 & $\begin{array}{l}\text { interface } \\
\text { circuit/ }[\text { in } \\
\text { terface }]\end{array}$ & $\begin{array}{l}\text { Dictionary of Computing } \\
\text { (4th ed. 1996); } \\
\text { Modern Dictionary of } \\
\text { Electronics ( } 7 \text { th ed. 1999) }\end{array}$ & Gajarsa \\
\hline $\begin{array}{l}\text { Apex Inc. v. Raritan } \\
\text { Computer, Inc., 325 F.3d } \\
\text { 1364, 1375, 66 } \\
\text { U.S.P.Q.2d (BNA) 1444, } \\
1453 \text { (Fed. Cir. 2003) }\end{array}$ & 2003 & $\begin{array}{l}\text { serial data } \\
\text { packet }\end{array}$ & $\begin{array}{l}\text { Microsoft Computer } \\
\text { Dictionary (4th ed. 1999) }\end{array}$ & Gajarsa \\
\hline $\begin{array}{l}\text { Apex Inc. v. Raritan } \\
\text { Computer, Inc., 325 F.3d } \\
\text { 1364, 1376, 66 } \\
\text { U.S.P.Q.2d (BNA) 1444, } \\
1453 \text { (Fed. Cir. 2003) }\end{array}$ & 2003 & overlay & $\begin{array}{l}\text { Microsoft Computer } \\
\text { Dictionary (4th ed. 1999) }\end{array}$ & Gajarsa \\
\hline $\begin{array}{l}\text { Apex Inc. v. Raritan } \\
\text { Computer, Inc., } 325 \text { F.3d } \\
\text { 1364, 1376, 66 } \\
\text { U.S.P.Q.2d (BNA) 1444, } \\
1453 \text { (Fed. Cir. 2003) }\end{array}$ & 2003 & $\begin{array}{l}\text { overlaid } \\
\text { signals } /[0 \\
\text { verlay ] }\end{array}$ & $\begin{array}{l}\text { Microsoft Computer } \\
\text { Dictionary (4th ed. 1999) }\end{array}$ & Gajarsa \\
\hline
\end{tabular}




\begin{tabular}{|c|c|c|c|c|}
\hline CASE & YEAR & $\begin{array}{l}\text { CLAIM } \\
\text { TERM }\end{array}$ & SOURCE(S) USED & JUDGE \\
\hline $\begin{array}{l}\text { Apex Inc. v. Raritan } \\
\text { Computer, Inc., 325 F.3d } \\
\text { 1364, 1376-77,66 } \\
\text { U.S.P.Q.2d (BNA) 1444, } \\
\text { 1454 (Fed. Cir. 2003) }\end{array}$ & 2003 & switch & $\begin{array}{l}\text { Microsoft Computer } \\
\text { Dictionary (4th ed. 1999) }\end{array}$ & Gajarsa \\
\hline $\begin{array}{l}\text { Arlington Indus., Inc. v. } \\
\text { Bridgeport Fittings, Inc., } \\
\text { 345 F.3d 1318, 1326, } 68 \\
\text { U.S.P.Q.2d (BNA) 1439, } \\
1444 \text { (Fed. Cir. 2003) }\end{array}$ & 2003 & $\begin{array}{l}\text { capable of } \\
\text { flexing }\end{array}$ & $\begin{array}{l}\text { Random House Unabridged } \\
\text { Dictionary ( } 2 \mathrm{~d} \text { ed. } 1993 \text { ) }\end{array}$ & Linn \\
\hline $\begin{array}{l}\text { Bell Communications } \\
\text { Research, Inc. v. Fore Sys., } \\
\text { Inc., } 62 \text { Fed. Appx. 951, } \\
959 \text { (Fed. Cir. 2003) }\end{array}$ & 2003 & $\begin{array}{l}\text { derived } \\
\text { from }\end{array}$ & $\begin{array}{l}\text { Webster's Third New } \\
\text { International Dictionary } \\
\text { (1993) }\end{array}$ & Clevenger \\
\hline $\begin{array}{l}\text { Boehringer Ingelheim } \\
\text { Vetmedica, Inc. v. Schering- } \\
\text { Plough Corp., 320 F.3d } \\
\text { 1339, 1346-47, 65 } \\
\text { U.S.P.Q.2d (BNA) 1961, } \\
\text { 1965-66 (Fed. Cir. 2003) }\end{array}$ & 2003 & isolat $[e]$ ing & $\begin{array}{l}\text { Dictionary of Microbiology } \\
\text { and Molecular Biology (2d } \\
\text { ed. 1987); } \\
\text { Random House College } \\
\text { Dictionary (1980) }\end{array}$ & Clevenger \\
\hline $\begin{array}{l}\text { Bowers v. Baystate Techs., } \\
\text { Inc., } 320 \text { F.3d 1317, } 1332 \\
\text { (Fed. Cir. 2003) }\end{array}$ & 2003 & plurality & $\begin{array}{l}\text { Oxford English Dictionary } \\
\text { (2d ed. 1989) }\end{array}$ & Rader \\
\hline $\begin{array}{l}\text { Brookhill-Wilk 1, LLCv. } \\
\text { Intuitive Surgical, Inc., } \\
\text { 326 F.3d 1215, 1221, } 66 \\
\text { U.S.P.Q.2d (BNA) 1517, } \\
\text { 1521 (Fed.Cir. 2003) }\end{array}$ & 2003 & $\begin{array}{l}\text { remote } \\
\text { location }\end{array}$ & $\begin{array}{l}\text { Webster's Third New } \\
\text { International Dictionary } \\
\text { (1993) }\end{array}$ & Linn \\
\hline $\begin{array}{l}\text { Deere } \mathcal{E}^{2} \text { Co. v. Toro Co., } \\
57 \text { Fed. Appx. 442, } 447 \\
\text { (Fed. Cir. 2003) }\end{array}$ & 2003 & $\begin{array}{l}\text { pivotably } \\
\text { attached }\end{array}$ & $\begin{array}{l}\text { Webster's Third New } \\
\text { International Dictionary } \\
\text { (1986) }\end{array}$ & Schall \\
\hline $\begin{array}{l}\text { Deering Precision } \\
\text { Instruments, LLC. v. Vector } \\
\text { Distribution Sys., Inc. } 347 \\
\text { F.3d 1314, 1323, } 68 \\
\text { U.S.P.Q.2d (BNA) 1716, } \\
1722 \text { (Fed. Cir. 2003) }\end{array}$ & 2003 & $\begin{array}{l}\text { substantiall } \\
y \text { in }[X]\end{array}$ & $\begin{array}{l}\text { Webster's New 20th Century } \\
\text { Dictionary (1983) }\end{array}$ & Gajarsa \\
\hline $\begin{array}{l}\text { E-Pass Techs., Inc. } v .3 \text { Com } \\
\text { Corp., 343 F.3d 1364, } \\
\text { 1367, 67 U.S.P.Q.2d } \\
\text { (BNA) 1947, } 1949 \text { (Fed. } \\
\text { Cir. 2003) }\end{array}$ & 2003 & $\begin{array}{l}\text { electronic } \\
\text { multi- } \\
\text { function } \\
\text { card }\end{array}$ & $\begin{array}{l}\text { Merriam-Webster's New } \\
\text { Collegiate Dictionary (10th } \\
\text { ed. 1999); } \\
\text { Random House Webster's } \\
\text { Unabridged Dictionary (2d } \\
\text { ed. 1998); } \\
\text { Oxford English Dictionary } \\
\text { (2d ed. 1989) }\end{array}$ & Dyk \\
\hline $\begin{array}{l}\text { Ferguson Beauregard/Logic } \\
\text { Controls, Inc. v. Mega Sys. } \\
\text { LLC, 350 F.3d 1327, } \\
\text { 1339, 69 U.S.P.Q.2d } \\
\text { (BNA) 1001, } 1009 \text { (Fed. } \\
\text { Cir. 2003) }\end{array}$ & 2003 & $\begin{array}{l}\text { normal } \\
\text { plunger } \\
\text { performan } \\
\text { ce }\end{array}$ & $\begin{array}{l}\text { Webster's Third New } \\
\text { International Dictionary } \\
\text { (1966) }\end{array}$ & Linn \\
\hline
\end{tabular}




\begin{tabular}{|c|c|c|c|c|}
\hline CASE & YEAR & $\begin{array}{l}\text { CLAIM } \\
\text { TERM }\end{array}$ & SOURCE(S) USED & JUDGE \\
\hline $\begin{array}{l}\text { Ferguson Beauregard/Logic } \\
\text { Controls, Inc. v. Mega Sys. } \\
L L C, 350 \text { F.3d } 1327, \\
1340,69 \text { U.S.P.Q.2d } \\
\text { (BNA) 1001, } 1010 \text { (Fed. } \\
\text { Cir. 2003) }\end{array}$ & 2003 & $\begin{array}{l}\text { predetermin } \\
\text { ed plunger } \\
\text { performan } \\
\text { ce }\end{array}$ & $\begin{array}{l}\text { Webster's Third New } \\
\text { International Dictionary } \\
\text { (1966) }\end{array}$ & Linn \\
\hline $\begin{array}{l}\text { Genzyme Corp. } v . \\
\text { Transkaryotic Therapies, } \\
\text { Inc., 346 F.3d 1094, } \\
\text { 1098, 68 U.S.P.Q.2d } \\
\text { (BNA) 1596, } 1599 \text { (Fed. } \\
\text { Cir. 2003) }\end{array}$ & 2003 & $\begin{array}{l}\text { chromoso } \\
\text { mally } \\
\text { integrated } \\
/[\text { integrati } \\
\text { on }]\end{array}$ & $\begin{array}{l}\text { Benjamin Lewin, Genes IV } \\
(1990)\end{array}$ & Rader \\
\hline $\begin{array}{l}\text { Glaxo Wellcome, Inc. v. } \\
\text { Andrx Pharms., Inc., } 344 \\
\text { F.3d 1226, 1229, } 68 \\
\text { U.S.P.Q.2d (BNA) 1302, } \\
\text { 1304 (Fed. Cir. 2003) }\end{array}$ & 2003 & $\begin{array}{l}\text { hydroxyprop } \\
y l \\
\text { methylcellul } \\
\text { ose }\end{array}$ & $\begin{array}{l}\text { Michael Ash \& Irene Ash, } \\
\text { Handbook of Pharmaceutical } \\
\text { Additives (1995) }\end{array}$ & Newman \\
\hline $\begin{array}{l}\text { Intellectual Prop. Dev., Inc. } \\
\text { v. UA-Columbia } \\
\text { Cablevision, Inc., } 336 \text { F.3d } \\
1308,1315-16,1316 \text { n. } 7 \text {, } \\
67 \text { U.S.P.Q.2d (BNA) } \\
\text { 1385, 1390 \& n. } 7 \text { (Fed. } \\
\text { Cir. 2003) }\end{array}$ & 2003 & $\begin{array}{l}\text { high } \\
\text { frequency } \\
\text { carrier }\end{array}$ & $\begin{array}{l}\text { McGraw-Hill Dictionary of } \\
\text { Scientific and Technical } \\
\text { Terms (1974); } \\
\text { Webster's Seventh New } \\
\text { Collegiate Dictionary (1967); } \\
\text { Oxford English Dictionary; } \\
\text { Dictionary of Electronics }\end{array}$ & Schall \\
\hline $\begin{array}{l}\text { Libman Co. v. Quickie } \\
\text { Mfg. Co., } 74 \text { Fed. Appx. } \\
900,904 \text { (Fed. Cir. 2003) }\end{array}$ & 2003 & $\begin{array}{l}\text { surround } \\
\text { the }[\mathrm{X}]\end{array}$ & $\begin{array}{l}\text { Webster's II New College } \\
\text { Dictionary (1995) }\end{array}$ & Rader \\
\hline $\begin{array}{l}\text { Moba, B.V. v. Diamond } \\
\text { Automation Inc., } 325 \text { F.3d } \\
\text { 1306, 1315, } 66 \\
\text { U.S.P.Q.2d (BNA) 1429, } \\
1435 \text { (Fed.Cir. 2003) }\end{array}$ & 2003 & $\begin{array}{l}\text { holding } \\
\text { stations / } \\
{[\text { to hold }]}\end{array}$ & $\begin{array}{l}\text { Oxford English Dictionary } \\
\text { (2d ed. 1989) }\end{array}$ & $\begin{array}{l}\text { Per } \\
\text { Curiam }\end{array}$ \\
\hline $\begin{array}{l}\text { Moba, B.V. v. Diamond } \\
\text { Automation Inc., } 325 \text { F.3d } \\
\text { 1306, 1316-17, } 66 \\
\text { U.S.P.Q.2d (BNA) 1429, } \\
\text { 1436 (Fed. Cir. 2003) }\end{array}$ & 2003 & $\begin{array}{l}\text { to urge the } \\
{[\mathrm{X}]}\end{array}$ & $\begin{array}{l}\text { Oxford English Dictionary } \\
\text { (2d ed. 1989) }\end{array}$ & $\begin{array}{l}\text { Per } \\
\text { Curiam }\end{array}$ \\
\hline $\begin{array}{l}\text { Nautilus Group, Inc. } v . \\
\text { Icon Health E Fitness, } \\
\text { Inc., } 82 \text { Fed. Appx. 691, } \\
\text { 692-93 (Fed. Cir. 2003) }\end{array}$ & 2003 & $\begin{array}{l}\text { in } \\
\text { cantilevered } \\
\text { fashion }\end{array}$ & $\begin{array}{l}\text { American Heritage Dictionary } \\
\text { Second College Edition } \\
\text { (1986); } \\
\text { McGraw-Hill Dictionary of } \\
\text { Scientific and Technical } \\
\text { Terms (3d ed. 1984); } \\
\text { Webster's Ninth New } \\
\text { Collegiate Dictionary (1986); } \\
\text { Wordsworth Dictionayy of } \\
\text { Science and Technology } \\
\text { (1995); } \\
\text { Marks'Standard Handbook } \\
\text { for Mechanical Engineers } \\
\text { (9th ed. 1987); } \\
\text { McGraw-Hill Encyclopedia of } \\
\text { Science and Technology (7th } \\
\text { ed. 1992) }\end{array}$ & Rader \\
\hline
\end{tabular}




\begin{tabular}{|c|c|c|c|c|}
\hline CASE & YEAR & $\begin{array}{l}\text { ClaAM } \\
\text { TERM }\end{array}$ & SOURCE (S) USED & JUDGE \\
\hline $\begin{array}{l}\text { Omega Eng'g, Inc. } v . \\
\text { Raytek Corp., 334 F.3d } \\
\text { 1314, 1322, 67 } \\
\text { U.S.P.Q.2d (BNA) 1321, } \\
1326 \text { (Fed. Cir. 2003) }\end{array}$ & 2003 & $\begin{array}{l}\text { the } \\
\text { periphery }\end{array}$ & $\begin{array}{l}\text { Webster's Third New } \\
\text { International Dictionary } \\
\text { (1993) }\end{array}$ & Clevenger \\
\hline $\begin{array}{l}\text { Pieczenik v. Dyax Corp., } 76 \\
\text { Fed. Appx. 293, 296-97, } \\
297 \text { n.4 (Fed. Cir. 2003) }\end{array}$ & 2003 & $\begin{array}{l}\text { oligonucleot } \\
\text { ide }\end{array}$ & $\begin{array}{l}\text { Melloni's Illustrated Medical } \\
\text { Dictionary (1979); } \\
\text { Dorland's Illustrated Medical } \\
\text { Dictionary (26th ed. 1981); } \\
\text { Stedman's Medical Dictionary } \\
\text { (24th ed. 1982); } \\
\text { Stedman's Medical Dictionary } \\
\text { (26th ed. 1995) }\end{array}$ & Rader \\
\hline $\begin{array}{l}\text { Pinnacle Pigging Sys., Inc. } \\
\text { v. Eliminator Pigging Sys. } \\
\text { USA, Inc., } 55 \text { Fed. Appx. } \\
\text { 943, 944-45 (Fed. Cir. } \\
\text { 2003) }\end{array}$ & 2003 & $\begin{array}{l}\text { after } \\
\text { inflat }[e] \text { ion } \\
\text { of }\end{array}$ & $\begin{array}{l}\text { Webster's Third New } \\
\text { International Dictionary } \\
\text { (1968) }\end{array}$ & $\begin{array}{l}\text { Per } \\
\text { Curiam }\end{array}$ \\
\hline $\begin{array}{l}\text { Rambus Inc. v. Infineon } \\
\text { Techs. Ag, } 318 \text { F.3d 1081, } \\
\text { 1091, 65 U.S.P.Q.2d } \\
\text { (BNA) 1705, } 1711 \text { (Fed. } \\
\text { Gir. 2003) }\end{array}$ & 2003 & $\begin{array}{l}\text { integrated } \\
\text { circuit } \\
\text { device }\end{array}$ & $\begin{array}{l}\text { New IEEE Standard } \\
\text { Dictionary of Electrical and } \\
\text { Electronic Terms (5th ed. } \\
\text { 1993); } \\
\text { IBM Dictionary of } \\
\text { Computing (10th ed. 1994) }\end{array}$ & Rader \\
\hline $\begin{array}{l}\text { Rambus Inc. v. Infineon } \\
\text { Techs. Ag, 318 F.3d 1081, } \\
\text { 1094, 65 U.S.P.Q.2d } \\
\text { (BNA) 1705, 1713-14 } \\
\text { (Fed. Cir. 2003) }\end{array}$ & 2003 & bus & $\begin{array}{l}\text { New IEEE Standard } \\
\text { Dictionary of Electrical and } \\
\text { Electronic Terms (5th ed. } \\
1993 \text { ) }\end{array}$ & Rader \\
\hline $\begin{array}{l}\text { Simmons, Inc. } v . \\
\text { Bombardier, Inc., } 73 \text { Fed. } \\
\text { Appx. 421, } 423 \text { (Fed. } \\
\text { Cir. 2003) }\end{array}$ & 2003 & $\begin{array}{l}\text { a bottom for } \\
{[\mathrm{X}]}\end{array}$ & $\begin{array}{l}\text { American Heritage College } \\
\text { Dictionary (3d ed. 1993) }\end{array}$ & $\begin{array}{l}\text { Per } \\
\text { Curiam }\end{array}$ \\
\hline $\begin{array}{l}\text { System Div., Inc. v. Teknek } \\
\text { LLC, } 59 \text { Fed. Appx. 333, } \\
\text { 339-40 (Fed. Cir. 2003) }\end{array}$ & 2003 & $\begin{array}{l}\text { permitting } \\
\text { ready } \\
\text { removal }\end{array}$ & $\begin{array}{l}\text { Webster's Third New } \\
\text { International Dictionary } \\
\text { (1968); } \\
\text { Random House Webster's } \\
\text { Unabridged Dictionary (2d } \\
\text { ed. 1998) }\end{array}$ & Dyk \\
\hline $\begin{array}{l}\text { Waner v. Ford Motor Co., } \\
\text { 331 F.3d 851, 854, } 66 \\
\text { U.S.P.Q.2d (BNA) 1943, } \\
\text { 1946 (Fed. Cir. 2003) }\end{array}$ & 2003 & $\begin{array}{l}\text { inboard } \\
\text { side flange }\end{array}$ & $\begin{array}{l}\text { Webster's New 20th Century } \\
\text { Dictionary (2d ed. 1962) }\end{array}$ & Archer \\
\hline $\begin{array}{l}\text { Animatics Corp. } v . \\
\text { Quicksilver Controls, Inc., } \\
102 \text { Fed. Appx. 659, } 665 \\
\text { (Fed. Cir. 2004) }\end{array}$ & 2004 & $\begin{array}{l}\text { modular } \\
\text { motor } \\
\text { body }\end{array}$ & $\begin{array}{l}\text { Webster's Seventh New } \\
\text { Collegiate Dictionary (1976) }\end{array}$ & Schall \\
\hline $\begin{array}{l}\text { Animatics Corp. } v . \\
\text { Quicksilver Controls, Inc., } \\
102 \text { Fed. Appx. 659, 662, } \\
664-65 \text { (Fed. Cir. 2004) }\end{array}$ & 2004 & $\begin{array}{l}\text { modular } \\
\text { control } \\
\text { unit }\end{array}$ & $\begin{array}{l}\text { Webster's Seventh New } \\
\text { Collegiate Dictionary (1976) }\end{array}$ & Schall \\
\hline $\begin{array}{l}\text { Animatics Corp. } v . \\
\text { Quicksilver Controls, Inc., } \\
102 \text { Fed. Appx. 659, 665- } \\
67 \text { (Fed. Cir. 2004) }\end{array}$ & 2004 & $\begin{array}{l}\text { connected } \\
\text { to }\end{array}$ & $\begin{array}{l}\text { Webster's Seventh New } \\
\text { Collegiate Dictionary (1976) }\end{array}$ & Schall \\
\hline
\end{tabular}




\begin{tabular}{|c|c|c|c|c|}
\hline CASE & YEAR & $\begin{array}{l}\text { CLAIM } \\
\text { TERM }\end{array}$ & SOURCE(S) USED & JUDGE \\
\hline $\begin{array}{l}\text { Bancorp Servs., L.L.C. v. } \\
\text { Hartford Life Ins. Co., } 359 \\
\text { F.3d 1367, 1372, 69 } \\
\text { U.S.P.Q.2d (BNA) 1996, } \\
1999 \text { (Fed. Cir. 2004) }\end{array}$ & 2004 & $\begin{array}{l}\text { surrender } \\
\text { value } \\
\text { protected } \\
\text { investment } \\
\text { credits } \\
\end{array}$ & $\begin{array}{l}\text { Barron's Dictionayy of } \\
\text { Insurance Terms ( } 4 \text { th ed. } \\
2000 \text { ) }\end{array}$ & Bryson \\
\hline $\begin{array}{l}\text { Edwards Sys. Tech., Inc. v. } \\
\text { Digital Control Sys., Inc., } \\
99 \text { Fed. Appx. 91 1, } 912- \\
13 \text { (Fed. Cir. May 18, } \\
\text { 2004) }\end{array}$ & 2004 & $\begin{array}{l}\text { specularly- } \\
\text { reflective } \\
\text { surface / [ } \\
\text { specular } \\
\text { reflection], } \\
\text { [ specular } \\
\text { reflector ] }\end{array}$ & Photonics Dictionary (2000) & Archer \\
\hline $\begin{array}{l}\text { Globetrotter Software, Inc. } \\
\text { v. Elan Computer Group, } \\
\text { Inc., } 362 \text { F.3d 1367, } \\
\text { 1380, } 70 \text { U.S.P.Q.2d } \\
\text { (BNA) 1161, } 1171 \text { (Fed. } \\
\text { Cir. 2004) }\end{array}$ & 2004 & $\begin{array}{l}\text { a message } \\
\text { preventing } \\
\text { said copy }\end{array}$ & $\begin{array}{l}\text { Random House Webster's } \\
\text { Unabridged Dictionary (2d } \\
\text { ed. 1998); } \\
\text { Webster's Third New } \\
\text { International Dictionary } \\
(2002)\end{array}$ & Dyk \\
\hline $\begin{array}{l}\text { Goldenberg v. Cytogen, } \\
\text { Inc., } 373 \text { F.3d } 1158, \\
1165,71 \text { U.S.P.Q.2d } \\
\text { (BNA) 1255, } 1260 \text { (Fed. } \\
\text { Cir. 2004) }\end{array}$ & 2004 & beta-subunit & $\begin{array}{l}\text { Dorland's Illustrated Medical } \\
\text { Dictionary (29th ed. 2000) }\end{array}$ & Gajarsa \\
\hline $\begin{array}{l}\text { Goldenberg } v . \text { Cytogen, } \\
\text { Inc., 373 F.3d 1158, } \\
\text { 1165-66, 71 U.S.P.Q.2d } \\
\text { (BNA) 1255, } 1261 \text { (Fed. } \\
\text { Cir. 2004) }\end{array}$ & 2004 & $\begin{array}{l}\text { intracellula } \\
r \text { marker } \\
\text { substance }\end{array}$ & $\begin{array}{l}\text { Dorland's Illustrated Medical } \\
\text { Dictionary (29th ed. 2000) }\end{array}$ & Gajarsa \\
\hline $\begin{array}{l}\text { Housey Pharms., Inc. } v . \\
\text { AstraZeneca UK Ltd., } 366 \\
\text { F.3d 1348, 1353, 70 } \\
\text { U.S.P.Q.2d (BNA) 1641, } \\
1645 \text { (Fed. Cir. 2004) }\end{array}$ & 2004 & $\begin{array}{l}\text { an } \\
\text { inhibitor } \\
\text { or activator } \\
\text { of a } \\
\text { protein }\end{array}$ & $\begin{array}{l}\text { Chambers Dictionary of } \\
\text { Science and Technology } \\
\text { (1999) }\end{array}$ & Clevenger \\
\hline $\begin{array}{l}\text { Housey Pharms., Inc. } v . \\
\text { AstraZeneca UK Ltd., } 366 \\
\text { F.3d 1348, 1353, 70 } \\
\text { U.S.P.Q.2d (BNA) 1641, } \\
1645 \text { (Fed. Gir. 2004) }\end{array}$ & 2004 & $\begin{array}{l}\text { an inhibitor } \\
\text { or } \\
\text { activator } \\
\text { of a } \\
\text { protein } \\
\end{array}$ & $\begin{array}{l}\text { Henderson's Dictionary of } \\
\text { Biological Terms ( } 11 \text { th ed. } \\
\text { 1995) }\end{array}$ & Clevenger \\
\hline $\begin{array}{l}\text { In re Morgan, } 87 \text { Fed. } \\
\text { Appx. 746, } 750 \text { (Fed. } \\
\text { Cir. 2004) }\end{array}$ & 2004 & a recess & $\begin{array}{l}\text { Webster's II New Riverside } \\
\text { University Dictionary (1984) }\end{array}$ & Gajarsa \\
\hline $\begin{array}{l}\text { Intergraph Corp. v. Intel } \\
\text { Corp., } 89 \text { Fed. Appx. 218, } \\
229 \text { (Fed. Cir. 2004) }\end{array}$ & 2004 & in $\mathbf{a}[\mathrm{Z}]$ & $\begin{array}{l}\text { Webster's New World } \\
\text { Dictionary (3d college ed. } \\
1988 \text { ) }\end{array}$ & Lourie \\
\hline $\begin{array}{l}\text { International Rectifier } \\
\text { Corp. v. IXYS Corp., } 361 \\
\text { F.3d 1363, 1370-71, 70 } \\
\text { U.S.P.Q.2d (BNA) 1209, } \\
1215 \text { (Fed. Cir. 2004) }\end{array}$ & 2004 & $\begin{array}{l}\text { polygonal } \\
\text { region }\end{array}$ & $\begin{array}{l}\text { Webster's Third New } \\
\text { International Dictionary } \\
\text { (1966); } \\
\text { Webster's Third New } \\
\text { International Dictionary } \\
\text { (1993) }\end{array}$ & Linn \\
\hline $\begin{array}{l}\text { International Rectifier } \\
\text { Corp. v. IXYS Corp., } 361 \\
\text { F.3d 1363. 1372, 70 } \\
\text { U.S.P.Q.2d (BNA) 1209, } \\
1216 \text { (Fed. Cir. 2004) }\end{array}$ & 2004 & $\begin{array}{l}\text { annular } \\
\text { ring }\end{array}$ & $\begin{array}{l}\text { Webster's Third New } \\
\text { International Dictionary } \\
\text { (1966) }\end{array}$ & Linn \\
\hline
\end{tabular}




\begin{tabular}{|c|c|c|c|c|}
\hline CASE & YEAR & $\begin{array}{l}\text { CLAIM } \\
\text { TERM }\end{array}$ & SOURCE(S) USED & JUDGE \\
\hline $\begin{array}{l}\text { International Rectifier } \\
\text { Corp. v. IXYS Corp., } 361 \\
\text { F.3d 1363, 1374, } 70 \\
\text { U.S.P.Q.2d (BNA) 1209, } \\
1217 \text { (Fed. Cir. 2004) }\end{array}$ & 2004 & adjoining & $\begin{array}{l}\text { Webster's Third New } \\
\text { International Dictionary } \\
\text { (1966) }\end{array}$ & Linn \\
\hline $\begin{array}{l}\text { Leoutsakos v. Coll's Hosp. } \\
\text { Pharmacy, Inc., } 98 \text { Fed. } \\
\text { Appx. 835, 838-39 (Fed. } \\
\text { Cir. 2004) }\end{array}$ & 2004 & $\begin{array}{l}\text { planar plate } \\
\text { member }\end{array}$ & $\begin{array}{l}\text { Webster's Third New } \\
\text { International Dictionary } \\
\text { (1993) }\end{array}$ & Rader \\
\hline $\begin{array}{l}\text { Linear Tech. Corp. } v . \\
\text { Impala Linear Corp., } 71 \\
\text { U.S.P.Q.2d (BNA) 1161, } \\
1165-66 \text { (Fed. Cir. 2004) }\end{array}$ & 2004 & circuit & $\begin{array}{l}\text { Dictionary of Computing } \\
\text { (4th ed. 1996); } \\
\text { Modern Dictionary of } \\
\text { Electronics ( } 7 \text { th ed. 1999) }\end{array}$ & Linn \\
\hline $\begin{array}{l}\text { Linear Tech. Corp. v. } \\
\text { Impala Linear Corp., } 71 \\
\text { U.S.P.Q.2d (BNA) 1161, } \\
1168-69 \text { (Fed. Cir. 2004) }\end{array}$ & 2004 & $\begin{array}{l}\text { simultaneou } \\
\text { sly } \\
\text { off/ [ simul } \\
\text { taneous }]\end{array}$ & $\begin{array}{l}\text { Webster's Third New } \\
\text { International Dictionary } \\
\text { (1993) }\end{array}$ & Linn \\
\hline $\begin{array}{l}\text { Microsoft Corp. v. Multi- } \\
\text { Tech Sys., Inc., } 357 \text { F.3d } \\
1340,1347 \text { n. } 3,69 \\
\text { U.S.P.Q.2d (BNA) 1815, } \\
1821 \text { n.3 (Fed. Cir. } \\
2004 \text { ) }\end{array}$ & 2004 & full duplex & $\begin{array}{l}\text { Microsoft Press Computer } \\
\text { Dictionary (1991) }\end{array}$ & Lourie \\
\hline $\begin{array}{l}\text { Microsoft Corp. v. Multi- } \\
\text { Tech Sys., Inc., 357 F.3d } \\
\text { 1340, 1352, 69 } \\
\text { U.S.P.Q.2d (BNA) 1815, } \\
1825 \text { (Fed. Cir. 2004) } \\
\end{array}$ & 2004 & headers & $\begin{array}{l}\text { Microsoft Computer } \\
\text { Dictionary (4th ed. 1999) }\end{array}$ & Lourie \\
\hline $\begin{array}{l}\text { Novartis Pharms. Corp. } v \text {. } \\
\text { Eon Labs Mfg., Inc., } 363 \\
\text { F.3d 1306, 1308-09, } 70 \\
\text { U.S.P.Q.2d (BNA) 1438, } \\
1440 \text { (Fed. Cir. 2004) }\end{array}$ & 2004 & hydrosol & $\begin{array}{l}\text { Webster's Third New } \\
\text { International Dictionary } \\
(2002)\end{array}$ & Dyk \\
\hline $\begin{array}{l}\text { Nystrom v. TREX Co., Inc., } \\
\text { 374 F.3d 1105, 1111-12, } \\
\text { 71 U.S.P.Q.2d (BNA) } \\
\text { 1241, } 1246 \text { (Fed. Cir. } \\
\text { 2004) }\end{array}$ & 2004 & board & $\begin{array}{l}\text { Webster's Third New } \\
\text { International Dictionary } \\
\text { (2002); } \\
\text { American Heritage Dictionary } \\
\text { (4th ed. 2000) }\end{array}$ & Linn \\
\hline $\begin{array}{l}\text { Nystrom v. TREX Co., Inc., } \\
\text { 374 F.3d 1105, 1115, } 71 \\
\text { U.S.P.Q.2d (BNA) 1241, } \\
1248 \text { (Fed. Cir. 2004) }\end{array}$ & 2004 & $\begin{array}{l}\text { convex top } \\
\text { surface }\end{array}$ & $\begin{array}{l}\text { American Heritage Dictionary } \\
\text { (4th ed. 2000) }\end{array}$ & Linn \\
\hline $\begin{array}{l}\text { Phillips v. AWH Comp., } \\
\text { 363 F.3d 1207, 1212, } 70 \\
\text { U.S.P.Q.2d (BNA) 1417, } \\
1420 \text { (Fed. Cir. 2004) }\end{array}$ & 2004 & $\begin{array}{l}\text { internal } \\
\text { steel baffles }\end{array}$ & $\begin{array}{l}\text { Webster's Third New } \\
\text { International Dictionary } \\
\text { (1993) }\end{array}$ & Lourie \\
\hline $\begin{array}{l}\text { SuperGuide Corp. v. } \\
\text { DirecTV Enters., Inc., } 358 \\
\text { F.3d } 870,850,69 \\
\text { U.S.P.Q.2d (BNA) 1865, } \\
1872 \text { (Fed. Cir. 2004) }\end{array}$ & 2004 & $\begin{array}{l}\text { regularly } \\
\text { received }\end{array}$ & $\begin{array}{l}\text { American Heritage Dictionary } \\
\text { (6th ed. 1976) }\end{array}$ & Prost \\
\hline
\end{tabular}




\begin{tabular}{|c|c|c|c|c|}
\hline CASE & YEAR & $\begin{array}{l}\text { CLAIM } \\
\text { TERM }\end{array}$ & SOURCE(S) USED & JUDGE \\
\hline $\begin{array}{l}\text { SuperGuide Corp. v. } \\
\text { DirecTV Enters., Inc., } 358 \\
\text { F.3d 870, 882, } 69 \\
\text { U.S.P.Q.2d (BNA) 1865, } \\
1874 \text { (Fed. Cir. 2004) }\end{array}$ & 2004 & a search on & $\begin{array}{l}\text { Webster's Third New } \\
\text { International Dictionary } \\
\text { (1993) }\end{array}$ & Prost \\
\hline $\begin{array}{l}\text { SuperGuide Corp. } v . \\
\text { DirecTV Enters., Inc., } 358 \\
\text { F.3d 870, 886, } 69 \\
\text { U.S.P.Q.2d (BNA) 1865, } \\
1877 \text { (Fed. Cir. 2004) } \\
\end{array}$ & 2004 & $\begin{array}{l}\text { at least one } \\
\text { of }[\mathrm{W}] \\
{[\mathrm{X}],[\mathrm{Y}]} \\
\text { and }[\mathrm{Z}]\end{array}$ & $\begin{array}{l}\text { Strunk \& White, The } \\
\text { Elements of Style (4th ed. } \\
2000 \text { ) }\end{array}$ & Prost \\
\hline $\begin{array}{l}\text { TI Group Auto. Sys. (N. } \\
\text { Am.), Inc. v. VDO N. Am., } \\
\text { L.L.C., 375 F.3d } 1126 \text {, } \\
1134,71 \text { U.S.P.Q.2d } \\
\text { (BNA) 1328, } 1334 \text { (Fed. } \\
\text { Cir. 2004) }\end{array}$ & 2004 & $\begin{array}{l}\text { fuel } \\
\text { reservoir }\end{array}$ & $\begin{array}{l}\text { Oxford English Dictionary } \\
\text { (2d ed. 1989); } \\
\text { Webster's Third New } \\
\text { International Dictionary } \\
(1986)\end{array}$ & Linn \\
\hline $\begin{array}{l}\text { TI Group Auto. Sys. (N. } \\
\text { Am.), Inc. v. VDO N. Am., } \\
\text { L.L.C., 375 F.3d 1126, } \\
\text { 1135-36, 71 U.S.P.Q.2d } \\
\text { (BNA) 1328, 1335-36 } \\
\text { (Fed. Cir. 2004) }\end{array}$ & 2004 & within & $\begin{array}{l}\text { Oxford English Dictionary } \\
\text { (2d ed. 1989); } \\
\text { Webster's Third New } \\
\text { International Dictionary } \\
(1986)\end{array}$ & Linn \\
\hline $\begin{array}{l}\text { TI Group Auto. Sys. (N. } \\
\text { Am.), Inc. v. VDO N. Am., } \\
\text { L.L.C., } 375 \text { F.3d } 1126 \text {, } \\
1138,71 \text { U.S.P.Q.2d } \\
\text { (BNA) 1328, } 1337 \text { (Fed. } \\
\text { Cir. 2004) }\end{array}$ & 2004 & $\begin{array}{l}\text { opening for } \\
\text { connectin } \\
\mathrm{g}\end{array}$ & $\begin{array}{l}\text { Oxford English Dictionary } \\
\text { (2d ed. 1989) }\end{array}$ & Linn \\
\hline $\begin{array}{l}\text { TI Group Auto. Sys. (N. } \\
\text { Am.), Inc. v. VDO N. Am., } \\
\text { L.L.C., 375 F.3d } 1126, \\
1138,71 \text { U.S.P.Q.2d } \\
\text { (BNA) 1328, } 1337 \text { (Fed. } \\
\text { Cir. 2004) }\end{array}$ & 2004 & $\begin{array}{l}\text { opening } \\
\text { for } \\
\text { connecting }\end{array}$ & $\begin{array}{l}\text { Webster's Third New } \\
\text { International Dictionary } \\
\text { (1986) }\end{array}$ & Linn \\
\hline $\begin{array}{l}\text { Ultratech Stepper, Inc. v. } \\
\text { ASM Lithography, Inc., } 97 \\
\text { Fed. Appx. 914, 919-20 } \\
\text { (Fed. Cir. 2004) }\end{array}$ & 2004 & $\begin{array}{l}\text { microcircuit } \\
\text { device }\end{array}$ & $\begin{array}{l}\text { Oxford Reference } \\
\text { Dictionary (1989); } \\
\text { McGraw-Hill Electronics } \\
\text { Dictionary (5th ed. 1994) }\end{array}$ & Schall \\
\hline $\begin{array}{l}\text { W.E. Hall Co., Inc. } v . \\
\text { Atlanta Corrugating, LLC, } \\
370 \text { F.3d 1343, 1350, } 71 \\
\text { U.S.P.Q.2d (BNA) 1135, } \\
1140 \text { (Fed. Cir. 2004) }\end{array}$ & 2004 & $\begin{array}{l}\text { open } \\
\text { channels }\end{array}$ & $\begin{array}{l}\text { Oxford English Dictionary } \\
\text { (2d ed. 1989) }\end{array}$ & Gajarsa \\
\hline $\begin{array}{l}\text { Zimmer, Inc. v. Howmedica } \\
\text { Osteonics Corp., } 111 \text { Fed. } \\
\text { Appx. 593, } 599 \text { (Fed. } \\
\text { Cir. 2004) }\end{array}$ & 2004 & $\begin{array}{l}\text { modular } \\
\text { prosthesis } \\
\text { system }\end{array}$ & $\begin{array}{l}\text { Webster's Third New } \\
\text { International Dictionary } \\
\text { (2002) }\end{array}$ & Dyk \\
\hline
\end{tabular}


***

HeinOnline -- 54 Am. U. L. Rev. 940 2004-2005 